IVY CASSA

\title{
NATUREZA JURÍDICA DA RESERVA MATEMÁTICA NOS PLANOS DE PREVIDÊNCIA PRIVADA ABERTA
}

Dissertação de mestrado

Orientadora: Professora Doutora Vera Helena de Mello Franco

Faculdade de Direito da Universidade de São Paulo

São Paulo

2014 


\section{IVY CASSA}

Natureza jurídica da reserva matemática nos planos de previdência privada aberta Dissertação apresentada à Comissão Julgadora da Faculdade de Direito da Universidade de São Paulo, como exigência parcial para obtenção do título de Mestre em Direito Comercial, sob a orientação da Professora Doutora Vera Helena de Mello Franco.

Aprovada em:

\section{Banca Examinadora}

1- Orientadora: Vera Helena de Mello Franco

2- Examinador (a):

3- Examinador (a): 


\section{AGRADECIMENTOS}

À Faculdade de Direito do Largo de São Francisco, por tudo que representa na história do pensamento jurídico brasileiro; por ser "onde mora a amizade e onde mora a alegria"; e porque é reconfortante retornar a essa casa que sempre tão bem me acolheu.

À minha orientadora Vera Helena de Mello Franco, por ter acreditado neste projeto; pela generosidade de ter colocado à minha disposição sua vasta bagagem de conhecimento e a sua biblioteca pessoal; pelas discussões que me fizeram refletir e amadurecer e, especialmente, pela sua enorme acessibilidade, apoio e compreensão.

À agência financiadora deste projeto (CAPES), pela bolsa de mestrado PROEX concedida, com a qual pude constituir uma coleção de livros para utilização como fonte para esta dissertação, bem como financiar um curso de especialização em "Seguros, previdência e saúde" na Universidade de Salamanca, em parceria com a Fundación Mapfre, permitindo ampliar meus horizontes a respeito da matéria.

À Fundación Mapfre, pelo seu riquíssimo acervo em seguros e previdência e, em especial, às suas bibliotecárias, pelo pronto atendimento, agilidade e disponibilidade em auxiliar.

Ao Instituto Brasileiro de Direito do Seguro - IBDS, na figura do seu presidente Ernesto Tzirulnik, por todo trabalho estimulado e desenvolvido em matéria de seguro no Brasil; pelo legado material produzido; e pela biblioteca - de dimensão única em seguros no nosso país, onde busquei as primeiras fontes para o embrião deste trabalho.

Ao Paulo Luiz de Toledo Piza, por ter me deixado "incomodada" quando me disse, no início da minha carreira, que planos de previdência privada eram investimentos informação esta que só fui capaz de processar e digerir após anos de estudo sobre o assunto. 
À Associação Internacional do Direito do Seguro - AIDA, em especial aos meus colegas do Grupo Nacional de Trabalho de Previdência Privada, de Seguro de Pessoas e de Direito Econômico, pelas ricas discussões que tivemos ao longo dos últimos anos, as quais contribuíram direta ou indiretamente para o amadurecimento das minhas reflexões sobre o tema objeto deste trabalho.

Aos professores Haroldo Malheiros Duclerc Verçosa e Marcos Paulo de Almeida Sales, pelos ensinamentos nas aulas, pelas preciosas observações no exame de qualificação e, em especial a este último, por ter chamado a minha atenção ao longo do curso para eu não perder o "olhar jurídico" sobre as questões que procurava investigar.

Aos meus companheiros do mestrado, em especial à Adriana e à Angélica, com quem dividi momentos de estudo, dúvidas, ideias, alegrias e cansaço. Particularmente, à Taimi, que, além disso, esteve ao meu lado o tempo todo, e ainda auxiliou na revisão desta dissertação.

Aos meus amigos, que contribuíram e ajudaram das mais variadas formas, nomeadamente à Heloisa, cujo suporte nas questões pessoais foi essencial para que eu obtivesse energia e não abdicasse deste sonho.

Ao Paulo Sogayar, pelas discussões e provocações sobre o estudo da previdência privada e, particularmente, por ter cedido seu acervo de livros para consulta.

Aos meus pais, pelo apoio, pela torcida, mas, sobretudo, pela compreensão por todos os momentos em que estive ausente durante as fases críticas deste projeto.

Ao Pedro, porque observar a sua força tornou-me mais forte também. 
A natureza impõe limites. Não importa quão sofisticado ou rudimentar, nenhum agrupamento humano sobreviverá por muito tempo se não for capaz de transferir uma quantidade mínima de recursos do presente para o futuro.

(Eduardo Gianetti) 


\section{RESUMO}

O presente trabalho tem por objetivo o estudo da natureza jurídica do "saldo de conta" (aqui designado como "reserva matemática") de que o participante é titular durante a fase de acumulação de um plano de Contribuição Variável de entidade aberta de previdência privada. O tema foi desenvolvido à luz do Direito do Seguro, por meio do confronto dos elementos jurídicos e técnicos dos contratos de seguros privados com os dos contratos previdenciários privados, e ainda levando em consideração a evolução dos produtos de previdência privada e seguros no contexto do bancassurance. Dada a escassez de literatura nacional específica sobre o tema, o estudo foi realizado com o suporte do Direito Comparado.

Palavras-chave: Reserva matemática; Previdência privada aberta; Planos de Contribuição Variável; Bancassurance; Contrato de seguro. 


\begin{abstract}
The present work aims to study the legal nature of "account balance" (herein referred as "mathematical reserves") that the participant holds during the accumulation phase of a variable contribution retirement plan. The subject was developed according to Insurance Law, by confronting the legal and technical elements of private insurance contracts with retirement plan contracts, and considering the evolution of retirement plans and insurance products in the context of bancassurance. Given the lack of specific literature on this subject in Brazil, this study was conducted with the support of Comparative Law.
\end{abstract}

Keywords: Mathematics reserve; Retirement plan; Variable Contribution Plans; Bancassurance; Insurance contract. 


\section{LISTA DE ABREVIATURAS E SIGLAS}

BD - Plano de Benefício Definido

CC02 - Código Civil de 2002

CC16 - Código Civil de 1916

CD - Plano de Contribuição Definida

$\mathrm{CF}$ - Constituição Federal Brasileira

CMN - Conselho Monetário Nacional

CNSP - Conselho Nacional dos Seguros Privados

CV - Plano de Contribuição Variável

DL - Decreto-Lei

FAPI - Fundo de Aposentadoria Programada Individual

FGB - Fundo Garantidor de Benefícios

FIE - Fundo de Investimento Especialmente Constituído

IBGE - Instituto Brasileiro de Geografia e Estatística

INSS - Instituto Nacional do Seguro Social

LC - Lei Complementar

PGBL - Plano Gerador de Benefício Livre

RGPS - Regime Geral de Previdência Social

RPPS - Regime Próprio de Previdência Social

SUSEP - Superintendência de Seguros Privados

VGBL - Vida Gerador de Benefício Livre 


\section{LISTA DE GRÁFICOS}

Gráfico 1 - Evolução da carteira de investimentos das entidades abertas

Gráfico 2 - Cota de distribuição de bancasseguros nos mercados selecionados

Gráfico 3 - Ranking de seguros - total sem VGBL

Gráfico 4 - Ranking de seguros - Pessoas (sem VGBL)

Gráfico 5 - Ranking de seguros -VGBL

Gráfico 6 - Ranking de seguros - Previdência

Gráfico 7 - Coeficiente de penetração do mercado de seguros e previdência privada aberta 


\section{SUMÁRIO}

\section{INTRODUÇÃO}

\section{CAPÍTULO I - PANORAMA DA PREVIDÊNCIA PRIVADA}

1.1- Evolução da previdência

1.2- Previdência social no Brasil

1.3- Surgimento da previdência privada no Brasil

1.4- Desenvolvimento da previdência privada após o Plano Real

1.5- Principais características da previdência privada

1.5-1. Caráter privado

1.5-2. Complementaridade

1.5-3. Autonomia

1.5-4. Facultatividade

1.5-5. Constituição de reservas

1.5-5.1. Provisão técnica

1.5.5.2. Reserva matemática

1.6. Modalidades de planos de previdência privada

1.6.1. Planos de benefício definido (BD)

1.6.2. Planos de contribuição definida (CD)

1.6.3. Planos de contribuição variável (CV)

1.7. Tipos de planos oferecidos no mercado brasileiro

1.7.1. PGBL e VGBL

\subsubsection{FAPI}

\section{CAPÍTULO II - BANCASSURANCE}

2.1. Preliminarmente

2.2. Conceito de bancassurance e breve histórico

2.3. Atividade financeira

2.4. "Produtos" ou "serviços financeiros"

2.5. Produtos 
2.6. Bancassurance no Brasil

\section{CAPÍTULO III - CARACTERIZAÇÃo DOS SEGUROS PRIVADOS}

3.1. Da solidariedade à sociedade de risco

3.2. Breve história do seguro

3.3. O surgimento do seguro privado no Brasil

3.4. Arcabouço jurídico

3.5. Seguro social e seguro privado

3.5.1. Forma de filiação

3.5.2. Financiamento

3.5.3. Instrumentalização da relação

3.5.4. Tipos de riscos cobertos

3.5.5. Solidariedade e mutualismo

3.5.6. Administração

3.6. A previdência privada não é um seguro social

3.7. Seguros de danos e seguros de pessoas

3.7.1. Classificação dos seguros de pessoas

3.8. Elementos do contrato de seguro

3.8.1. Empresarialidade

3.8.1.1. Vantagens da empresarialidade para o seguro

3.8.1.2. Empresarialidade no Brasil

3.8.1.3. Objeto social específico das seguradoras

3.8.1.4. Prévia autorização para funcionamento e demais exigências

3.8.2. Mutualismo

3.8.3. Garantia

3.8.4. Interesse

3.8.5. Prêmio

3.8.6. Risco

3.8.6.1. Risco especulativo e risco puro 
CAPÍTULO IV - CONFRONTO DOS ELEMENTOS DO CONTRATO DE SEGURO COM A PREVIDÊNCIA PRIVADA

4.1. Empresarialidade - entidades de previdência privada

4.1.1. Restrição da atividade a pessoas jurídicas

4.1.2. Exigências às entidades de previdência privada

4.2. Mutualismo

4.3. Garantia

4.4. Interesse

4.5. Prêmio e contribuição

4.6. Risco - risco puro e risco especulativo

CAPÍTULO V - CONSIDERAÇÕES FINAIS

REFERÊNCIAS 


\section{NOTA INTRODUTÓRIA SOBRE O TÍTULO DESTE TRABALHO}

Adotou-se para esta dissertação a nomenclatura "reserva matemática" por se ter entendido ser a expressão mais adequada ao "saldo de conta" que o participante detém junto à entidade aberta de previdência privada, durante a fase de diferimento, em um plano de acumulação ${ }^{1}$ que não conjugue cobertura de risco $^{2}$, ou no qual a cobertura de risco não seja um elemento essencial da operação e, sim, o seu caráter de instrumento financeiro.

Reconhecemos que, do ponto de vista da atuária, existem inúmeras provisões ${ }^{3}$ e reservas no âmbito das entidades de previdência privada e seguradoras. Nosso objetivo neste trabalho não é fazer uma abordagem técnica ou atuarial do instituto, mas analisar a natureza jurídica desse "saldo de conta" de titularidade do participante.

Optamos por nos servir, portanto, de uma expressão que não é do Direito, embora entendamos que o seu conceito, sob a ótica da atuária, seja bem mais amplo. Fizemos isso por crer que, caso o título deste trabalho fosse "a natureza jurídica da previdência privada", a ideia transmitida seria muito vasta. A afirmação esteia-se no fato de existir a previdência privada das entidades fechadas e das abertas e, dentro destas últimas, terem lugar os PGBLs, VGBLs, FAPIs, planos de pecúlio, planos tradicionais (FGBs), dentre tantos outros, cada qual com duas fases distintas ${ }^{4}$ e características bem definidas.

Considerando que nosso escopo é tratar exclusivamente da natureza jurídica desse "saldo de conta" durante a fase de acumulação, e apenas com relação aos planos de Contribuição Variável das entidades abertas, justifica-se o critério acatado.

Por essa razão, iniciamos nossa exposição com as devidas apologias aos atuários, pela apropriação de expressão não recorrente da área jurídica, por apreendermos que, com

\footnotetext{
${ }^{1}$ V.g. PGBL e VGBL.

${ }^{2}$ V.g. invalidez, morte, renda vitalícia etc.

${ }^{3}$ V.g. Provisão matemática de benefícios a conceder, provisão matemática de benefícios concedidos, provisão de oscilação financeira, provisão técnica de excedentes financeiros, provisão de sinistros a liquidar, provisão para insuficiência de prêmios, dentre outros. (neste sentido: Cristina Cantanhede Amarante Mano; Paulo Pereira Ferreira. Aspectos Atuariais e Contábeis das Provisões Técnicas. Rio de Janeiro: Funenseg, 2009)

${ }^{4}$ Acumulação (ou diferimento) e recebimento de benefício.
} 
o seu uso, será mais fácil compreender o verdadeiro sentido do instituto que pretendemos investigar. 


\section{INTRODUÇÃO}

A palavra "previdência" advém do latim, do vocábulo pre videre, que significa "ver antecipadamente", "precaver-se", "calcular", "pressupor". Quando se menciona a previdência, de maneira abrangente, remete-se ao sentido de proteção contra riscos capazes de atingir o ser humano nos seus mais variados ciclos da vida, em especial na velhice.

Pode ser definida como "termo que determina uma das características básicas de qualquer seguro, ou seja, proteção das pessoas contra danos e perdas que possam no futuro atingir seu patrimônio ou a si mesmas" ${ }^{\text {. }}$.

Para Pedro Alvim ${ }^{7}$, é uma atitude permanente de vigilância, um dos privilégios do espírito humano. A previdência, segundo o autor, seria a fonte de inspiração de todos os processos imaginados para prevenir ou suavizar os efeitos negativos do risco ao patrimônio, à saúde ou à própria vida.

O ser humano, ao longo da sua trajetória, adquiriu novos conhecimentos que lhe permitiram até mesmo prolongar sua existência ${ }^{8}$. Contudo, assim como seus antepassados de dezenas de milhares de anos, o homem permanece sujeito a riscos, necessitando de proteção e precavendo-se contra situações adversas, no sentido mais genuíno da palavra previdência.

Há registros de que os homens das cavernas, em certa altura, passaram a estocar alimentos para os períodos de frio. Renata Barbosa Dionysio e Fatima Ventura Pereira

\footnotetext{
${ }^{5}$ Definições citadas por Affonso Almiro. Teoria do Direito Previdenciário brasileiro e bibliografia previdenciária brasileira. Rio de Janeiro: IBDP, 1984, p. 4.

${ }^{6}$ DEL FIORI, Alexandre. Dicionário de seguros. São Paulo: Manuais Técnicos de Seguros, 1996, p. 45.

${ }^{7}$ ALVIM, Pedro. $O$ contrato de seguro. $3^{\mathrm{a}}$ ed. Rio de Janeiro: Forense, 2001, p. 1.

${ }^{8}$ Estima-se que a expectativa de vida do homem pré-histórico era de 30 anos; em Roma e Grécia antigas (de 500 a.C. a 500 d.C.), era de 35; durante o período medieval, variou de 48 a 38 (a queda ocorreu, principalmente, devido à peste negra, que dizimou cerca de 25 milhões de pessoas só na Europa); de $1850 \mathrm{a}$ 1900 houve nova redução na expectativa, para 40 anos, por conta de doenças como a febre tifóide e a tuberculose). Foi só a partir do século XX que se passou a considerar uma expectativa de vida superior a 70 anos. Sobre este tema, vide Aswath Damodaran. Gestão estratégica do risco. Porto Alegre: Bookman, 2003, p. 21 .
} 
Meirelles ${ }^{9}$ relatam que, no Período Paleolítico, o homem nômade caçava e coletava alimentos para satisfazer sua fome imediata. Entretanto, segundo as autoras, mesmo nessa época tão rudimentar, ele já tinha um “instinto previdente”, pois armazenava alimentos na parte mais fria e escura das cavernas para os dias em que a caça não era boa, ou os alimentos não eram abundantes. ${ }^{10}$

Com o desenrolar da evolução, a previdência adquiriu outros contornos: na sua origem, resvalou no contrato de seguro, mas se enveredou para o amparo exclusivo contra os riscos próprios da vida em sociedade e relacionados com a renda do trabalhador. Principiou nos ideais de solidariedade e caridade, nos braços da igreja, e evoluiu para uma proteção institucionalizada, no seio do Estado, que passou a chamar para si tal responsabilidade.

Entretanto, foi no último século que o receio com relação ao amanhã se agigantou $^{11}$, eis que o homem nunca portou uma longevidade como a que tem agora.

E se a duração da vida for maior do que os recursos financeiros acumulados ao longo da existência, como garantir o sustento?

O envelhecimento populacional, que por um lado foi uma conquista do ser humano, por outro se revela um obstáculo a ser enfrentado. É preciso encontrar mecanismos de financiamento para a população idosa se manter, talvez durante décadas, em condições dignas, muitas vezes sem trabalhar (aposentada), no momento da vida em

\footnotetext{
9 Conservação de alimentos. Disponível em <http://web.ccead.pucrio.br/condigital/mvsl/Sala\%20de\%20Leitura/conteudos/SL_conservacao_de_alimentos.pdf $>, \quad$ acesso em 02/01/14.

${ }^{10}$ No mesmo sentido é a doutrina de Jean-Louis Flandrin e Massimo Montanari (História da Alimentação Os Tempos Modernos. São Paulo: Estação Liberdade, 1998).

${ }^{11}$ Estelle James alerta "Ao longo dos próximos 35 anos, a proporção da população mundial acima de 60 anos praticamente dobrará, de $9 \%$ para $16 \%$. Devido aos rápidos aumentos na expectativa de vida e aos declínios das taxas de fertilidade, as populações estão envelhecendo muito mais rapidamente nos países em desenvolvimento do que ocorreu nos países industriais. À medida que as pessoas jovens em idade de trabalho produtivo se aproximarem da aposentadoria - por volta do ano 2013 -, $80 \%$ da população idosa do mundo viverão no que hoje são países em desenvolvimento. Esses países estarão mudando de sistemas previdenciários informais para sistemas formais e, dado o rápido ritmo do processo de envelhecimento, é imprescindível que eles efetuem a transição acertadamente desde o início. Ao mesmo tempo, os países industrializados estão procurando reformar seus atuais sistemas de modo a torná-los mais sustentáveis e menos caros." (Novos sistemas previdenciários: experiência, evidências e questões pendentes in A Economia Política da Reforma da Previdência. 1998, p. $9 . \quad$ Disponível em <http://www.previdencia.gov.br/arquivos/office/3_081014-111356-651.pdf>, acesso em 16/12/13)
} 
que os gastos com a saúde crescem significativamente ${ }^{12}$, e sem ter de depender de recursos de terceiros.

Essa preocupação com a longevidade traduz uma nova etapa do desenvolvimento da previdência ${ }^{13}$, caracterizada pela busca de instrumentos financeiros que possam complementar o regime da previdência social, o qual vem demonstrando deficiências para atender a população ${ }^{14}$.

Dentre as opções orientadas para o longo prazo, o indivíduo pode escolher entre guardar o dinheiro em espécie em um cofre, investir em uma caderneta de poupança, comprar um imóvel, contratar um seguro com cobertura por sobrevivência ou um plano previdenciário privado, por exemplo.

Atualmente, muitos desses instrumentos de acumulação de recursos vêm se aproximando por conta do fenômeno do bancassurance, que é a comercialização de "produtos"15 de seguros ou previdência privada pelo canal bancário, juntamente com outros produtos financeiros, em um processo no qual se observa alguma padronização entre tais veículos, bem como a atenuação dos seus limites.

12 Sobre este assunto, vide Envelhecimento e gastos com saúde. Disponível em: <http://www.iess.org.br/html/ano1n5.pdf >. Acesso em: 09/10/13.

13 A OCDE (Organização para a Cooperação e Desenvolvimento Econômico) destacou no documento Private Pensions and Policy Responses to the Crisis, outubro de 2009 a importância dos planos de previdência privada, à medida que o envelhecimento populacional tem conduzido muitos países da OCDE a promover reformas em seus sistemas públicos, no sentido de reduzir as aposentadorias públicas e incrementar $\begin{array}{llllll}\text { a participação } & \text { dos } & \text { sistemas } & \text { privados. } & \text { (disponível } & \mathrm{em}\end{array}$ <http://www.previdencia.gov.br//arquivos/office/3_090714-173205-002.pdf>. Acesso em 27/11/13)

${ }^{14}$ A questão do déficit da previdência pública é controversa. Enquanto, por um lado, são publicados frequentemente em jornais de grande circulação dados que revelam desequilíbrio entre as contribuições e o pagamento de benefícios, há correntes de economistas que defendem que o déficit da previdência seria um "mito". A respeito do alegado déficit: Déficit da Previdência ficou em $R \$ 42,3$ bilhões no ano passado [2012]. (SARRES, Carolina) Disponível em: <http://agenciabrasil.ebc.com.br/noticia/2013-01-30/deficit-daprevidencia-ficou-em-r-423-bilhoes-no-ano-passado> Acesso em: 01/07/13. Previdência registra em janeiro maior déficit para o mês desde 2009. (MARCHESINI, Lucas; RESENDE, Thiago) Disponível em: $<$ http://www.valor.com.br/brasil/3042202/previdencia-registra-em-janeiro-maior-deficit-para-o-mes-desde2009\#ixzz2YrrCFimI>. Acesso em: 01/07/13. Sobre o "mito do déficit": Déficit da Previdência é um mito, diz presidente da Anfip (TÔRRES, Renata) Disponível em: <http://www2.camara.leg.br/camaranoticias/noticias/ADMINISTRACAO-PUBLICA/201168-DEFICIT-DAPREVIDENCIA-E-UM-MITO,-DIZ-PRESIDENTE-DA-ANFIP.html>. Acesso em: 02/07/2013. Falacioso déficit da previdência social. (VELLOSO, Andrei Pitten) Disponível em: <http://www.sindifisconacionalsp.org.br/UserFiles/File/Mat\%C3\%A9rias\%20de\%20Jornais/artigo_Previdencia.pdf>. Acesso em: 05/07/13.

${ }^{15}$ Adotou-se para este trabalho a expressão "produtos" para referir-se aos planos de seguros, de previdência privada e aos instrumentos financeiros de acumulação de poupança, embora se trate de expressão mais usual na esfera financeira do que na jurídica. 
O tema escolhido para esta dissertação escorou-se no estágio evolutivo atingido pela previdência ao longo da sua existência, por ser de fundamental importância assimilar seu conceito e os ciclos ocorridos, a fim de que se possa compreender o papel da previdência privada na atualidade. 


\section{A ESCOLHA DA PREVIDÊNCIA PRIVADA COMO TEMA DESTE TRABALHO}

A previdência privada consiste em relevante mecanismo de acumulação de recursos para necessidades futuras, que adquiriu especial destaque nos últimos anos por conta de fatores demográficos ${ }^{16} \mathrm{e}$, especificamente no Brasil, pela conjuntura econômica que vivemos nas últimas décadas ${ }^{17}$.

Além da sua importância como instrumento de proteção, a previdência privada também se sobressai economicamente porque as entidades que a operam são captadoras de poupança $\operatorname{popular}^{18}$ e desempenham importantíssimo papel como investidoras

16 Como destaca Francine Leite: “A população idosa brasileira tem aumentado consideravelmente e representa atualmente cerca de $10 \%$ da população total - em 1980 essa proporção era de $6 \%$ (IBGE, 2008). O processo de envelhecimento no Brasil tem sido mais acelerado do que em outros países, resultado da rápida mudança tanto da taxa de fecundidade quanto da expectativa de vida." (Envelhecimento populacional e a composição etária de beneficiários de planos de saúde. Disponível em: <http://www.iess.org.br/html/TDIESS00422011EnvelhecimentoFE.pdf>. Acesso em: 01/09/13)

Conforme dados divulgados pelo Instituto Brasileiro de Geografia e Estatística (IBGE), a expectativa de vida do brasileiro aumentou em 11 anos, comparando a década de 80 com o ano de 2010 (em 2010, a expectativa de vida ao nascer do brasileiro era de 73 anos). (DUTRA, Bruno. Aumento na expectativa de vida do brasileiro preocupa Previdência. Disponível em: <http://economia.ig.com.br/financas/aposentadoria/201308-05/aumento-na-expectativa-de-vida-do-brasileiro-preocupa-previdencia.html>. Acesso em: 02/09/13)

Fernando Pimentel afirma que, no Brasil, atualmente, mais de 30 mil pessoas já são centenárias, e que em 2050 haverá mais de dois bilhões de pessoas no mundo com mais de 100 anos. (O papel social dos fundos de pensão (in Papel dos fundos de pensão na formação da economia brasileira - Capitalismo Social. São Paulo: ABRAPP/ICSS/SINDAP, 2007, p. 101)

Dentre os fatores demográficos merece destaque a presença efetiva da mulher no mercado de trabalho, que impacta na redução do número de filhos - Segundo dados divulgados pelo IBGE, os casais brasileiros registravam, em média, 1,9 filhos em 2010, enquanto essa marca superava os 6,1 filhos na década de 1940. (Brasileira tem um terço dos filhos da década de 1940, Disponível em: <http://noticias.r7.com/brasil/noticias/brasileira-tem-um-terco-dos-filhos-da-decada-de-1940-

20121017.html>. Acesso em: 06/09/2013.)

${ }_{17}$ Notadamente pela estabilidade econômica propiciada pelo Plano Real, que permitiu o planejamento financeiro de longo prazo.

18 “A geração de um volume mínimo de poupança interna de forma continuada é um dos principais fatores de sustentabilidade do crescimento de uma economia. Esta poupança viabiliza os investimentos, que são canalizados ao setor produtivo por meio do sistema financeiro. Nesse contexto, devido à magnitude das somas administradas, os investidores institucionais, agrupados em fundos mútuos de investimentos, seguradoras e entidades fechadas de previdência privada, desempenham importante papel na formação de poupança interna." (AMARAL, Hudson Fernandes et al . Fundos de pensão como formadores de poupança interna: uma alternativa para o financiamento da atividade econômica. Revista de Administração Contemporânea, $\quad$ v. $\quad 8, \quad \mathrm{n}^{\mathrm{o}} \quad 2$. Curitiba, jun/2004. Disponível em: <http://www.scielo.br/scielo.php?script=sci_arttext\&pid=S1415-65552004000200008\&lng=pt\&nrm=iso>. Acesso em 07/09/13) 
institucionais, uma vez que os recursos de suas reservas são alocados em setores estratégicos de nossa economia ${ }^{19}$, fomentando o desenvolvimento do país.

Do ponto de vista jurídico, a previdência privada é relativamente jovem, pois a primeira norma a tratar especificamente do assunto foi promulgada em 1977 - lei $n^{\circ} 6435^{20}$. Ela somente foi formalmente incluída em nossa Constituição Federal em 1998, com a inserção, por meio da Emenda Constitucional n 20, de artigo específico que a descreveu $\left(\right.$ art. 202) ${ }^{21}$. Atualmente, o diploma legal que regulamenta a matéria e revogou a legislação de 1977 é a Lei Complementar n 109, publicada em 29 de maio de 2001.

Logo, pode-se afirmar que o tema escolhido para objeto desta dissertação é economicamente relevante, atual e, sob a ótica do Direito, de certa forma recente. A par disto, a referida legislação de 2001 apresenta ainda temas pendentes de regulamentação ${ }^{22}$ e o conhecimento acerca da previdência privada no Brasil é relativamente escasso do ponto de vista jurídico, especialmente quando comparada nossa produção acadêmica com a de outros países, notadamente da Europa Ocidental.

\footnotetext{
19 "A Previdência Privada é hoje o maior investidor institucional do país. Seus ativos financeiros estão a serviço da economia nacional, fortalecendo as atividades produtivas e servindo à política econômica, uma vez que suas aplicações são direcionadas pelos órgãos governamentais." (CANUTO, Alessandra Mihailidou; FERNANDES, Maria Fernanda Otero. O crescimento da previdência privada aberta face à crise da previdência social. Disponível em: $\langle$ http://www.mackenzie.br/fileadmin/Graduacao/CCSA/Publicacoes/Jovens_Pesquisadores/02/2_2_09.pdf〉. Acesso em 10/07/2013.)

Neste mesmo sentido: "As Entidades Fechadas de Previdência Privada (EFPP) e Companhias Seguradoras são investidores institucionais extremamente importantes para o funcionamento do mercado financeiro. Como possuem obrigações com longo prazo de exigibilidade, essas instituições podem investir em ativos com maturidade mais longa. Os Bancos Comerciais e de Investimento, tradicionalmente, não possuem essa mesma flexibilidade. Esse aspecto, acrescido do elevado montante envolvido, faz com que esses investidores institucionais tenham papel relevante no desenvolvimento do mercado financeiro, sendo agentes relevantes do financiamento de novas oportunidades de negócio." (LOPES, Alexsandro Broedel; FURTADO, Cláudio Vilar. Private equity na carteira de investimentos das entidades de previdência privada In Revista de Contabilidade e Finanças - USP - Especial Atuária, São Paulo, v. 17, dez. 2006. Disponível em: $<$ http://www.scielo.br/scielo.php?script=sci_arttext\&pid=S1519-70772006000500009\&lng=pt\&nrm=iso>. Acesso em 02/09/13)

${ }^{20}$ Embora as entidades de previdência privada já existissem no Brasil há mais de 150 anos. Manuel Soares Póvoas pontua que a instituição do sistema legal por meio da lei $n^{\circ}$ 6435/77 correspondeu a uma necessidade disciplinadora, "pois a liberdade com que se atuava nesse domínio, sobretudo por parte de alguns responsáveis pelas sociedades mútuas abertas, ameaçava acabar, como de resto vinha acontecendo, com as expectativas dos respectivos associados". (Previdência privada - Filosofia, Fundamentos Técnicos, Conceituação Jurídica. $2^{\mathrm{a}}$ Ed. São Paulo: Quartier Latin, 2007, p. 34)

${ }^{21} \mathrm{O}$ texto Original da $\mathrm{CF} / 88$, como critica Daniel Pulino "referia-se textualmente à previdência privada, a rigor, em apenas três dispositivos (art. 21, VIII, 192, II e 201, $\S 8^{\circ}$ ), e ainda assim o fazia quase se passagem, de forma bastante discreta, se comparada ao texto em vigor." (grifos do autor) (PULINO, Daniel. Previdência Complementar - Natureza jurídico-constitucional e seu desenvolvimento pelas Entidades Fechadas. São Paulo: Conceito Editorial, 2011, p. 98)

${ }^{22}$ V.g. regulamentação do resseguro no âmbito da previdência privada (art. 11).
} 
Ademais, a parca produção doutrinária nacional existente, quase na sua totalidade, restringiu-se a abordar o assunto sob o ângulo do Direito da Seguridade Social ${ }^{23}$, quase nunca avaliando a previdência privada como um produto financeiro ou securitário.

Por essa razão, este trabalho representa um desafio também pelo enfoque peculiar (em nosso país) adotado para sua investigação: sob a ótica do Direito Comercial, dentro da linha de pesquisa de Direito do Seguro ${ }^{24}$.

Outrossim, a matéria é ao mesmo tempo instigante e tem diversas implicações devido, dentre outros fatores:

(i) ao caráter eminentemente técnico da linguagem de seus normativos e instrumentos contratuais;

(ii) à fragmentação da legislação e regulamentação, que conta com um "emaranhado" de normas das mais variadas naturezas ${ }^{25}$, dificultando o estudo e a compreensão global do instituto;

(iii) ao fato de ser uma atividade que necessita do suporte de outras ciências como, por exemplo, finanças, estatística e atuária;

\footnotetext{
${ }^{23}$ Não se pode ignorar, contudo, que há alguma conexão entre a previdência privada e a seguridade social, à medida que a primeira é um regime complementar à segunda. Nas palavras de Tapia Hermida: "O direito do seguro privado e o direto da seguridade social não são compartimentos isolados, mas sim conjuntos normativos bem diferenciados que, contudo e do ponto de vista de suas funções econômicas, aparecem como vasos comunicantes, pois é evidente que, à vista de uma exigência de proteção social dada, a parte não coberta pela seguridade social pública poderá ser atendida por mecanismos típicos regulados no direito do seguro privado." (Tradução livre) "El derecho del seguro privado y el derecho de la seguridad social no son compartimentos estancos, sino que son conjuntos normativos bien diferenciados que, sin embargo y desde el punto de vista de sus funciones económicas, aparecen como vasos comunicantes puesto que es evidente que, a la vista de una exigencia de protección social dada, la parte no cubierta por la seguridad social pública podrá ser atendida por mecanismos típicos regulados en el derecho del seguro privado." (Manual de Derecho de Seguros y Fondos de Pensiones. Navarra: Arazandi, 2006, p. 31)

${ }^{24} \mathrm{O}$ direito do seguro centra-se nas relações jurídicas que a seguradora mantém, em dois aspectos: (i) relações jurídicas internas, mediante a fixação do estatuto jurídico da seguradora e dos sujeitos que com ela colaboram; e (ii) relações jurídicas externas, com os tomadores de seguros, segurados, beneficiários, terceiros prejudicados etc. Sobre a tradicional dicotomia entre direito privado e direito público, Silvio Venosa esclarece que "as características do contrato de seguro e o campo securitário em geral integram unidade jurídica que extravasa o campo exclusivamente do direito privado, requerendo conhecimentos próprios de verdadeira especialidade. Cuida-se de instituto que pertence ao denominado direito social, com acentuada intervenção estatal e dirigismo contratual, categoria que suplanta a tradicional dicotomia romana dos direitos públicos e privados". (Direito Civil: contratos em espécie, 13. ed. São Paulo: Atlas, 2013, p. 393)

${ }^{25}$ V.g. legislação federal (Poder Legislativo), Circulares, Instruções Normativas, Resoluções, Pareceres, Atos Interpretativos (Poder Executivo).
} 
(iv) à complexidade envolvendo sua relação jurídica, por ser um contrato celebrado em massa ${ }^{26}$, de longa duração ${ }^{27}$, tratando de compromissos intergeracionais, envolvendo diversos agentes (participantes, assistidos, entidades, administradores de ativos e passivos); e

(v) ao aspecto de basear-se na captação de poupança popular, requerendo a vigilância do Estado, por meio dos seus órgãos regulador (CNSP) e fiscalizador (Susep), os quais zelam continuamente pelo equilíbrio do sistema e pela proteção dos direitos dos participantes.

Além de tudo, desbravar a previdência privada é tarefa um tanto árida por haver pouca disseminação da educação previdenciária. Primeiramente, porque apenas nas últimas décadas a população brasileira passou a ter a possibilidade de se planejar financeiramente com visão de longo prazo e, portanto, não desenvolveu ainda uma sólida cultura de previdência, como já cristalizada em muitos países da Europa Ocidental, por exemplo. Ademais, porque os próprios operadores do sistema, em regra geral, não tiveram treinamento adequado, por não ser a previdência privada disciplina comum nas universidades (nem mesmo na faculdade de Direito) e haver poucos cursos de formação disponíveis no mercado brasileiro. Os profissionais que atuam na área quase sempre aprenderam a especialidade na sua rotina, desprovidos de maiores reflexões científicas sobre o tema.

É esta lacuna entre o lado acadêmico e a vivência prática que talvez constitua o maior obstáculo a ser superado, e também o que explica o assunto ser tão atraente para seus estudiosos.

\footnotetext{
${ }^{26}$ Haroldo Malheiros Duclerc Verçosa, apoiado na doutrina de Vincenzo Roppo (Il Contratto, Milão: Giuffrè, 2001, p. 42) explica que "os contratos da moderna economia de massa são predispostos de forma unilateral pelo empresário, significando que o texto contratual não nasce de uma tratativa entre a empresa $e$ seu cliente, na qual este possa fazer valer seus próprios interesses. (Curso de Direito Comercial. V. 4, T. I Fundamentos da Teoria Geral dos Contratos. São Paulo: Malheiros, 2011, p. 156)

${ }^{27}$ Conforme a doutrina de Ronaldo Porto Macedo Junior, os contratos previdenciários são relacionais, ou seja, que se prolongam no tempo. (Qualificação jurídica dos fundos de previdência in Anais do II Fórum de Direito do Seguro “José Sollero Filho”. São Paulo: IBDS e Manuais Técnicos de Seguros, 2002)
} 


\section{DELIMITAÇÃO DA PESQUISA}

Embora a previdência privada seja operada por entidades que tanto podem ser abertas $^{28}$ como fechadas $^{29}$, cada qual constituindo um universo bem distinto e rico em peculiaridades, este trabalho restringiu-se à análise dos planos de benefícios das entidades ditas "abertas".

Dada a relativa proximidade de características entre o mercado segurador e de previdência privada aberta, inclusive no que toca à sua subordinação ao Ministério da Fazenda e à mesma sujeição ao órgão regulador (CNSP) e fiscalizador (Susep), foi possível desenvolver esta pesquisa à luz do Direito do Seguro.

Com tantos temas por serem desvendados nesta vasta seara, um em especial despertou atenção: a natureza jurídica da reserva matemática dos planos de previdência privada. Contudo, como a expressão "previdência privada" é bastante abrangente e pode se referir a diversos tipos de "produtos" e modelos de planos, com características bem diferentes entre si, optamos por restringir este estudo à natureza jurídica da reserva matemática dos planos de $\mathrm{CV}^{30}$, afastando, desde já, os aspectos referentes aos planos nos quais predominam as coberturas de risco ou os elementos atuariais ${ }^{31}$.

\footnotetext{
${ }^{28}$ Conforme o art. 36 da LC 109/01, “As entidades abertas são constituídas unicamente sob a forma de sociedades anônimas e têm por objetivo instituir e operar planos de benefícios de caráter previdenciário concedidos em forma de renda continuada ou pagamento único, acessíveis a quaisquer pessoas físicas." A nomenclatura "abertas", portanto, diz respeito à possibilidade de qualquer pessoa física ter acesso aos seus planos, com exceção dos planos coletivos cujo acesso é restrito às pessoas que tenham vínculo com o instituidor ou averbador do plano.

${ }^{29}$ Em contraste com as entidades abertas, o art. 31 da LC 109/01 definiu as entidades fechadas (também conhecidas como "fundos de pensão") como "aquelas acessíveis, na forma regulamentada pelo órgão regulador e fiscalizador, exclusivamente: I - aos empregados de uma empresa ou grupo de empresas e aos servidores da União, dos Estados, do Distrito Federal e dos Municípios, entes denominados patrocinadores; e II - aos associados ou membros de pessoas jurídicas de caráter profissional, classista ou setorial, denominadas instituidores." A expressão "fechadas", assim, refere-se à característica de tais entidades serem restritas às pessoas que detêm o vínculo referido nos incisos I e II do art. 31.

${ }^{30}$ V.g. PGBL, VGBL e FAPI. A escolha pelos planos CV está relacionada com a utilidade que se pretende para esta dissertação, considerando que o mercado de previdência privada aberta brasileiro é dominado quase que na sua totalidade por planos de VGBL e PGBL, como veremos a seguir.

${ }^{31}$ Como ocorre nos planos de previdência privada do tipo pecúlio, por exemplo.
} 
Desvendar a natureza jurídica da reserva matemática é uma tarefa que requer cuidado e precisão, especialmente porque as atividades de previdência privada, seguros, investimentos e outros produtos financeiros vêm se mesclando cada vez mais no que se denomina bancassurance. Nessa miscigenação de produtos, na maioria das vezes comercializados no mesmo "balcão"32, é imperioso definir e delimitar os atributos específicos de cada um, sob pena de desnaturarmos um produto pela confusão com as características de outro.

Se a reserva matemática dos planos de contribuição variável $(\mathrm{CV})$ da previdência privada aberta tiver natureza de seguro, diversos princípios ${ }^{33}$ deste instituto (tais como as normas de indicação de beneficiários), dever-lhe-ão ser aplicados. Em contraposição, se for compreendida como produto financeiro, daí outras tantas consequências sobrevirão, tal como a própria questão da indicação do beneficiário que ficaria, em princípio, subjugada às normas de direito sucessório.

Diante da complexidade e da riqueza do tema, não se pretende esgotar o assunto ou dar respostas definitivas neste trabalho, mas espera- se que este contribua para o fomento de uma área carente de pesquisa.

\footnotetext{
${ }^{32}$ Utilizamos neste trabalho a expressão "balcão" para nos referirmos ao local, em ambiente comercial, em que os vendedores mostram aos clientes as mercadorias ou produtos. (Segundo o dicionário Houaiss, disponível em <http://houaiss.uol.com.br/busca?palavra=balc\%E3o>, acesso em 08/01/12).

33 As consequências decorrentes da atribuição da natureza jurídica da reserva matemática, entretanto, não serão objeto de abordagem nesta dissertação.
} 


\section{ORGANIZAÇÃO DO TRABALHO}

Organizou-se a exposição em quatro partes: na primeira, foi traçado um painel da previdência, desenrolando breve panorama histórico até a atualidade, destacando suas principais características. Aqui se sublinhou o seu caráter contributivo e foi feita a diferenciação entre provisão técnica e reserva matemática. Foram apresentadas ainda as modalidades dos planos (BD, CD e CV) e seus principais tipos - PGBL, VGBL e FAPI.

O segundo capítulo foi dedicado ao bancassurance, com o objetivo de demonstrar o cenário atual do mercado segurador e de investimentos, no qual os limites entre os produtos financeiros e securitários ou de previdência privada são cada vez mais sutis, e quais implicações tal fenômeno pode trazer para o Direito.

O terceiro capítulo cuidou das características dos contratos de seguros. Partiu-se da análise geral da evolução do risco, passando por um breve histórico do instituto seguro e, particularmente, da sua história no Brasil. Foram diferenciados os seguros privados dos sociais, os seguros de danos dos de pessoas e, dentro desses últimos, os seguros com cobertura por morte, por sobrevivência e os mistos. Por fim, neste mesmo capítulo foram explicitados os elementos desse contrato, fundamentais para sua caracterização.

O quarto capítulo, reservado à finalização do trabalho, confrontou os elementos caracterizadores do contrato de seguro com os da previdência privada, procurando encontrar características que os aproximam e os afastam, com o objetivo de fornecer elementos para concluir, afinal, se a reserva matemática dos planos de previdência privada tem ou não natureza securitária. 


\section{DIREITO COMPARADO}

Como já defendia Tullio Ascarellii ${ }^{34}$ o Direito Comparado "permite ampliar nossa experiência jurídica no espaço", "auxilia-nos a compreender as relações entre as normas jurídicas e a subjacente realidade social" e é "indispensável para o progresso econômico dos diversos países, oferecendo a possibilidade de utilizar, cada qual, as alheias diferenças".

Considerando a mencionada míngua de obras que tratem da previdência privada no Brasil, e com o intuito de ampliar a reflexão sobre o assunto, recorremos à doutrina estrangeira, principalmente à portuguesa, espanhola, italiana e francesa, sempre que possível, tendo sido ainda de utilidade a literatura argentina, inglesa e americana.

O papel da doutrina europeia ocidental é de grande contribuição para o desenvolvimento do raciocínio lógico a respeito da operação securitária e dos planos previdenciários privados. Aqueles países possuem amplo leque de produtos securitários de "capitalização 35 " ou acumulação, guardando semelhanças com o modelo brasileiro, além de contarem com generoso material de pesquisa acerca dessa delimitação da natureza jurídica de cada um.

Ademais, o estudo jurídico do bancassurance na Europa Ocidental é bastante desenvolvido, quando comparado com o que temos no Brasil, o que possibilitou um olhar diferenciado sobre os produtos que pretendemos investigar.

\footnotetext{
${ }^{34}$ Problemas das sociedades anônimas e direito comparado. Campinas: Bookseller, 1999, p. 34.

${ }^{35}$ Nomenclatura utilizada em tais países para designar produtos "securitários" ou "previdenciários" em que o caráter mais evidente é o aspecto financeiro.
} 


\title{
CAPÍTULO I - PANORAMA DA PREVIDÊNCIA PRIVADA
}

\section{1- Evolução da previdência}

\begin{abstract}
Nossa sociedade recusa a fatalidade. Ela se caracteriza pela crescente exigência de segurança. Esta exigência gera a convicção de que qualquer risco deve ser coberto, que a reparação de qualquer dano deve ser rápida e integral e a sociedade deve prover, por isso, não somente uma indenização dos danos que ela própria gerou, como também aqueles que não conseguiu impedir ou que não soube prever a ocorrência. ${ }^{36}$
\end{abstract}

A solidariedade, mecanismo mais primitivo e intuitivo do indivíduo para proteção, evoluiu e encaminhou-se para a criação de organizações religiosas ou montes de piedade, reunindo pessoas expostas aos mesmos tipos de riscos. Isso porque se percebeu que, em conjunto, era mais fácil enfrentar os perigos do que individualmente. ${ }^{37}$

Na época da Idade Média, por exemplo, a ajuda originava-se da igreja ${ }^{38}$ ou, em alguns casos, da "bondade" de algum rei que se compadecia de determinada situação ${ }^{39}$. Essa solidariedade, contudo, não era institucionalizada.

Pelas constantes transformações ocorridas ao longo da história, o Estado despontou não só como instituição, mas também passou a ser visto como uma entidade que deveria se responsabilizar pelos riscos que advinham da vida em sociedade ${ }^{40}$.

${ }^{36}$ VARELLA, Marcelo Dias (Coord.). Responsabilidade e Socialização do Risco, p. 9. Disponível em: $<$ http:// www.estig.ipbeja.pt/ ac_direito/Varella2.pdf>. Acesso em 01/10/2013.

${ }^{37}$ Como ensina Pedro Alvim (op. cit, p. 2).

38 Eliane Romeiro Costa explica que a Igreja Católica foi importante instituição de ajuda aos pobres, assumindo e desenvolvendo por séculos o papel de minimização da indigência. "Não se trata de direito legal, mas de ação moral calcada no atendimento do tido como necessário, por meio de esmolas em dinheiro, doações de roupas, calçados, alimentos e bebida, auxílio aos velhos, órfãos, viúvas, doentes ou mesmo, entre outras medidas, pela concessão de sepultura aos mortos. A atividade do cristão, como espírito de sacrifício por amor ao próximo, consistia nas manifestações de caridade. Com o advento da Reforma na Europa, transfere-se para o setor laico o atendimento da "Assistência". Em outros termos, nota-se a transferência da atividade previdenciária privada para a assistência pública." (Previdência Complementar na Seguridade Social - o risco velhice e a idade para a aposentadoria. São Paulo: LTr, 2003, p. 37)

${ }^{39}$ Conforme a lição de Marcelo Dias Varella: "Também as autoridades medievais não ignoravam totalmente a compensação em dinheiro ligada a certos problemas. Quando um indivíduo sofria danos particularmente anormais, em razão de obras ou construções públicas ou em matéria de desapropriação, as autoridades revertiam-lhe uma compensação, mesmo quando não tinham cometido erro. Todavia, não se tratava de responsabilidade do rei (o dogma sendo: O rei não pode errar, mas de um procedimento gracioso considerado como magnanimidade do rei, mesmo quando se tornava mais sistemático)”. (Op. cit., p. 15)

${ }^{40}$ Sobre este tema, Marcelo Dias Varella relata que, em 1895, na cidade francesa de Tarbes, um operário do serviço público foi vítima de um acidente do trabalho, tendo sido atingido por um estilhaço de metal 
Essa característica foi acentuada com a Revolução Industrial, quando o campo deixou de ser o grande centro produtor de riquezas e houve forte atração de trabalhadores para os centros urbanos.

Nas economias rurais, predominantes até então, a "aposentadoria" muitas vezes consistia na própria continuidade da produção agrícola e no trabalho dos herdeiros ${ }^{41}$, de modo que não se demandava uma efetiva preocupação por parte do Estado com relação aos chamados "riscos sociais" 42 .

Todavia, com a Revolução, a vida familiar mudou. Os mais jovens foram se aventurar nas grandes cidades, modificando aquela ideia de "aposentadoria fundada no trabalho dos herdeiros". A família ampliada deu lugar a uma mais restrita, nuclear, composta pelos pais e filhos, fundamentalmente ${ }^{43}$.

projetado pelo choque que um martelo pilão. O governo francês, na altura, chamou o ocorrido de "acidente anônimo", e não assumiu qualquer responsabilidade pelo mesmo. Contudo, a jurisprudência administrativa (Parecer Cames - CE 21/6/1895) reconheceu a responsabilidade do Estado e o dever de indenizar a vítima. O mesmo autor cita outro precedente jurisprudencial da França, desta vez com relação a um operário de empresa privada, que faleceu em consequência da explosão de um cano de vapor em um rebocador, e a viúva intentou uma ação contra seu empregador. Neste caso, em oposição ao caso anterior, a jurisprudência afastou o dever de indenizar por parte do empregador. Entendeu-se que somente se podia aplicar uma solução semelhante à do outro caso se os empregadores e empregados entrassem em acordo, aceitando uma socialização das suas responsabilidades pelo risco profissional, o que posteriormente evoluiu para a criação do sistema de seguridade social. (op. cit, p. 23)

${ }^{41}$ Nas palavras de Carlos José María Facal (El seguro de vida en la Argentina, Buenos Aires: Lexis Nexis, 2007, p. 2): A Bíblia, entre outros, chama de felizardo a quem tem uma larga descendência, dedica-se a cuidar de órfãos e das viúvas e promete filhos ao homem justo, os quais assegura que virão numerosos como as areias do deserto ou as estrelas do céu. Por isso, não podia haver pior desgraça do que a esterilidade, já que quem não contava com uma família ficava condenado ao abandono na velhice e na doença. Uma família era a mais completa proteção que um homem podia adquirir na sua vida: uma família que dele cuidaria e o alimentaria quando suas forças lhe faltassem. Por isso, a família era também a recompensa do justo por observar os desejos e preceitos de Deus. (Tradução livre) "La Biblia, entre otros, llama dichoso a quien tiene una larga descendencia, insta a cuidar de los órfanos y de las viudas y promete hijos al hombre justo, los que asegura que vendrán numerosos como las arenas del desierto o las estrellas del firmamento. Por entonces no podía haber peor desgracia que la esterilidad, ya que quien no contaba con la familia quedaba condenado al abandono en la vejez y la enfermedad. Una familia era la más completa protección que un hombre podía hallar en su vida: una familia que lo cuidara y alimentara cuando sus fuerzas lo abandonaran. Por eso la familia era también la recompensa del justo por observar los deseos y preceptos de Dios."

${ }^{42}$ Conforme definição de Manuel Soares Póvoas: "riscos sociais são os perigos a que estão submetidos os homens em sociedade, e cuja materialização se reflete sempre, negativamente, e em seu bem-estar e no de sua família, criando problemas sociais." (Previdência privada - Filosofia. Op. cit., p. 64)

43 "A industrialização acarretou o fim dessa concepção familiar. A indústria retirou da família a função de fator de produção e, conseqüentemente, a autoridade do chefe sobre os demais membros. O homem passa a trabalhar nas fábricas. E a mulher, ingressa no mercado de trabalho, com o fim de ajudar no sustento da família, causando profundas transformações na hierarquia familiar, pois começam a surgir os ideais da igualdade de direitos, advindos da Declaração Universal dos Direitos do Homem. Outro ponto significativo é que as famílias, antes numerosas, se restringem devido ao controle de natalidade e também pelas péssimas condições de vida." (SANTOS, Jonabio Barbosa dos; SANTOS, Morgana Sales da Costa. Família 
Com essa transição para a economia industrial, multiplicaram-se as fontes de risco, pois a progressiva sofisticação técnica e sua maior dimensão conduziram à criação e concentração de novos perigos ${ }^{44}$.

Nos centros industriais então recém-criados, os idosos, as vítimas de acidentes, de doenças e de outros fatores que afetavam sua capacidade de trabalho ficavam relegados à própria sorte por não haver, na altura, instituição que lhes provesse alguma ajuda financeira.

Paralelamente a essa mudança familiar e econômica, também do ponto de vista político houve modificações significativas na mentalidade do homem. Se, no princípio, ele era menos exigente - contentando-se com medidas pontuais de solidariedade praticadas pela igreja ou por um rei que, por graça, compensava alguns danos causados -, com a Revolução Francesa rompeu-se a ideia de socorro por pura caridade, incentivando-se a poupança individual e a busca por outros meios de reparação de danos ${ }^{45}$.

A ação estatal de maneira mais institucionalizada de que se tem notícia remonta ao final do século XIX, em 1883, na Alemanha. O Chanceler Otto Von Bismarck criou um sistema de seguro social ${ }^{46}$, cuja gestão era feita pelo Estado ${ }^{47}$, conferindo aos trabalhadores

monoparental brasileira in Rev. Jur., Brasília, v. 10, n. 92, p.5, out./2008 a jan./2009, disponível em <http://www.presidencia.gov.br/revistajuridica>, acesso em 22/12/2013.

${ }^{44}$ Neste sentido, Marcelo Dias Varella: “O progresso técnico é uma fonte de riscos. As causas e os efeitos de certos riscos são mais complexos e mais difíceis de individualizar. A mundialização e a crescente urbanização levam a mudanças de escala. A fronteira entre risco tecnológico e risco natural torna-se mais vaga". (op. cit, p. 9) Para Manuel Soares Póvoas, "O Estado Assistencial é um produto da época do aço, da época do uso industrial da eletricidade e da especialização do trabalho" (Previdência Privada - filosofia, op. cit., p. 44)

45 "A Revolução Francesa marca um fim e uma virada: destrói as bases da solidariedade arcaica, corporativista e, principalmente, familiar, bem como visa instituir um outro tipo de solidariedade que se apóia, em parte, sobre os desenvolvimentos da técnica atuarial; ela começa a estabelecer ligações estreitas entre um tipo de solidariedade nacional frente aos danos, baseada na igualdade, e um novo conceito aparece, ainda sem nitidez de responsabilidade das pessoas públicas, de dívida/credor, ou seja, a indenização de certos danos - que podem ocorrer durante atividades de interesse geral - não é mais considerada um gracioso favor por parte do soberano junto a seus súditos, mas resulta de uma dívida do Estado perante os cidadãos." (VARELLA, Marcelo Dias. Op. cit., pp. 16-17)

${ }^{46}$ Conforme lecionam Marcus Orione Gonçalves Correia e Érica Paula Barcha (Curso de Direito da Seguridade Social. São Paulo: Saraiva, 2008, p. 5).

${ }^{47}$ Vide VIANNA, Maria Lucia Teixeira Werneck, Em torno do conceito de política social: notas introdutórias, disponível em <http://www.enap.gov.br/downloads/ec43ea4fMariaLucia1.pdf>, acesso em 22/12/13. 
direito ao recebimento de benefícios, mediante o pagamento de contribuição de empregados e empregadores, incidente sobre a folha de salários.

Esse modelo ganhou maior destaque no século $\mathrm{XX}$, espalhando-se para outros países (sobretudo do ocidente) a partir da Primeira Guerra Mundial, mas com mais força após a Segunda.

Em 1942, foi criado na Inglaterra o Plano Beveridge, que propôs a instituição do Welfare State ("Estado do Bem-Estar Social") ${ }^{48}$. O Estado passou a adotar uma postura de intervenção direta na atividade econômica, de gestão minuciosa em determinados setores da vida social, tal como a própria previdência.

Os direitos sociais passaram a ser vistos como de caráter universal, no sentido de prover um mínimo social a todos em condições de necessidade ${ }^{49}$.

\subsection{Previdência social no Brasil}

O Estado brasileiro oferece proteção à população por meio do seu sistema de seguridade social ${ }^{50}$, que compreende saúde, assistência e previdência social, nos termos do

${ }^{48}$ Conforme Marcus Orione Gonçalves Correia e Érica Paula Barcha (op. cit., p. 9), “a imprensa popular teria, inclusive, cunhado a seguinte frase para definir o Plano: "from the cradle to the grave" (do berço ao túmulo) - em alusão à cobertura de todas as necessidades humanas desde o nascimento até a morte."

${ }^{49}$ Neste sentido, vide Marcus Orione Gonçalves Correia e Érica Paula Barcha (op. cit.).

${ }^{50}$ Vários autores buscaram conceituar a Seguridade Social. Para Eliane Romeiro Costa, "ela se apresenta como o conjunto de idéias adotadas pelo Estado objetivando o bem-estar do indivíduo. $\mathrm{O}$ valor fundamental para o ideal de Seguridade é a proteção do todo, do conjunto de cidadãos, cujas metas priorizam as situações das necessidades individuais. A otimização das condições econômicas do conjunto social não elimina a situação de risco individual, cabendo essa tarefa à política de seguridade social estatal. (...) Há muitos conceitos de seguridade social. As concepções demonstram a dificuldade de precisar o sentido. A seguridade como segurança que ameniza as situações futuras é processo que concretiza a realização do ser humano. $\mathrm{O}$ direito social à seguridade intenta a igualdade, a generalidade da cobertura e a redistribuição dos riscos. A seguridade desempenha função de seguradora." (op. cit, p. 36) Para Póvoas, "é um processo sócio-econômico ao nível de cada nação utilizando a solidariedade entre entidades e pessoas que representam as suas forças produtivas e beneficiando de uma estrutura operacional definida, orientada e controlada pelo estado, objetiva proporcionar a cada pessoa os meios indispensáveis para, nas eventualidades negativas da sua vida, em termos de perda de sua capacidade de ganho por razões aleatórias como o desemprego, a doença, o acidente, ou por razões inerentes à própria condição humana como o casamento, a maternidade, a infância, a velhice e a morte, poder suportar as conseqüências, nomeadamente ter assegurado o sustento da família." (Previdência privada - filosofia. Op. cit, p. 61) Celso Barroso Leite apresenta a seguridade social como: “o conjunto das medidas com as quais o Estado, agente da sociedade, procura atender à necessidade que o ser humano tem de segurança na adversidade, de tranquilidade quanto ao dia de amanhã." (Conceito de Seguridade Social in 
art. 194 da Constituição Federal: “A seguridade social compreende um conjunto integrado de ações de iniciativa dos Poderes Públicos e da sociedade, destinadas a assegurar os direitos relativos à saúde, à previdência e à assistência social.” (n.g.)

A previdência, por sua vez, apoia-se em três pilares: Regime Geral de Previdência Social (RGPS), Regimes Próprios de Previdência Social (RPPS) e previdência privada.

A partir dos anos 70 e 80, verificou-se progressiva diminuição da atuação direta do Estado brasileiro ${ }^{51}$ sobre alguns setores, com certo esvaziamento do Poder Público e redução do seu papel de promotor do bem-estar social, inclusive sobre a seguridade, abrindo espaço para intensificação da ação da iniciativa privada ${ }^{52}$.

Deste modo, reconhece-se na previdência privada o desempenho de atividade relacionada com a seguridade social e, mais especificamente, com a previdência social. É oferecida e operada por particulares, em regime privado de exploração de atividade econômica, mas submetida à ação normativa e fiscalizadora do Estado.

Neste sentido é a doutrina de Daniel Pulino ${ }^{53}$ :

Também na área de previdência social pode-se vislumbrar, a exemplo do que vimos ocorrer na saúde - e na assistência social (...), a atuação de sujeitos particulares tanto em estreita colaboração com o Poder Público desempenhando atividades, senão em nome do Estado, pelo menos investidos em função pública e, nesta medida, agindo em lugar deste vale dizer, para conceder prestação que a ele, Estado, competiria entregar -, quanto em exploração da atividade econômica em regime de direito privado - ainda que submetido, é certo, a especial, a mais estreita disciplina de intervenção estatal -, com fins lucrativos ou não.

Curso de Direito Previdenciário. Homenagem a Moacyr Velloso Cardoso de Oliveira - coordenação de Wagner Balera, $5^{\text {a }}$ ed. São Paulo: LTr, 2002, pp. 17 e 18.)

${ }^{51}$ E isso não ocorreu somente no Estado brasileiro. José Corrêa Villela denomina as mudanças ocorridas nos anos 70 de "projeto neoliberal", o qual consistiria na "contrapropaganda ao Estado do bem-estar social", tendo início com os governos de Margareth Thatcher, na Inglaterra (principalmente), e Ronald Reagan, nos Estados Unidos. Alguns pontos da "privatização" da previdência e da Lei Complementar $n^{\circ} 108 / 01$ in Previdência Privada. Doutrina e Comentários à Lei Complementar $n^{o}$ 109/01. Marcus Orione Gonçalves Correia (coord.); José Corrêa Villela (org.). São Paulo: LTr, 2004, p. 27.

${ }^{52}$ V.g. Emenda Constitucional $n^{\circ} 41 / 03$, que estimulou a previdência complementar dos servidores públicos e estabeleceu teto para o valor dos benefícios do regime geral de previdência social.

${ }^{53}$ PULINO, Daniel. Op. cit., p. 71. 
Logo, a previdência privada cumpre importante papel social, operando e provendo benefícios de natureza semelhante aos do RGPS e RPPS, atuando em estreita colaboração com o Poder Público.

\subsection{Surgimento da previdência privada no Brasil}

Curiosamente, embora sob a ótica de seu desenvolvimento e regulamentação a previdência privada seja uma matéria relativamente juvenil em nosso país, do ponto de vista fático ela é mais antiga que a própria previdência social.

A primeira entidade de previdência privada brasileira, o MONGERAL Montepio Geral da Economia dos Servidores do Estado - surgiu em $1828^{54}$, ao passo que a primeira instituição de previdência social de caráter abrangente do país, o Instituto Nacional da Previdência Social (INPS) passou a existir apenas em $1967^{55}$, quase cento e quarenta anos depois ${ }^{56}$.

Durante décadas, a previdência privada no Brasil funcionou de maneira bastante rudimentar e precária, sem vigilância efetiva por parte do Estado, sem regulamentação específica nem critérios que garantissem aos participantes uma forma de proteção consistente. Os planos de algumas entidades eram insustentáveis financeiramente, ou não passavam de "promessas enganosas"

Não havia controle estatal sobre as regras dos planos oferecidos, os quais muitas vezes não previam critérios de correção e atualização monetária, de modo que a inflação corroía os valores prometidos. Os participantes tinham pouca informação sobre os produtos

\footnotetext{
${ }^{54}$ Fonte: Susep. <http://www.susep.gov.br/menu/a-susep/historia-do-seguro>, acesso em 01/11/2013.

${ }^{55}$ Criado por meio do Decreto-Lei $n^{\circ} 72 / 66$, reuniu os seis Institutos de Aposentadorias e Pensões no Instituto Nacional de Previdência Social - INPS.

56 Embora desde 1888 já se observassem iniciativas pontuais de proteção de certas categorias de trabalhadores. V.g. empregados dos correios (Decreto $\mathrm{n}^{\circ}$ 9.912-A/ 1888); Oficinas de Imprensa Nacional (Decreto $\mathrm{n}^{\circ}$ 10.269/1889); empregados do Ministério da Fazenda (942-A/1890), dentre outros. Fonte: Histórico da previdência social. Disponível em <http://www.previdencia.gov.br/a-previdencia/historico/>. Acesso em 15/02/13.

${ }^{57}$ Fazendo uso da expressão de Luís Eduardo Afonso (Previdência social e fundos de pensão. Rio de Janeiro: FUNENSEG, 1996, p. 41).
} 
que contratavam (às vezes nem recebiam os regulamentos e demais instrumentos contratuais). Com isso, a imagem da previdência privada no país acabou ficando maculada ${ }^{58}$.

Em 1966, foi publicado o Decreto-Lei $\mathrm{n}^{\circ} 73$, subordinando todas as atividades de seguros privados (incluindo a previdência privada aberta) ao controle do Estado, por meio da então recém-criada Superintendência Nacional de Seguros Privados (SUSEP) e do Conselho Nacional de Seguros Privados (CNSP).

Em 1977, pela primeira vez na história brasileira, foi publicada uma lei que tratou especificamente da operação de previdenciária privada: a Lei ${ }^{\circ} 6.435$. Dentre as principais inovações trazidas para a época destacou-se a exigência de autorização do Poder Público para a operação de planos previdenciários, o estabelecimento de elementos mínimos para a elaboração dos regulamentos dos planos, com a expressa determinação de sistema de revisão e atualização monetária de valores de contribuições e benefícios (art. 21, IV e art. 22).

O novo quadro legal conferiu maior segurança e credibilidade às operações realizadas, mas ainda assim a previdência privada encontrava obstáculos para seu desenvolvimento no país, devido à alta inflação ${ }^{59}$ e à falta de estabilidade que assolou a economia nacional durante décadas ${ }^{60}$.

\footnotetext{
${ }^{58}$ A respeito da experiência passada, é o entendimento de Marina Célia Requejo de Sá: "No passado vivemos uma experiência traumática em relação aos montepios, que venderam planos sem dispor de reservas necessárias para o pagamento de eventuais sinistros, por esse motivo, alguns faliram e outros não honraram seus compromissos. Esse acontecimento negativo em relação à garantia do sistema ocorreu por falta de fiscalização. De lá para cá, foram introduzidas mudanças substanciais no controle dessas entidades, caracterizando-se, nitidamente, dois períodos distintos." (Entidades abertas de previdência privada, avaliação atuarial, margem de solvência e provisões técnicas: um setor em pleno desenvolvimento. In Cadernos de Seguro. Rio de Janeiro: FUNENSEG, a. XXIV, n 123, mar. 2004, p. 42)

59 "No Brasil, desde o final da década de 70 até meados dos anos 90, conviveu-se com elevadas taxas inflacionárias. Ao longo desse período, o País foi submetido a vários planos econômicos, ortodoxos e heterodoxos, mas nenhum teve sucesso efetivo no combate à inflação e na retomada do crescimentos econômico." Estabilização econômica no Brasil: reflexões sobre o Plano Real in Estabilização e crescimento: desafios do Plano Real. (FONTES, Rosa; ARBEX, Marcelo A.; SILVA JR, Geraldo E.) Disponível em < http://revistas.fee.tche.br/index.php/indicadores/article/viewFile/1570/1938>, acesso em $12 / 01 / 12$.

${ }^{60}$ Como explicam Raymundo Magliano Filho e Sergio Luiz de Cerqueira Silva: [sobre as décadas de 70 e 80] "Do lado dos fundos de pensão, a regulamentação começava a introduzir um arcabouço moderno de prevenção de riscos e de medidas de cautela na administração de recursos de terceiros. Porém, a economia brasileira não apresentava ainda características que levassem à disseminação da ideia de poupança individual e construção de um patrimônio pessoal e familiar para financiar a previdência". Fundos de pensão e um novo
} 


\subsection{Desenvolvimento da previdência privada após o Plano Real}

Foi somente na década de 90, com a implantação do Plano Real, que se atingiu a almejada estabilidade econômica e o controle da inflação no Brasil, permitindo o planejamento financeiro de longo prazo.

Nesse contexto, em 1998, foi publicada a Emenda Constitucional $\mathrm{n}^{\circ} 20$, que trouxe estampado no art. 202 o conceito de previdência privada:

O regime de previdência privada, de caráter complementar e organizado de forma autônoma em relação ao regime geral de previdência social, será facultativo, baseado na constituição de reservas que garantam o benefício contratado e regulado por lei complementar.

Como a emenda instituiu reserva legal à sua regulamentação, sobreveio a necessidade de uma nova lei. Assim, em 29 de maio de 2001, foi publicada a Lei Complementar $\mathrm{n}^{\circ} 109$, revogando a lei $\mathrm{n}^{\circ} 6.435 / 77$.

A legislação contemporânea representou significativo avanço para o setor, conferindo maior transparência ${ }^{61}$, flexibilidade ${ }^{62}$ e segurança ${ }^{63}$ ao sistema privado.

modelo de desenvolvimento in Papel dos fundos de pensão na formação da economia brasileira Capitalismo social, (coord. GÓES, Wagner). São Paulo: ABRAPP / ICSS / SINDAP, 2007, p. 15.

${ }^{61}$ Conforme Leonardo André Paixão, "pelo princípio da transparência, sendo o destinatário final dos recursos capitalizados, o participante tem direito de conhecer todos os aspectos que nvolvem a administração do plano de previdência a que aderiu (investimentos, despesas administrativas)." A previdência complementar fechada: uma visão geral. Disponível em: <http://www.previdencia.gov.br/arquivos/office/3_081014111321-983.pdf >. Acesso em: 12/11/2013.

62 "O princípio constitucional da flexibilidade restou efetivado pela Lei Complementar no 109/01 através dos institutos do resgate, portabilidade, vesting e autopatrocínio. Esses quatro institutos, obrigatórios a todos os planos, sejam eles posteriores ou anteriores à Lei Complementar nº 109/01, flexibilizaram a relação jurídica, possibilitando ao participante mobilidade no âmbito do sistema previdenciário privado." (WEINTRAUB, Arthur Bragança de Vasconcellos; VIANA, Bárbara Berbert Baer; LEVY, Dan Rodrigues; LEMOS, Thales) Peculiaridades dos programas de previdência privada e institutos obrigatórios. Disponível em: < http://revbprev.unifesp.br/index.php/edic/20-dois/31-peculiaridades>. Acesso em: 05/12/2012.

${ }^{63}$ A segurança diz respeito, sobretudo, aos aspectos econômico-financeiros e atuariais, como reza o inciso III do art. $3^{\circ}$ da LC 109/01: "A ação do Estado será exercida com o objetivo de: (...) determinar padrões mínimos de segurança econômico-financeira e atuarial, com fins específicos de preservar a liquidez, a solvência e o equilíbrio dos planos de benefícios, isoladamente, e de cada entidade de previdência complementar, no conjunto de suas atividades (...)." Neste sentido é a lição de Voltaire Marensi: "Uma das características existentes na estrutura desta Lei [LC 109/01] se refere à intenção do legislador em dar maior segurança e 
Incorporou em seu texto algumas práticas de mercado ainda não regulamentadas, tais como a portabilidade ${ }^{64}$, o instituto do autopatrocínio ${ }^{65}$ e do benefício proporcional diferido ${ }^{66}$. Inovou também ao permitir a criação de planos instituídos ${ }^{67}$ de entidades fechadas, nos quais o vínculo entre entidade e participantes dá-se pelo caráter profissional, classista ou setorial.

Como as últimas décadas propiciaram um ambiente econômico e regulatório favorável à previdência privada, as reservas acumuladas nos planos das entidades abertas cresceram exponencialmente, como se pode constatar pela análise do gráfico a seguir ${ }^{68}$, havendo perspectiva de incremento nos números para os próximos anos ${ }^{69}$ :

\section{Gráfico 1 - Evolução da carteira de investimentos das entidades abertas}

confiabilidade ao regime de previdência privada, mote com maior proteção aos participantes destes planos." A nova lei da previdência complementar comentada. Porto Alegre: Síntese, 2001, p. 11.

${ }^{64}$ Nos termos do art. 14, II (aplicável às entidades fechadas) e art. 27 (aplicável às entidades fechadas) da LC 109/01. A portabilidade é o instituto que "atribui ao participante a faculdade de transferir os valores existentes e seu nome em um plano de uma entidade de previdência privada para outro plano da mesma ou de outra pessoa jurídica. (...) confere ao titular do direito acumulado a possibilidade de transferi-lo ara uma entidade aberta ou fechada, somente exigindo que se trate de uma instituição de previdência complementar." (CORREIA, Marcus Orione Gonçalves (coord.); VILlELA, José Corrêa (org.). Previdência Privada. Doutrina e Comentários à Lei Complementar no 109/01. São Paulo: LTr, 2004, p. 264).

${ }^{65}$ Aplicável às entidades fechadas, conforme art. 14, IV da LC 109/01. É definido no art. 27 da Resolução CGPC n ${ }^{\circ}$ 06/03: "Entende-se por autopatrocínio a faculdade de o participante manter o valor de sua contribuição e a do patrocinador, no caso de perda parcial ou total da remuneração recebida, para assegurar a percepção dos benefícios nos níveis correspondentes àquela remuneração ou em outros definidos em normas regulamentares."

${ }^{66}$ Aplicável às entidades fechadas, conforme art. 14, I da LC 109/01. É definido no art. $2^{\circ}$ da Resolução CGPC n ${ }^{\circ}$ 06/03 como: "Entende-se por benefício proporcional diferido o instituto que faculta ao participante, em razão da cessação do vínculo empregatício com o patrocinador ou associativo com o instituidor antes da aquisição do direito ao benefício pleno, optar por receber, em tempo futuro, o benefício decorrente dessa opção."

${ }^{67}$ Art. 31, II da LC 109/01.

${ }^{68}$ Fonte: Dados estatísticos - Planos de Caráter Previdenciário - Junho 2013 - FENAPREVI. Disponível em: 〈http://www.cnseg.org.br/fenaprevi/estatisticas/estatisticas.html〉. Acesso em: 02/09/13.

69 Sobre este tema, ver OLIVEIRA, Francisco E. Barreto de; PASINATO, Maria Tereza de Marsillac; PEYNEAU, Fernanda Paes Leme. Evolução recente do sistema de previdência complementar no Brasil e mercado potencial. Disponível em: <http://www.abep.nepo.unicamp.br/docs/anais/pdf/2000/Todos/evolu\%C3\%A7\%C3\%A3o\%20Recente\%20d o\%20Sistema\%20de\%20Previd\%C3\%AAncia\%20Complementar....pdf:, >. Acesso em: 05/01/13. 


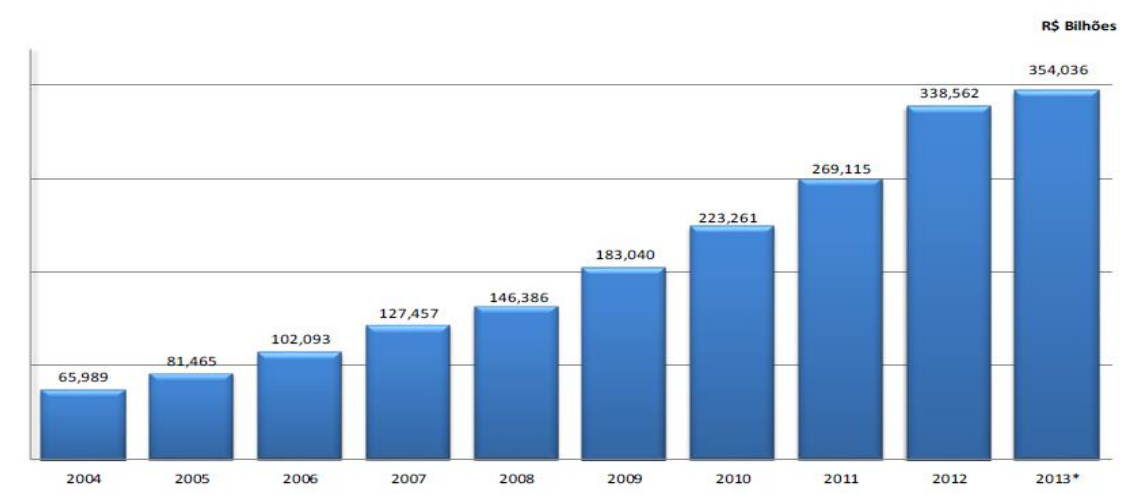

\subsection{Principais características da previdência privada}

Do conceito de previdência privada trazido no art. 202 da CF podem ser extraídas suas principais características:

O regime de previdência privada, de caráter complementar e organizado de forma autônoma em relação ao regime geral de previdência social, será facultativo, baseado na constituição de reservas que garantam o benefício contratado, e regulado por lei complementar. (n.g.)

\subsubsection{Caráter privado}

Primeiramente, é um regime de natureza privada, pois é operado por entidades de direito privado (fechadas ou abertas), diferentemente do que ocorre com a previdência social (gerida por entidades de direito público ${ }^{70}$ ).

Entretanto, como adverte Enéas Virgílio Saldanha Bayão ${ }^{71}$ :

\footnotetext{
${ }^{70}$ V.g. INSS.

${ }^{71}$ BAYÃO, Enéas Virgílio Saldanha. Responsabilidade civil, administrativa e criminal dos dirigentes de EFPC in Gestão de Fundos de Pensão: Aspectos Jurídicos. GÓES, Wagner (coord.). São Paulo: Associação Brasileira das Entidades Fechadas de Previdência Complementar - ABRAPP, 2006, p. 157.
} 
Quando se fala em "natureza privada" como inerente ao sistema de previdência complementar brasileiro, não se pode olvidar que, em realidade, a autonomia da vontade das entidades EFPC é bastante mitigada, haja vista o intensivo e necessário controle estatal incidente sobre tais entidades e seus planos, seja no momento de sua constituição, na criação dos planos de benefícios ou na aplicação de seus recursos.

O mesmo autor ${ }^{72}$ continua:

A vontade das partes não é absoluta, ao contrário, observa-se um rígido controle estatal sobre seu funcionamento, porque tais entidades exercem uma complementação ao dever do Estado de prover uma previdência social digna e justa, direito social e fundamental inscrito no caput do art. $6^{\circ}$ da Constituição Federal. (...) Está-se, aqui, diante do princípio da supremacia da ordem pública, que, de resto, ao lado dos princípios da autonomia da vontade e do da obrigatoriedade, integram os fundamentos de qualquer contrato.

Ou seja, verifica-se que, não obstante o caráter privado do regime, a previdência privada é fortemente impregnada pelo controle estatal, por meio dos órgãos regulador (CNSP) e fiscalizador (Susep), que estabelecem diretrizes para o funcionamento das entidades $^{73}$, aprovam sua criação ${ }^{74}$, controlam sua operação ${ }^{75}$, fiscalizam e autuam as entidades em caso de desobediência ${ }^{76}$.

\subsubsection{Complementaridade}

A previdência privada é um regime complementar ao RGPS ou RPPS, pois permite ao participante, por meio de um acréscimo em relação ao nível do benefício da previdência social, garantir, no momento de sua aposentadoria, padrão de vida compatível com o experimentado quando estava em atividade laborativa.

Conforme a doutrina de Wagner Balera ${ }^{77}$ :

\footnotetext{
${ }^{72}$ Idem, ibidem.

${ }^{73}$ Nos termos do art. $3^{\circ}$ da LC 109/01.

${ }^{74}$ Conforme o art. 38 da LC 109/01.

${ }^{75}$ V.g. por meio da exigência do envio periódico de informações, por meio do Formulário de Informações Periódicas - FIP/SUSEP, disciplinado por meio da Circular Susep nº 36408.

${ }^{76}$ Nos termos da Resolução CNSP n ${ }^{\circ} 243 / 11$.

${ }^{77}$ BALERA, Wagner. Sistema de seguridade social. $4^{\text {a }}$ ed. São Paulo: LTr, 2006, p. 15.
} 
Ao regime complementar, por seu turno, compete proporcionar planos de proteção que atendam à demanda daquela parcela da comunidade cujas rendas se situem acima dos limites de proteção estabelecidos pelo regime geral e pelo regime próprio.

Logo, a ideia de complementaridade refere-se aos indivíduos que auferem remuneração superior ao teto da previdência social, já que, a rigor, quem recebe valores inferiores não necessitaria de complementação de benefício, pois, ao se aposentar, manteria, a princípio, o mesmo padrão de remuneração do momento de atividade laborativa $^{78}$.

Não obstante, pode ainda ser utilizada como sistema suplementar, ou seja, proporcionando aos participantes um valor superior ao recebido na fase de atividade.

\section{Como ensina Eliane Romeiro Costa ${ }^{79}$ :}

O significado "complementar" compreende um modelo paralelo ao básico, destinado a "adicionar" o bem - estar dos trabalhadores. O bemestar é serviço previdenciário opcional, custeado com contribuições adicionais conforme redação anterior à Emenda Constitucional $n^{\circ} 20$. O bem-estar suplementar privado equivale ao campo não preenchido pelas políticas públicas de seguridade e de previdência social básicas. Trata-se da majoração dos benefícios de caráter previdenciário fundados no contrato, como poupança de capitalização ou como conta de capitalização previdenciária.

Em outras palavras, embora a previdência privada seja um regime complementar, por força do próprio texto constitucional, ela pode também desempenhar papel de suplementação dos benefícios.

\footnotetext{
${ }^{78}$ Entretanto, "dados indicam que o poder de compra da aposentadoria concedida pelo INSS tem apresentado uma expressiva perda, notadamente para aqueles aposentados que recebem mais de um salário mínimo (SM). No período de 1997 a 2012, os reajustes das aposentadorias com valor igual a um SM totalizaram 455\%, enquanto que, para os que receberam aposentadorias com valores maiores do que o salário mínimo, esse reajuste foi de 169\%. Considerando a inflação acumulada (IGP-M) no período (01/01/1997 a 31/12/2011), os reajustes reais dessas aposentadorias foram de $58,69 \%$ e perda de $22,95 \%$, respectivamente. Portanto, as pessoas que recebem valores de aposentadoria acima de um salário mínimo constituem o público interessado no sistema de previdência privada, face à acentuada perda do poder aquisitivo dos seus proventos ao longo do tempo." (Namilton Nei Alves Coelho; Marcos Antônio de Camargos) Fundos de pensão no Brasil: uma análise dos fatores determinantes para sua expansão na perspectiva dos seus gestores. Organ. Soc. Salvador, v. 19, $\mathrm{n}^{\circ}$ 61, Junho de 2012. Disponível em: <http://www.scielo.br/scielo.php?script=sci_arttext\&pid=S1984-92302012000200006\&lng=en\&nrm=iso >. Acesso em: 27/09/13.

${ }^{79}$ Op. cit, p. 71.
} 
Eventualmente, pode ainda ser o único regime de previdência, no caso de indivíduos não vinculados a qualquer regime de previdência social.

Ademais, a previdência privada pode funcionar como instrumento de acumulação de recursos, de maneira similar a uma "poupança", não necessariamente vinculada à aposentadoria, objetivando, por exemplo, o financiamento da educação dos filhos, de um negócio, da aquisição de um imóvel, dentre outros.

\subsubsection{Autonomia}

A previdência privada é um regime autônomo, pois atua paralelamente à previdência social sem, contudo, substituí-la. A rigor, a concessão de seus benefícios independe da elegibilidade à aposentadoria conforme as regras do RGPS e do RPPS, estando adstrita somente aos critérios convencionados entre as partes.

Assim leciona Manuel Soares Póvoas ${ }^{80}$ :

A previdência privada é uma instituição paralela à previdência social, perseguindo os mesmos fins, mas diferindo em que a previdência oficial é de caráter público, e a previdência supletiva é de caráter privado; a primeira é compulsória e a segunda voluntária.

Conquanto também se destine a dotar os participantes de segurança e tranquilidade, assegurando-os contra riscos sociais, e mesmo sendo "uma extensão instrumental da previdência social, dentro da instituição da 'Seguridade Social"81, ela não se confunde com o RGPS e o RPPS.

\subsubsection{Facultatividade}

${ }^{80}$ PÓVOAS, Manuel Soares. Previdência Privada - planos empresariais, v. I. Rio de Janeiro: Fundação Escola Nacional de Seguros, 1991, p. 191.

${ }^{81}$ Idem, p. 192. 
A previdência privada é um regime facultativo, de origem contratual, em oposição à previdência social ${ }^{82}$ que, por força de lei, é obrigatória.

${ }^{82}$ A Lei ${ }^{\circ}$ 8.212/91 define no art. 12 quem são os segurados obrigatórios da previdência social: São segurados obrigatórios da Previdência Social as seguintes pessoas físicas: I - como empregado: a) aquele que presta serviço de natureza urbana ou rural à empresa, em caráter não eventual, sob sua subordinação e mediante remuneração, inclusive como diretor empregado; b) aquele que, contratado por empresa de trabalho temporário, definida em legislação específica, presta serviço para atender a necessidade transitória de substituição de pessoal regular e permanente ou a acréscimo extraordinário de serviços de outras empresas; c) o brasileiro ou estrangeiro domiciliado e contratado no Brasil para trabalhar como empregado em sucursal ou agência de empresa nacional no exterior; d) aquele que presta serviço no Brasil a missão diplomática ou a repartição consular de carreira estrangeira e a órgãos a ela subordinados, ou a membros dessas missões e repartições, excluídos o não-brasileiro sem residência permanente no Brasil e o brasileiro amparado pela legislação previdenciária do país da respectiva missão diplomática ou repartição consular; e) o brasileiro civil que trabalha para a União, no exterior, em organismos oficiais brasileiros ou internacionais dos quais o Brasil seja membro efetivo, ainda que lá domiciliado e contratado, salvo se segurado na forma da legislação vigente do país do domicílio; f) o brasileiro ou estrangeiro domiciliado e contratado no Brasil para trabalhar como empregado em empresa domiciliada no exterior, cuja maioria do capital votante pertença a empresa brasileira de capital nacional; g) o servidor público ocupante de cargo em comissão, sem vínculo efetivo com a União, Autarquias, inclusive em regime especial, e Fundações Públicas Federais; h) o exercente de mandato eletivo federal, estadual ou municipal, desde que não vinculado a regime próprio de previdência social; i) o empregado de organismo oficial internacional ou estrangeiro em funcionamento no Brasil, salvo quando coberto por regime próprio de previdência social; j) o exercente de mandato eletivo federal, estadual ou municipal, desde que não vinculado a regime próprio de previdência social; II - como empregado doméstico: aquele que presta serviço de natureza contínua a pessoa ou família, no âmbito residencial desta, em atividades sem fins lucrativos; III - como empresário: o titular de firma individual urbana ou rural, o diretor não empregado, o membro de conselho de administração de sociedade anônima, o sócio solidário, o sócio de indústria e o sócio cotista que participe da gestão ou receba remuneração decorrente de seu trabalho em empresa urbana ou rural; IV - como trabalhador autônomo: a) quem presta serviço de natureza urbana ou rural, em caráter eventual, a uma ou mais empresas, sem relação de emprego; b) a pessoa física que exerce, por conta própria, atividade econômica de natureza urbana, com fins lucrativos ou não; V - como equiparado a trabalhador autônomo, além dos casos previstos em legislação específica: a) a pessoa física, proprietária ou não, que explora atividade agropecuária ou pesqueira, em caráter permanente ou temporário, diretamente ou por intermédio de prepostos e com auxílio de empregados, utilizados a qualquer título, ainda que de forma não contínua; b) a pessoa física, proprietária ou não, que explora atividade de extração mineral garimpo, em caráter permanente ou temporário, diretamente ou por intermédio de prepostos e com auxílio de empregados, utilizados a qualquer título, ainda que de forma não contínua; c) o ministro de confissão religiosa e o membro de instituto de vida consagrada e de congregação ou de ordem religiosa, este quando por ela mantido, salvo se filiado obrigatoriamente à Previdência Social em razão de outra atividade, ou a outro sistema previdenciário, militar ou civil, ainda que na condição de inativo; d) o empregado de organismo oficial internacional ou estrangeiro em funcionamento no Brasil, salvo quando coberto por sistema próprio de previdência social; e) o brasileiro civil que trabalha no exterior para organismo oficial internacional do qual o Brasil é membro efetivo, ainda que lá domiciliado e contratado, salvo quando coberto por sistema de previdência social do país do domicílio; $\mathrm{V}$ - como contribuinte individual: a) a pessoa física, proprietária ou não, que explora atividade agropecuária ou pesqueira, em caráter permanente ou temporário, diretamente ou por intermédio de prepostos e com auxílio de empregados, utilizados a qualquer título, ainda que de forma não contínua; a) a pessoa física, proprietária ou não, que explora atividade agropecuária, a qualquer título, em caráter permanente ou temporário, em área superior a 4 (quatro) módulos fiscais; ou, quando em área igual ou inferior a 4 (quatro) módulos fiscais ou atividade pesqueira, com auxílio de empregados ou por intermédio de prepostos; ou ainda nas hipóteses dos $\S \S 10$ e 11 deste artigo; b) a pessoa física, proprietária ou não, que explora atividade de extração mineral - garimpo, em caráter permanente ou temporário, diretamente ou por intermédio de prepostos, com ou sem o auxílio de empregados, utilizados a qualquer título, ainda que de forma não contínua; c) o ministro de confissão religiosa e o membro de instituto de vida consagrada, de congregação ou de ordem religiosa, quando mantidos pela entidade a que pertencem, salvo se filiados obrigatoriamente à Previdência Social em razão de outra atividade ou a outro regime previdenciário, militar ou civil, ainda que na condição de inativos; c) o ministro de confissão religiosa e o membro de instituto de vida consagrada, de congregação ou de ordem religiosa; e) o brasileiro civil que trabalha no exterior para organismo oficial internacional do qual o Brasil é membro efetivo, ainda que lá domiciliado e contratado, salvo quando coberto por regime próprio de previdência social; f) o titular de firma individual urbana ou 
Sobre tal diferenciação, transcrevemos a lição de Balera ${ }^{83}$ :

A previdência social é compulsória, instituída ope legis, e protege mesmo quem nela não confia ou quem nela não acredita (desde que atue em conformidade com o ordenamento jurídico). Por seu turno, a previdência privada é de índole contratual, negocial, engendrada e arrumada pelos interessados, constituída de forma autônoma em relação ao regime geral de previdência social. No negócio jurídico previdenciário privado vigora o princípio da autonomia privada.

Assim, ninguém pode ser compelido a aderir a um plano previdenciário privado, pois a sua contratação decorre da autonomia da vontade.

\subsubsection{Constituição de reservas}

\section{Um dos princípios que regem a previdência social é o da contributividade,} segundo o qual o indivíduo só se torna elegível a um benefício se houver contribuído para tanto.

rural, o diretor não empregado e o membro de conselho de administração de sociedade anônima, o sócio solidário, o sócio de indústria, o sócio gerente e o sócio cotista que recebam remuneração decorrente de seu trabalho em empresa urbana ou rural, e o associado eleito para cargo de direção em cooperativa, associação ou entidade de qualquer natureza ou finalidade, bem como o síndico ou administrador eleito para exercer atividade de direção condominial, desde que recebam remuneração; g) quem presta serviço de natureza urbana ou rural, em caráter eventual, a uma ou mais empresas, sem relação de emprego; h) a pessoa física que exerce, por conta própria, atividade econômica de natureza urbana, com fins lucrativos ou não; VI como trabalhador avulso: quem presta, a diversas empresas, sem vínculo empregatício, serviços de natureza urbana ou rural definidos no regulamento; VII - como segurado especial: o produtor, o parceiro, o meeiro e o arrendatário rurais, o pescador artesanal e o assemelhado, que exerçam essas atividades individualmente ou em regime de economia familiar, ainda que com auxílio eventual de terceiros, bem como seus respectivos cônjuges ou companheiros e filhos maiores de quatorze anos ou a eles equiparados, desde que trabalhem, comprovadamente, com o grupo familiar respectivo. II - como segurado especial: a pessoa física residente no imóvel rural ou em aglomerado urbano ou rural próximo a ele que, individualmente ou em regime de economia familiar, ainda que com o auxílio eventual de terceiros a título de mútua colaboração, na condição de: a) produtor, seja proprietário, usufrutuário, possuidor, assentado, parceiro ou meeiro outorgados, comodatário ou arrendatário rurais, que explore atividade: 1. agropecuária em área de até 4 (quatro) módulos fiscais; ou de seringueiro ou extrativista vegetal que exerça suas atividades nos termos do inciso XII do caput do art. 2o da Lei no 9.985, de 18 de julho de 2000, e faça dessas atividades o principal meio de vida; b) pescador artesanal ou a este assemelhado, que faça da pesca profissão habitual ou principal meio de vida; e c) cônjuge ou companheiro, bem como filho maior de 16 (dezesseis) anos de idade ou a este equiparado, do segurado de que tratam as alíneas a e b deste inciso, que, comprovadamente, trabalhem com o grupo familiar respectivo.

${ }^{83}$ Comentários à lei de previdência privada. São Paulo: Quartier Latin, 2005, p. 18. 
Nesse sentido é a doutrina de Sérgio Pinto Martins ${ }^{84}$ : “o regime previdenciário depende da contribuição por parte do próprio segurado, ao contrário do regime de assistência social, em que o segurado não precisa ter contribuído para ter direito ao benefício."

Tal característica é o que diferencia fundamentalmente a previdência da assistência social, pois nesta última a prestação de benefício independe de contraprestação $\operatorname{direta}^{85}$.

Embora sejam regimes autônomos, o princípio da contributividade rege também a previdência privada, o que significa que, se não houver contribuição, não haverá benefício.

Entretanto, nota-se uma importante diferença entre o regime financeiro do RGPS e RPPS com relação ao de previdência privada.

Nos primeiros, o modelo atuarial adotado, em regra geral, é o da repartição simples $^{86}$, no qual as contribuições da parcela ativa da população são destinadas ao pagamento dos benefícios dos inativos, não havendo individualização das reservas, nem mesmo a constituição de um "saldo de conta" em nome de cada segurado. Esse regime é conhecido pelo "pacto entre gerações", entendido como o procedimento por meio do qual uma geração financia os benefícios da outra.

Mas, na previdência privada, não é assim. Ela baseia-se na constituição de reservas, consoante o disposto no art. 202 da CF/88 e no art. $1^{\circ}$ da LC 109/01. Isso

${ }^{84}$ Direito da Seguridade Social. $21^{\mathrm{a}}$ Ed. São Paulo: Atlas, 2004, p. 302.

${ }^{85}$ Nos termos do art. $1^{\circ}$ da lei $n^{\circ} 8742 / 93$ : “A assistência social, direito do cidadão e dever do Estado, é Política de Seguridade Social não contributiva, que provê os mínimos sociais, realizada através de um conjunto integrado de ações de iniciativa pública e da sociedade, para garantir o atendimento às necessidades básicas.” (n.g.) Marcus Orione Gonçalves Correia e Érica Paula Barcha Correia esclarecem sobre este tema: "O custeio é outra característica fundamental e que na assistência social reveste-se de uma peculiaridade que a distingue da Previdência Social, em que o sistema é diretamente contributivo. Os benefícios assistenciais e os de saúde são custeados por toda a população e, portanto, de responsabilidade de toda a sociedade. Tal característica faz com que os benefícios assistenciais (sejam eles serviços, dinheiro ou utilidade), bem como os de saúde, v.g. campanhas de vacinação, sejam concedidos independentemente de contribuição por parte do respectivo beneficiário, o que os qualifica como não-contributivos." (Op. cit., p. 20)

86 "A previdência social brasileira se baseia no modelo de repartição simples, cuja lógica pressupõe um equilíbrio coletivo: as contribuições previdenciárias pagas pelos trabalhadores ativos destinam-se a cobrir os gastos com os benefícios dos inativos." (NAZBERG, Sheila; IKEDA Marcelo) Previdência no Brasil: Desafios $\quad e \quad$ Limites. $\quad$ Disponível em http://www.bndespar.gov.br/SiteBNDES/export/sites/default/bndes_pt/Galerias/Arquivos/conhecimento/livro /eco90_08.pdf>. Acesso em 26/12/13. 
significa que os recursos aportados nos planos destinam-se à constituição de uma reserva em nome de cada participante, como se fosse uma "poupança". Os recursos alocados nessas reservas (matemáticas) poderão servir para o pagamento dos benefícios.

As entidades de previdência privada ou seguradoras autorizadas a operar planos previdenciários privados deverão, portanto, para garantir suas obrigações perante os participantes, constituir reservas e provisões - as quais poderão ser, de maneira geral ${ }^{87}$, de dois tipos: provisões técnicas e reservas matemáticas.

José Vasques ${ }^{88}$ diferencia as provisões das reservas:

As provisões surgem muitas vezes, erradamente, referidas como reservas. As provisões são constituídas com um fim em vista e correspondem em geral a obrigações legais, enquanto as reservas se formam a partir dos lucros e constituem capital da própria empresa. (grifo do autor)

Neste mesmo sentido é a lição de Cristina Cantanhede Amarante Mano e Paulo Pereira Ferreira ${ }^{89}$ :

Não obstante a terminologia 'reserva técnica' ser a mais utilizada pela comunidade atuarial, a terminologia que atende aos princípios da contabilidade é 'provisão técnica', pois o termo 'reservas', na contabilidade, se aplica somente às chamadas reservas de capital, que se referem aos lucros acumulados na empresa e ainda não incorporados ao capital.

\subsubsection{Provisão técnica}

Conforme o conceito do dicionário Houaiss", provisão é a "reunião de coisas quaisquer destinadas ao uso futuro", "sortimento", "estoque". Embora a definição

\footnotetext{
${ }^{87}$ Dadas as limitações de escopo deste trabalho, iremos nos restringir a tratar, de maneira geral, da provisão técnica e da reserva matemática, destacando, contudo, que em termos técnico-atuariais e até mesmo contábeis existe um grande número de outras reservas e provisões, sobre as quais não nos aprofundaremos (v.g. provisão de prêmios, provisão de sinistros, provisão de IBNR, provisão para insuficiência de prêmios etc.). Sobre este tema, vide Cristina Cantanhede Amarante Mano e Paulo Pereira Ferreira (op. cit.).

${ }^{88}$ Contrato de Seguro - Notas para uma teoria geral. Coimbra: Coimbra Editora, 1999, p. 101.

${ }^{89}$ Op. cit. p. 4.
} 
provavelmente não tenha sido elaborada sob o enfoque da previdência privada, a ideia é comum: também nessa última há o acúmulo ou estoque de recursos destinados a uma necessidade futura.

Cristina Cantanhede Amarante Mano e Paulo Pereira Ferreira ${ }^{91}$ definem o que são provisões no âmbito das seguradoras e entidades de previdência privada:

As provisões técnicas são valores constituídos pelos empregados ou organizações ('empresas') cujo produto é o 'risco'. Estas empresas podem ser seguradoras, entidades de previdência privada aberta ou fechadas, entidades de capitalização, etc. e as provisões técnicas correspondem aos diversos compromissos financeiros futuros dessas empresas para com seus clientes ou participantes ('clientes'). Esses valores de provisões técnicas são, portanto, alocados no passivo dessas empresas e formados pelo excesso de valores pagos pelo cliente em relação aos riscos ou custos assumidos pela empresa. Esses compromissos futuros podem corresponder a valores já conhecidos ou, como acontece na maioria das vezes, corresponder a estimativas. Dessa forma, o cálculo das provisões técnicas deve ser feito necessariamente por um atuário, profissional que estabelece os limites de segurança na gestão dos riscos a partir do uso das teorias financeiras e das probabilidades.

Na mesma linha é a definição de Menezes Cordeiro", para quem “a ideia básica relativa às provisões técnicas é a seguinte: elas traduzem valores que devem ter um montante que permita, à seguradora, cumprir, na medida do razoavelmente possível, os compromissos resultantes dos contratos de seguros".

Conclui-se, assim, que as provisões técnicas situam-se em operações que têm por base o risco ${ }^{93}$, fundado em cálculo atuarial (embasado em teorias financeiras e em probabilidades). Prestam-se a garantir compromissos e obrigações futuras, assumidos pelas entidades ou seguradoras com relação aos participantes, segurados ou beneficiários a elas vinculados, referentes ao pagamento de indenização, em caso de ocorrência de um evento predeterminado.

\footnotetext{
${ }^{90}$ Disponível em: <http://houaiss.uol.com.br/busca?palavra=provis\%E3o>. Acesso em 02/09/13.

${ }^{91}$ Op. cit., p. 1.

92 CORDEIRO, António Menezes. Direito dos Seguros. Coimbra: Almedina, 2013, p. 327.

${ }^{93} \mathrm{O}$ risco aqui referido é o risco puro, e não o financeiro, sobre os quais discorreremos no Capítulo III, item 3.8.6.1.
} 
As provisões técnicas têm papel fundamental no âmbito da atividade das entidades ou seguradoras, não podendo nem estar superdimensionadas (para não comprometer a distribuição de lucros), nem ser subdimensionadas (o que poderia conduzir à insolvência). ${ }^{94}$

Por corresponderem a uma garantia prestada pela entidade ou seguradora e por serem a base sobre a qual se assenta o mutualismo ${ }^{95}$, não são passíveis de devolução aos segurados, ainda que o sinistro não venha a se materializar. Aí reside um dos fundamentos da comutatividade do contrato de seguro ${ }^{96}$.

\subsubsection{Reserva matemática}

A reserva matemática diferencia-se da provisão técnica, inicialmente, pela nomenclatura: é uma reserva, e não uma provisão ${ }^{97}$.

A necessidade de constituição ou não da reserva matemática emerge da forma como o custeio de um plano de previdência ou seguro é estruturado. No regime de repartição simples, adotado na maioria dos seguros de danos, em parte dos seguros de pessoas e também na previdência social, não há provisão de prêmios para exercícios futuros, devendo ser os mesmos suficientes apenas para cobrir os riscos daquele exercício. Os prêmios para os riscos assumidos nos exercícios subsequentes são revistos periodicamente em função do novo risco.

\footnotetext{
${ }^{94}$ Neste sentido, Cristina Cantanhede Amarante Mano; Paulo Pereira Ferreira, op. cit, p. 2.

${ }^{95}$ Mecanismo de repartição de riscos de natureza securitária, sobre o qual discorreremos no Capítulo III.

${ }^{96}$ Luiz Augusto Roux Azevedo explica: “A disposição legal a respeito do contrato de seguro distribui as prestações entre as partes, não havendo espaço para a noção de perda ou ganho. O segurado sabe a sua obrigação, consistente no pagamento do prêmio; ao segurador cumpre prestar a garantia durante a execução do contrato e, eventualmente, indenizar ou pagar ao segurado o capital garantido na hipótese de sinistro. Ao assim proceder, a lei brasileira dá especial ênfase ao caráter de garantia ao seguro, razão pela qual - e com o devido respeito às doutrinas dos mais influentes juristas brasileiros e estrangeiros - o contrato de seguro, sob a ótica da lei brasileira, deve ser considerado como um contrato comutativo." A comutatividade do contrato de seguro. (Dissertação de Mestrado em Direito Comercial). Faculdade de Direito da Universidade de São Paulo, São Paulo, 2010. Disponível em: <http://www.teses.usp.br/teses/disponiveis/2/2132/tde-25082011134415/pt-br.php>. Acesso em: 09/07/2013.

${ }^{97}$ Embora a nomenclatura não seja unânime, tendo se verificado o uso da expressão "provisão matemática", inclusive na regulamentação da Susep (v.g. Resoluções CNSP nº 139 e 140 de 2005).
} 
Já na previdência privada, estruturada no regime de capitalização, existe a formação de uma espécie de "poupança", constituída pelas contribuições aportadas, a qual que denominamos neste trabalho como reserva matemática.

Nas palavras de Rio Nogueira ${ }^{98}$ :

A reserva matemática de qualquer grupo segurado por uma entidade previdencial é a expressão monetária do direito líquido desse grupo perante a entidade em sua fase de funcionamento normal. Esse direito é variável no tempo, em dado instante é a diferença entre um crédito e um débito. $\mathrm{O}$ crédito é o dos compromissos futuros assumidos pela entidade em relação ao grupo na forma de promessa de benefícios. O débito é o dos compromissos futuros assumidos pelo grupo em relação à entidade, na forma de promessas de contribuições.

Para Jerônimo Jesus dos $\operatorname{Santos}^{99}$, as reservas matemáticas "correspondem à parcela de contribuição que não deve ser apropriada ou consumida por aquelas sociedades [as seguradoras], sob pena de desequilíbrio técnico das operações”.

Isso significa que a reserva matemática é um direito do participante. É o saldo que ele possui de crédito junto à entidade, constituído pelos aportes realizados por ele ou por terceiros $^{100}$, o qual não é passível de apropriação pela entidade e nem integra o mutualismo.

É um patrimônio que não se confunde, para fins de Direito, com o dos outros participantes. Se um indivíduo tem grande capacidade de poupar e realiza aportes vultosos em seu plano, e outro menos abastado não tem tanta disponibilidade financeira, aportando valores módicos, o saldo da reserva matemática de um em nada interfere no resultado do plano de um do outro, pois tais reservas são individualizadas ${ }^{101}$.

\subsection{Modalidades de planos de previdência privada}

\footnotetext{
${ }^{98}$ Reservas e Regimes Financeiros das Entidades Previdenciais. Rio de Janeiro: STEA, 2007, p. III.

${ }^{99}$ Lei da Previdência Complementar Comentada. Rio de Janeiro: Editora e Livraria Jurídica, 2004, p. 183.

${ }^{100}$ V.g. no caso dos planos coletivos instituídos, por exemplo, em que a pessoa jurídica contratando efetua aportes em nome das pessoas físicas que com ela se relacionam.

${ }^{101}$ Com exceção dos planos BD.
} 
Para tratar dos aspectos jurídicos dos planos de benefícios das entidades de previdência, é oportuno considerar a forma de estruturação de cada uma de suas espécies.

Não se pretende neste trabalho, por uma questão de delimitação do objeto do estudo, aprofundar em questões técnicas, de modo que as três modalidades em que os planos de benefícios podem ser estruturados, conforme a concepção atuarial, serão analisadas sucintamente: $\mathrm{BD}, \mathrm{CD}$ e $\mathrm{CV}$. Veremos, mais adiante, que a estruturação técnica dos planos também será decisiva para que se possa atingir a natureza jurídica da reserva matemática.

\subsubsection{Planos de benefício definido (BD)}

Os planos de benefício definido foram os primeiros a surgir no mercado de previdência privada brasileiro $^{102}$.

Conforme a definição regulamentar ${ }^{103}$, são aqueles em que "o valor do benefício, pagável de uma única vez ou sob a forma de renda, e das respectivas contribuições são estabelecidos previamente na proposta de inscrição."

Segundo o magistério de Adacir Reis ${ }^{104}$ :

[...] é aquele no qual o participante sabe de antemão o quanto receberá de benefício, embora não saiba exatamente o quanto vai pagar, já que esse valor poderá variar de acordo com o plano anual de custeio, podendo diminuir ou aumentar a contribuição a partir da constatação de superávit (art. 20) ou déficit (art. 21). Em outras palavras, no plano de benefício definido a contribuição é indefinida, mas o valor do benefício é

102 "Na origem, os planos oferecidos pelas entidades fechadas, em todo o mundo, eram do tipo BD e, no Brasil, não se discrepou. Pretendia-se que o Primeiro Pilar proporcionasse valor certo, mas com limite máximo, e os fundos de pensão complementassem a renda na inatividade até determinado patamar." (Flavio Martins Rodrigues) Previdência complementar: conceitos e elementos jurídicos fundamentais. In Revista de Previdência da UERJ, n. 3. Rio de Janeiro: Gramma, 2005, p. 10.

${ }^{103}$ Resolução CNSP n ${ }^{\circ} 139 / 05$, art. 8, II e Resolução CNSP n ${ }^{\circ} 140 / 05$, art. $8^{\circ}$, II.

${ }^{104}$ REIS, Adacir. (Org.) Fundos de pensão em debate. Brasília: Brasília Jurídica, 2002, p. 20. 
previamente definido na data de vinculação do participante ao plano, calculado com base em regras estipuladas em regulamento e geralmente vinculadas ao salário da ativa ou à média extraída de um período de contribuição que antecede a aposentadoria. No plano BD os cálculos são feitos levando em conta o total da massa de participante. Existe aqui o chamado 'mutualismo'.

Sua principal característica advém do próprio nome: são planos em que o valor do benefício a ser recebido no futuro já é previamente definido pelas partes no início da relação. Em outras palavras, ao ingressar no plano, o participante projeta o valor do benefício que anseia atingir.

A partir dessa meta, a entidade o direciona, por meio de cálculos atuariais e financeiros, estabelecendo o valor de contribuição ideal, variável periodicamente conforme as oscilações das bases técnicas ${ }^{105}$. Os aportes a estes planos são capitalizados, de modo que, se todas as premissas adotadas forem observadas, será possível atingir o valor do benefício pretendido, no futuro.

Nos planos de benefício definido, do ponto de vista jurídico, pode-se afirmar que existe uma obrigação de "fim" ou de "resultado" por parte da entidade de previdência, a qual se compromete, mediante o recebimento das contribuições, a efetuar o pagamento de um dado valor de benefício quando vencido o período de diferimento. A entidade, assim, assume um duplo risco: atuarial ("risco puro") e financeiro ("risco especulativo") 106.

O risco atuarial ${ }^{107}$ está intimamente ligado à expectativa de sobrevivência ou de mortalidade, ou seja, um participante ter sua longevidade superior àquela que a entidade havia previsto, por meio de cálculos atuariais, ou sua mortalidade abreviada com relação ao padrão.

\footnotetext{
${ }^{105}$ Ana Paula Quelhas pontua os parâmetros que condicionam a base técnica de um plano BD: modo de determinação do benefício futuro; salários futuros e ano de quotização; tábuas demográficas; taxas de juros técnicos usadas na valorização de ativos do fundo; fórmulas de determinação do custo do plano; das provisões e de eventuais desvios; indicação dos excedentes oriundos dos desvios positivos e do modo de financiamento dos desvios negativos. Seguros de Vida e Fundos de Pensão - uma perspectiva financeira e atuarial. Coimbra: Almedina, 2010, p. 400.

${ }^{106}$ Vide item 3.8.6.1.

${ }^{107}$ Para José Ângelo Rodrigues, o risco atuarial consiste na "possibilidade de as premissas assumidas pelo atuário para eventos de mortalidade, invalidez e morbidez dos participantes não se realizarem como previsto". Gestão de risco atuarial. São Paulo: Saraiva, 2008, p. 28.
} 
Tal risco está intimamente relacionado com o conceito de mutualismo, já que o participante, mediante o pagamento de suas contribuições, procura garantir ${ }^{108}$ que as consequências econômicas do risco relacionado com sua morte ou sobrevivência serão compensadas economicamente pela entidade de previdência privada, em um mecanismo assemelhado a um contrato de seguro. Nesse sentido:

\begin{abstract}
Num plano de benefício definido, o patrimônio acumulado com as contribuições dos empregados e dos empregadores não é alocado em contas individuais, mas compõe um plano mutualista em que o valor do benefício é uma variável independente, previamente estabelecido pelo regulamento do plano, e a contribuição, uma variável dependente, que fica em aberto, sendo determinada anualmente pelo plano de custeio, de forma suficiente para financiar os benefícios futuros. O plano de benefício definido possui um grau de complexidade na sua estruturação, na medida em que assegura um valor final de benefício independente das oscilações nas hipóteses demográficas e econômicas escolhidas, e incidentes sobre o regime de capitalização, implicando em aumentos ou reduções na taxa de contribuição dentro do custeio do plano. ${ }^{109}$ (n.g.)
\end{abstract}

A entidade, por meio do mutualismo, busca reduzir sua probabilidade de perda financeira relacionada com a morte ou sobrevivência do participante, o que só se torna possível se houver uma massa de participantes em que se possa assentar o equilíbrio do plano.

Por essa razão, é possível afirmar que os planos de beneficio definido, assim como os contratos de seguros, têm seu equilíbrio atuarial calcado no mutualismo, e que é imprescindível o pagamento do prêmio ou da contribuição, para a constituição da provisão técnica capaz de garantir o adimplemento das obrigações assumidas.

Tanto é que a doutrina italiana esclarece que a forma de BD é utilizada para coberturas de risco, as quais são prestações tipicamente de seguros. E, como decorrência,

\footnotetext{
${ }^{108}$ Comumente observa-se o uso da expressão "transferência do risco" no que toca ao contrato de seguro. Na realidade, como esclarece Vera Helena de Mello Franco (Contratos no direito privado. $3^{\mathrm{a}}$ ed. São Paulo: Revista dos Tribunais, 2012, p. 291), “o risco não se transfere para a seguradora. A seguradora não assume o risco, já que isto daria lugar a um novo risco, a saber: o da insolvência da seguradora. Ela apenas garante que as consequências do eventual sinistro (ocorrência do risco) que se quer evitar serão compensadas economicamente. A sua prestação é uma prestação de segurança, de garantia."

${ }^{109}$ SANTOS, Jordanno Brunno Nicoletta dos. Desenvolvimento de métodos alternativos para avaliação de riscos segundo o conceito de supervisão baseada em riscos. 2011. Dissertação (Mestrado em Sistemas Eletrônicos) - Escola Politécnica, Universidade de São Paulo, São Paulo, 2011. Disponível em: <http://www.teses.usp.br/teses/disponiveis/3/3142/tde-03042012-080226/>. Acesso em: 05/01/2014.
} 
naquele país ${ }^{110}$ tais coberturas somente podem ser contratadas com seguradoras - seja quando oferecidas por entidades de previdência privada abertas, seja quando oferecidas por fundos de pensão ${ }^{111}$ (conforme o art. 6 $3^{\circ}$ co. D. Lgs n 124 del 1993).

O outro risco a que ficam sujeitos os planos de benefício definido é o financeiro, assim entendido como o risco inerente a qualquer tipo de investimento - se houver má gestão, ou se o mesmo não for bem sucedido, o resultado será negativo. Se, por outro lado, for um investimento de sucesso, o resultado será positivo. Assim, de uma forma ou de outra, os valores alocados na aplicação serão afetados.

Do ponto de vista dos participantes, pode ser interessante a opção pela aquisição de uma renda vitalícia ou por invalidez ${ }^{112}$, por garantir um valor predeterminado, conhecido, certo e pelo tempo de duração da vida. Mas é certo que, pelo duplo risco assumido pela entidade ao prometer tal quantia, o valor do benefício poderá ser financeiramente menos interessante, pois a entidade precificará o valor do risco que avoca, repassando-o aos participantes.

Os planos oferecidos atualmente pelas entidades abertas brasileiras ${ }^{113}$ somente oferecem a cobertura de BD quando (i) o participante opta pela contratação, paralela à do plano de acumulação, de uma cobertura de risco ${ }^{114}$ ou (ii) após o período de diferimento, opta por converter seu saldo de conta acumulado em uma renda vitalícia. Nesta hipótese, a entidade aplicará critérios atuariais à reserva matemática acumulada, para calcular o valor do benefício.

\subsubsection{Planos de contribuição definida (CD)}

\footnotetext{
${ }^{110}$ No Brasil, entretanto, as próprias entidades podem operacionalizar as coberturas de risco.

111 ALPA, Guido (coord.) Giurisprudenza sistematica di diritto civile e commerciale. Torino: UTET giuridica, 2006, p. 2814.

${ }_{112}$ Estruturadas na forma de benefício definido

${ }^{113}$ Notadamente o PGBL e VGBL.

${ }^{114}$ V.g. cobertura por invalidez, renda vitalícia ao beneficiário, dentre outras.
} 
Os planos de contribuição definida surgiram no Brasil após a década de 80, como uma alternativa menos arriscada para as entidades do que os planos $\mathrm{BD}$, por não serem planos calcados em fatores atuariais, mas sim exclusivamente financeiros.

Os planos de BD eram vistos, conforme definição de Kaizô Iwakami Beltrão e Sonoe Sugahara Pinheiro ${ }^{115}$, como uma "herança obsoleta" dos anos 40 e 50, que não acompanhou a nova realidade econômica e demográfica.

Nos planos CD, o participante estabelece de antemão o valor de sua contribuição (que é definida no momento da contratação), mas não consegue precisar qual será o valor acumulado ao longo da execução do contrato. Portanto, o valor do seu benefício somente será definido posteriormente, pois dependerá da reserva matemática constituída, fruto do pagamento de suas contribuições.

Ao término do período de diferimento, o participante poderá converter seus recursos em uma renda por tempo determinado ${ }^{116}$, tendo a liberdade para escolher o prazo mais conveniente e adequado ao seu perfil ${ }^{117}$.

Conforme a doutrina de Rio Nogueira ${ }^{118}$ :

Em tal processo, a administradora de fundos não assume obrigações formais quanto aos valores do pecúlio e da prestação inicial das rendas, que serão invariavelmente ajustados ao realizado pela capitalização dos depósitos. Ali, não há preocupação com reservas para os benefícios a conceder, e os eventuais déficits estarão vinculados exclusivamente à má gestão ulterior dos fundos garantidores das aposentadorias e pensões concedidas. Tal, a indiscutível vantagem que atualmente se apresenta às empresas interessadas na proteção securitária supletiva dos seus empregados - o descomprometimento formal com os níveis iniciais dos benefícios futuros. (grifos do autor)

Logo, o risco deste tipo de plano, para a entidade, restringe-se ao "financeiro", não havendo risco atuarial ("puro").

\footnotetext{
${ }^{115}$ Op. Cit., p. 39.

${ }^{116}$ Em que não há a aplicação de fatores atuariais.

${ }^{117}$ Destacamos, todavia, que existem no mercado brasileiro os chamados "planos mistos" que permitem que a acumulação seja realizada como um plano de $\mathrm{CD}$, e o benefício em BD.

${ }^{118}$ Benefícios previdenciais. Os isógonos e a ética securitária. Rio de Janeiro: STEA, 2002, p. 146.
} 
Especialmente no momento presente, em que a expectativa de sobrevivência da população vem crescendo em marcha contínua, é cada vez mais difícil precisar qual será a expectativa de vida das pessoas no futuro. Por essa razão, tais planos, juntamente com os de contribuição variável (infra, item 1.6.3), vêm conquistando significativo espaço no mercado de previdência privada brasileiro ${ }^{119}$.

A obrigação da entidade é de meio, e não de resultado (como nos planos de BD). Os planos $\mathrm{CD}$, assim, são mais seguros e não representam tanta ameaça à solvência das entidades, uma vez que suas responsabilidades ficam adstritas aos valores aportados.

Se tais planos, por um lado, aliviam a pressão do risco sobre as entidades, por outro esse risco passa a recair sobre os próprios participantes, como afirmam Kaizô Iwakami Beltrão e Sonoe Sugahara Pinheiro ${ }^{120}$ :

Enquanto o plano do tipo BD apresenta um caráter mutualista, em que eventuais insuficiências de recursos recaem sobre os planos e não sobre o participante, o plano do tipo $\mathrm{CD}$ tem caráter individualista, em que o risco é todo do participante.

Não há mutualismo nesses planos, uma vez que o único risco existente é o financeiro, ou seja, o risco de má gestão ou do retorno dos investimentos não corresponder ao que se esperava. $\mathrm{O}$ participante assume tais riscos tal como seria em outra modalidade de investimento, como em um fundo, por exemplo. Se sua longevidade for superior às reservas acumuladas, terá de suportar o risco da falta de recursos sem o suporte da entidade.

\footnotetext{
${ }^{119}$ No caso das entidades fechadas, é nítido o crescimento. Em 1993, 70\% dos planos oferecidos pelos fundos de pensão brasileiros eram de BD, $10 \%$ de CD e $20 \%$ de CV. Em 2013, só 30\% dos planos eram de BD, e os outros $70 \%$ eram divididos em partes praticamente iguais entre os planos de CD e CV. Fonte: Estatística Trimestral - Junho 2013, PREVIC, disponível em <http://www.previdencia.gov.br/arquivos/office/27_130918-144618-878.pdf>, acesso em 26/12/13. No caso das entidades abertas, os planos que dominam o mercado - PGBL e VGBL, são estruturados como CV, e os planos de BD só existem para concessão de benefícios de risco, tais como as coberturas por invalidez, renda vitalícia e pecúlios. Com relação aos planos das entidades abertas, Léo do Amaral Filho pontua: "A capitalização é característica marcante que os planos das entidades abertas ganharam no mundo empírico. Estas podem, entretanto, criar planos destinados ao pagamento de benefícios definidos (predeterminados), cuja característica é a repartição. A dinâmica do mercado atual dirige para a formação de planos de capitalização. Tal se deve ao custo que a repartição acarreta, e que cada vez mais se acentua, em decorrência, sobretudo, de redução do crescimento populacional.” Previdência Privada Aberta. São Paulo: Quartier Latin, 2005, p. 305.

${ }^{120}$ Estimativas de mortalidade para a população coberta pelos seguros privados. Texto para discussão $\mathrm{n}^{\circ}$ 868. Rio de Janeiro, ano de 2002. Disponível em: 〈http://www.ipea.gov.br >. Acesso em: 12/10/13.
} 
Fabiana Lopes da Silva ${ }^{121}$, sobre este assunto, explica:

\begin{abstract}
Nos planos CD puros, as reservas são individualizadas e não há a figura do mutualismo, o que faz com que o plano seja mais caro (valor maior das contribuições) que os planos de BD. Assim, no plano $\mathrm{CD}$, o benefício é em função do saldo de contas acumulado pelo participante, ou seja, o benefício é a variável dependente e a contribuição a variável independente em que o benefício varia de acordo com o montante de recursos acumulados, que por sua vez, depende da rentabilidade alcançada pelos investimentos feitos com as contribuições do participante. (n.g.)
\end{abstract}

\title{
1.6.3. Planos de contribuição variável (CV)
}

Os planos estruturados na modalidade de contribuição variável são aqueles em que:

[... ] o valor e o prazo de pagamento de prêmios podem ser definidos previamente e o capital segurado, pagável de uma única vez ou sob a forma de renda, por ocasião da sobrevivência do segurado ao período de diferimento, é calculado com base no saldo acumulado da respectiva provisão matemática de benefícios a conceder e no fator de cálculo ${ }^{122}$.

Assemelham-se aos planos de $\mathrm{CD}$, pois também não são calcados em cálculos atuariais na fase de acumulação, em que não há o "risco puro", nem mutualismo entre os participantes, e a obrigação da entidade também é apenas de meio. A diferença entre eles é que, nos planos de CV, o valor da contribuição varia conforme a conveniência do participante, ao passo que nos de CD a contribuição é fixa.

Mas não é só isso. Os planos de CV são peculiares por conjugarem características de CD na fase de acumulação e de BD na fase de concessão de renda. É assim que define, Jordanno Brunno Nicoletta dos Santos ${ }^{123}$ :

\footnotetext{
${ }^{121}$ Impacto do risco de longevidade em planos de previdência complementar. 2010. Tese (Doutorado em Controladoria e Contabilidade: Contabilidade) - Faculdade de Economia, Administração e Contabilidade, Universidade de São Paulo, São Paulo, 2010. Disponível em: <http://www.teses.usp.br/teses/disponiveis/12/12136/tde-29112010-182036/>. Acesso em: 05/04/13.

${ }^{122}$ Conforme o art. $8^{\circ}$, I da Resolução CNSP n ${ }^{\circ}$ 140/05 e art. $8^{\circ}$, I da Resolução CNSP no 139/05.

${ }^{123}$ Op. cit, p. 26.
} 
Modelo de plano cujos benefícios programados apresentam a conjugação das características das modalidades de Contribuição Definida e Benefício Definido, no qual a poupança acumulada e seus rendimentos determinarão o valor do benefício até o participante atingir a idade de aposentadoria, sendo que, a partir daí, o valor de benefício continua sendo pago, porém conforme características de um Benefício Definido.

Ou seja, são planos em que a natureza da obrigação da entidade varia conforme o momento: durante a fase de acumulação, a obrigação da entidade é de meio, pois se restringe à devolução dos valores que a ela foram confiados. Durante a fase de concessão do benefício (se o participante chegar a atingi-la), a reserva matemática converte-se em provisão técnica; o risco, que era somente financeiro, passa a ser também atuarial; faz-se presente o mutualismo; e a obrigação da entidade passa a ser de resultado.

Dadas as peculiaridades deste tipo de plano, o qual apresenta uma dupla feição, é que se justifica também a restrição da abordagem deste trabalho à reserva matemática e, portanto, à primeira etapa do plano de $C V$.

\subsection{Tipos de planos oferecidos no mercado brasileiro}

\subsubsection{PGBL e VGBL}

Os principais protagonistas do mercado de previdência privada aberta brasileiro ${ }^{124}$ são o Plano Gerador de Benefício Livre (PGBL) ${ }^{125}$ e o Vida Gerador de Benefício Livre $(\text { VGBL })^{126}$, sendo que a carteira de investimentos do primeiro representa $8,71 \%$ do

\footnotetext{
${ }^{124}$ Destacamos o PGBL e o VGBL por serem os planos que praticamente dominam o mercado. Há ainda outros planos, tais como o FGB (Fundo Garantidor de Benefícios) PAGP (Plano com Atualização Garantida e Performance), PRGP, (Plano com Remuneração Garantida e Performance), PRSA (Plano com Remuneração Garantida e Performance sem Atualização), PRI (Plano de Renda Imediata), VAGP (Vida com Atualização Garantida e Performance), VRGP (Vida com Remuneração Garantida e Performance), VRSA (Vida com Remuneração Garantida e Performance sem Atualização) e VRI (Vida com Renda Imediata), além dos planos tradicionais. Contudo, conforme dados da FENAPREVI, a receita dos planos tradicionais somada à dos demais produtos não chega a $2 \%$ da receita global dos produtos de previdência privada oferecidos no mercado, razão pela qual optamos por excluí-los deste trabalho. Fonte: Dados estatísticos Planos de Caráter Previdenciário - Junho 2013 - FENAPREVI, disponível em <http://www.cnseg.org.br/fenaprevi/estatisticas/estatisticas.html>. Acesso em: 22/09/2013.

${ }^{125}$ Regulamentado no âmbito infralegal pela Resolução CNSP n ${ }^{\circ}$ 139/05 e Circular SUSEP no 338/07.

${ }^{126}$ Regulamentado no âmbito infralegal pela Resolução CNSP n ${ }^{\circ}$ 140/05 e Circular SUSEP nº 339/07.
} 
mercado brasileiro, e a do segundo é o carro-chefe, abrangendo $86,9 \%$ dos recursos do setor $^{127}$.

Ambos caracterizam-se por serem planos de acumulação ${ }^{128}$, estruturados na modalidade de contribuição variável ${ }^{129}$, oferecendo ao participante a possibilidade, ao término do período de diferimento, de contratação de uma renda ${ }^{130}$.

Tanto no PGBL quanto no VGBL o principal atributo é a "acumulação", e não o estabelecimento de critérios atuariais ou o compartilhamento de riscos entre a massa de participantes. Isso porque, além de tais planos serem estruturados como CD na fase de acumulação, seu principal apelo comercial é de investimento ou até mesmo de um sorteio

\footnotetext{
${ }^{127}$ Fonte: Dados estatísticos - Planos de Caráter Previdenciário - Junho 2013 - FENAPREVI, disponível em <http://www.cnseg.org.br/fenaprevi/estatisticas/estatisticas.html>. Acesso em: 24/09/13.

${ }^{128}$ Não se confundindo com coberturas de risco.

${ }^{129}$ Conforme art. $7^{\circ}$, I, da Resolução SUSEP n ${ }^{\circ}$ 139/04: "Em função da cobertura por sobrevivência, os planos serão dos seguintes tipos: I - Plano Gerador de Benefício Livre (PGBL), quando, durante o período de diferimento, a remuneração da provisão matemática de benefícios a conceder for baseada na rentabilidade $\mathrm{da}(\mathrm{s})$ carteira(s) de investimentos de $\mathrm{FIE}(\mathrm{s})$, no(s) qual(is) esteja(m) aplicada(s) a totalidade dos respectivos recursos, sem garantia de remuneração mínima e de atualização de valores e sempre estruturados na modalidade de contribuição variável." E também o art. $7^{\circ}$ da Resolução SUSEP n ${ }^{\circ}$ 140/04: "Os planos serão dos seguintes tipos: I - Vida Gerador de Benefício Livre (VGBL), quando, durante o período de diferimento, a remuneração da provisão matemática de benefícios a conceder for baseada na rentabilidade da(s) carteira(s) de investimentos de FIE(s), no(s) qual(is) esteja(m) aplicada(s) a totalidade dos respectivos recursos, sem garantia de remuneração mínima e de atualização de valores e sempre estruturados na modalidade de contribuição variável." (n.g.)

${ }^{130}$ V.g. Renda vitalícia, por prazo certo, reversível ao beneficiário, conforme previsto no Regulamento do plano.
} 
de título de capitalização ${ }^{131}$. Há liquidez dos recursos e ampla flexibilidade para o resgate dos valores acumulados ${ }^{132}$, tal como ocorre em outros produtos financeiros.

Ademais, o "saldo de conta" acumulado por um participante não interfere no valor do benefício ou das reservas de outro participante, pois não há mutualismo entre eles.

Por serem o PGBL e o VGBL planos de CV, a obrigação da entidade durante a fase de diferimento é de meio, não havendo promessa de resultado, assim entendido como o pagamento de algum valor fixo em forma de renda. A medida da obrigação da entidade é a reserva matemática acumulada pelo participante.

É comum que os participantes sequer cheguem a contratar a renda vitalícia, optando por deixar os recursos aportados no plano, como se fossem um investimento qualquer $^{133}$, fazendo resgates periódicos do saldo da reserva matemática ${ }^{134}$ ou, ainda, direcionando a reserva para fins sucessórios.

131 A título de exemplificação, foram pesquisadas as seguintes propagandas na rede mundial de computadores: "O Santander Prev Premiada é um produto de previdência no qual você concorre a sorteios mensais no valor de $\mathrm{R} \$ 70.000,00$ líquidos, durante 12 meses, sem nenhum custo adicional, além de todos os benefícios de um plano de previdência. A cada R \$ 1.000,00 aplicados no Santander Prev Premiada, você terá direito a 4 números da sorte para concorrer aos sorteios mensais. Quanto maior a aplicação, mais números você receberá e conseqüentemente, maiores serão as chances de ganhar. Aproveite esta oportunidade e contrate o Santander Prev Premiada até dez/11. Se você fizer novos aportes no plano durante o ano de 2012, receberá mais números da sorte para concorrer aos sorteios." (n.g.) Poupança premiada. Disponível

<http://www.santander.com.br/portal/wps/script/templates/GCMRequest.do?page=5793\&entryID=6617>, acesso em 01/12/20. "Os planos de previdência do Citi estão disponíveis nas modalidades PGBL e VGBL, que são as mais modernas do mercado. Elas oferecem as vantagens fiscais dos planos de previdência, mais a flexibilidade e a rentabilidade dos fundos de investimento. Ao contrário dos planos tradicionais, os planos PGBL e VGBL não têm garantia mínima de rentabilidade e são bem mais transparentes.

Outra vantagem é permitir ao participante escolher em que fundo quer aplicar seus recursos, além da periodicidade e do valor das contribuições. Também é possível acompanhar diariamente, pela imprensa, a evolução do fundo onde o dinheiro está. E mais: após 60 dias de carência, você pode resgatar ou interromper temporariamente o plano, sem que ele seja cancelado." Planos PGBL/VGBL. Disponível em <https://www.citibank.com.br/investimentos/previdencia/planos_pgbl_vgbl.html>, acesso em 01/11/13.

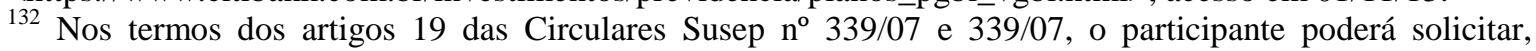
independentemente do número de contribuições pagas, resgate parcial ou total, de recursos do saldo da reserva matemática de benefícios a conceder, após o cumprimento de período de carência, que deverá estar compreendido entre 60 (sessenta) dias e 24 (vinte e quatro) meses, a contar da data de protocolo da proposta de contratação do plano.

${ }^{133}$ Neste sentido é a reportagem da Revista Cobertura "Com juros baixos, renda vitalícia é o grande desafio para a previdência privada". (ALCOVA, Camila) Disponível em: <http://www.revistacobertura.com.br/lermais_materias.php?cd_materias=89192>. Acesso em: 06/09/13.

${ }^{134}$ Sobre este assunto, Eduardo Fraga Lima de Melo e Mariana Arozo Benício de Melo esclarecem: "Neste tipo de pagamento [resgate programado], ao invés da renda ser calculada por um "fator atuarial", os pagamentos são retirados periodicamente da conta individual do participante no valor que lhe interessa. A conta individual permanece aplicada no fundo de investimento do período de diferimento, o participante não passa a ser considerado assistido formalmente, como o que ocorre na conversão em renda. Um dos motivos 
A respeito da diferença entre o PGBL e o VGBL, pode-se sintetizar que é essencialmente tributária: o primeiro tem característica de plano, e submete-se a um regime fiscal semelhante ao dos fundos de pensão, permitindo que o participante deduza até $12 \%$ da renda bruta anual, conforme o valor das contribuições efetuadas ao plano ${ }^{135}$. O PGBL é indicado somente para pessoas que declaram o imposto de renda no formulário completo e são vinculadas ao RGPS ou ao RPPS - condições estabelecidas por lei ${ }^{136}$ para que possam desfrutar do benefício fiscal. A tributação incide sobre o valor total do resgate ou do benefício, ou seja, o valor aportado (descontados eventuais carregamentos ${ }^{137}$ ou taxas administrativas ${ }^{138}$ ), acrescido da rentabilidade obtida durante o período do investimento, se houver.

Já o VGBL foi estruturado como um "seguro de vida com cobertura por sobrevivência"139 e, por essa razão, recebe tratamento tributário diferenciado. O participante, aqui também chamado de "segurado", não pode deduzir o valor das contribuições efetuadas ("prêmios") de sua base de cálculo para o imposto de renda, como ocorre no PGBL, já que a tributação de "seguros" é diferente da aplicável aos planos de benefícios. Por outro lado, há uma vantagem nestes produtos, que é o fato da tributação sobre os benefícios e os resgates incidir tão somente sobre o valor dos rendimentos obtidos, não atingindo o valor aportado - tributação típica dos investimentos.

Os recursos dos planos - tanto do PGBL quanto do VGBL - são investidos em FIEs (Fundos de Investimento Especialmente constituídos), de titularidade $^{140}$ da

para a escolha desta modalidade de pagamento pode ser o fato de o resíduo do fundo ser pago aos seus beneficiários em caso de morte do participante durante os resgates programados. $\mathrm{Na}$ anuidade vitalícia, por exemplo, após a morte do assistido, o fundo residual não é pago a mais ninguém. Outro possível motivo pode ser a diferença de rentabilidade entre o fundo utilizado durante o período de contribuições e o utilizado no período de concessão de benefícios." (Dilema da Conversão em Renda: Resgates Programados $\times$ Anuidade Vitalícia in Revista Brasileira de Risco e Seguros. v. 5, n. 9, abr./set. Rio de Janeiro: Funenseg, 2009, p. 46)

${ }^{135}$ Nos termos do art. 11 da Lei no 9.532/97 e alínea "e" do inciso II do art. $8^{\circ}$ da Lei no 9.250/95.

${ }^{136}$ Conforme o art. 11 da Lei $n^{\circ}$ 9.532/97 e alínea "e" do inciso II do art. $8^{\circ}$ da Lei no 9.250/95.

${ }^{137}$ Remuneração pelos serviços prestados pela seguradora.

${ }_{138}$ Remuneração pelos serviços prestados pelo fundo de investimento que administra as reservas do plano.

${ }^{139}$ A nomenclatura "seguro de vida com cobertura por sobrevivência", em nosso entender, não é adequada, uma vez que este produto não é verdadeiramente um seguro por lhe faltarem elementos que são imprescindíveis para a configuração de um contrato de seguro, a respeito dos quais discorreremos no Capítulo III.

${ }^{140}$ Entretanto, Pedro Jesús Baena Baena sustenta que há um efetivo direito de propriedade dos participantes e segurados sobre a reserva matemática. Para o doutrinador espanhol, o pagamento de contribuições de previdência privada ou de prêmios nos seguros que preveem resgate não daria lugar à constituição de um depósito, mas ao nascimento de uma relação obrigatória derivada do contrato. Como contrapartida pelo 
seguradora ou entidade de previdência privada, os quais são definidos nos termos da Resolução CNSP nº 139/05 e 140/05 como:

[...] fundo de investimento especialmente constituído ou fundo de investimento em quotas de fundo de investimento especialmente constituídos, cujos únicos quotistas sejam, direta ou indiretamente, sociedades seguradoras e entidades abertas de previdência complementar ou, no caso de fundo com patrimônio segregado, segurados e participantes de planos VGBL - Vida Gerador de Benefício Livre ou PGBL - Plano Gerador de Benefício Livre. (n.g.)

\subsubsection{FAPI}

Dedicaremos, por fim, algumas linhas para explicar outro plano que, embora seja atualmente de pouca comercialização e expressividade no Brasil ${ }^{141}$, possui uma lógica que nos permite compreender os planos de acumulação em que não há risco atuarial para a entidade.

pagamento do prêmio, a seguradora seria devedora de prestação que consiste na devolução dos valores que a ela foram confiados (El derecho de rescate de la provisión matemática des seguro de vida. Valencia: Tirant le Blanch, 2008, p. 45). Por outro lado, José Luis Maestro Martinez defende que a propriedade dos recursos da reserva matemática é da seguradora, por se assemelhar a operação previdenciária e securitária a um depósito irregular: "O direito de resgate que concede ao tomador a Lei de Contrato de Seguro tem por causa a reserva matemática, que, por sua vez, representa o valor da obrigação que para com o tomador tem a seguradora por razões de prêmios satisfeitos por este. Embora tradicionalmente, para se referir ao tipo de direito que o tomador tem sobre a provisão, vem-se dizendo que esta é de propriedade daquele, sua natureza jurídica se assemelha melhor à de um depósito irregular, como é o de dinheiro ou de outra coisa fungível, em que o depositante perde a propriedade do que entregou ao depositário, adquirindo em contrapartida, um direito de crédito para que lhe devolvam do mesmo tipo e qualidade, acrescentando-se, neste caso, os rendimentos resultantes do investimento da reserva aos juros técnicos garantidos." (Tradução livre) "El derecho de rescate que concede al tomador la Ley de Contrato de Seguro trae su causa de la provisión matemática, la cual, a su vez, representa el valor de la obligación que para con el tomador tiene la entidad aseguradora por razón de las primas satisfechas por éste. Aunque tradicionalmente, para referirse al tipo de derecho que el tomador ostenta sobre la provisión, se ha venido diciendo que ésta es propiedad de aquél, su naturaleza jurídica se asimila más bien a la de un depósito irregular, como es el de dinero u otra cosa fungible, en cual el depositante pierde la propiedad de lo entregado as depositario, adquiriendo a cambio, un derecho de crédito a que se le devuelva otro tanto de la misma especie y calidad; incrementado, además, en este caso, por los rendimientos que resulten de la inversión de la provisión al interés técnico garantizado." (Provisiones matemáticas y rescates en el ROSSP. Disponível em: <http://www.mapfre.com/documentacion/publico/i18n/catalogo_imagenes/grupo.cmd?path=102830>. Acesso em 02/06/12)

${ }^{141}$ Conforme estatísticas da Fenaprevi (Federação Nacional de Previdência Privada e Vida), as reservas dos FAPIs representam apenas $0,15 \%$ dos recursos totais dos planos previdenciários fechados das entidades abertas. (Fonte: Previdência Complementar recebe $R \$ 4,3$ bi em novos aportes em agosto, disponível em $<$ http://www.cnseg.org.br/fenaprevi/servicos-apoio/noticias/previdencia-complementar-recebe-r-4-3-bi-emnovos-aportes-em-agosto.html>, acesso em 05/01/14. 
Os FAPIs (Fundo de Aposentadoria Programada Individual) foram regulamentados pela lei ${ }^{\circ}$ 9477/97, cuja definição está no parágrafo primeiro do seu art. $1^{\mathrm{o}}$ :

Os Fundos de Aposentadoria Programada Individual - FAPI, constituídos sob a forma de condomínio aberto, terão seus recursos aplicados de acordo com o que vier a ser determinado pelo Conselho Monetário Nacional.

Esses planos possuem as mesmas características tributárias dos PGBLs ${ }^{142}$, mas apresentam uma peculiaridade: neles, não há a possibilidade de conversão do capital acumulado em renda ${ }^{143}$. Os recursos aportados são resgatados pelos participantes conforme suas conveniências e periodicidade escolhida. Como não é oferecida nenhuma cobertura de risco atrelada ao plano de acumulação, não há risco atuarial ("risco puro") ${ }^{144}$.

Logo, esse tipo de plano definitivamente não se confunde com um seguro. Tanto é que pode ser comercializado até mesmo por instituições financeiras, independentemente da participação de seguradoras, como dispõe o art. $3^{\circ}$ da referida lei:

Os Fundos a que se refere o art. $1^{\circ}$ podem ser instituídos e administrados por instituições financeiras ou por sociedades seguradoras autorizadas a funcionar pela Superintendência de Seguros Privados - SUSEP.

O que se pretende ilustrar com a referência a este plano, em linhas gerais, menos pela sua relevância no mercado securitário brasileiro e mais pela sua estruturação técnica, é que se trata de um autêntico "produto financeiro", com finalidade previdenciária, tal qual um plano do tipo PGBL ou VGBL, mas em nada se confunde, a não ser pela finalidade de proteção contra eventuais necessidades econômicas, com um seguro ${ }^{145}$.

\footnotetext{
${ }^{142}$ Dedução de até $12 \%$ dos valores aportados da renda bruta anual, indicado somente para pessoas que declaram o imposto de renda no formulário completo e são vinculadas ao RGPS ou ao RPPS. A tributação incide sobre o valor total do resgate, acrescido da rentabilidade obtida durante o período do investimento, se houver.

${ }^{143}$ V.g. Vitalícia, por prazo mínimo garantido, reversível ao beneficiário etc.

${ }^{144}$ Vide item 3.8.6.1.

${ }^{145}$ Por lhe faltarem elementos essenciais à caracterização de um contrato de seguro, os quais serão expostos no Capítulo III.
} 


\section{CAPÍTULO II - BANCASSURANCE}

\section{1- Preliminarmente}

Feitas as considerações gerais sobre a previdência privada, e antes de partir para a análise do contrato de seguro, dedicaremos este capítulo em especial para tratar de um fenômeno que vem despontando, principalmente nas últimas décadas, como uma tendência do mercado de previdência privada e securitário.

A percepção do bancassurance e das suas consequências para o Direito do seguro e da previdência privada tem sido objeto de diversos estudos nos países da Europa Ocidental $^{146}$, mas encontramos quase nenhum no Brasil.

Os planos de previdência privada, os produtos do mercado securitário e outros instrumentos financeiros estão cada vez mais próximos. Tem sido uma tarefa bastante complexa estabelecer os contornos entre cada um, de onde eles se originam e suas diferentes implicações, inclusive do ponto de vista jurídico.

Se os planos de previdência privada fossem evidentemente e indubitavelmente reconhecidos como seguros de pessoas, desnecessária se demonstraria esta dissertação, uma vez que seria automática a aplicação das normas e princípios de seguros aos contratos previdenciários privados.

Os seguros e previdência privada demonstraram-se importantes para os bancos porque ajudam a complementar a carteira de produtos financeiros, mas, sobretudo, auxiliam na fidelização dos seus clientes, uma vez que são veículos orientados para o longo prazo.

\footnotetext{
146 V.g. SILVA, João Calvão da. Banca Bolsa e Seguros. Coimbra: Almedina, 2007; GRIFFI, Antonio Patroni e RICOLFI, Marco. Banche ed assicurazioni fra cooperazione e concorrenza. Milão: Giuffré, 1997. CASTELlano Gaetano. I Prodotti Finanziari Bancari ed Assicurativi in Quaderni di Giurisprudenza Commerciale. Milão: Giuffré, 2008. LLORENS, Luís Latorre. Los límites entre la banca y el seguro en la comunidad económica europea. In Previsión y seguro. Madrid. nº 3, enero-febrero, 1990.
} 
Ademais, as seguradoras encontraram, na conjugação de seus produtos com os de natureza financeira, um novo "nicho" de negócio ${ }^{147}$ :

Para além da vocação tradicional de cobertura de riscos específicos de seguros, as empresas de seguros têm-se assumido cada vez mais, ao longo dos últimos anos, como instituições financeiras especializadas na captação de poupança. Esta "nova função" tem sido impulsionada pela inovação financeira e pela consequente competição entre as empresas de seguros, bem como pelas sinergias intragrupo estrategicamente aproveitadas.

Por conta disso, os produtos oferecidos passaram a ser facilmente confundidos pelos consumidores $^{148}$, por aqueles que os comercializam ${ }^{149}$ e própria jurisprudência ${ }^{150}$. É essa uma das razões pelas quais este trabalho se justifica. Como classificar os planos de previdência privada comercializados nos dias de hoje? Quais regras devem a eles ser aplicadas? Sobre esse prisma do bancassurance é que se desenrolarão os próximos tópicos deste capítulo.

${ }^{147}$ A importância dos unit linked no ramo vida. (Instituto de Seguros de Portugal. Conselho Directivo, 2003 Disponível em 〈http://www.isp.pt/winlib/cgi/winlib.exe?skey=\&pesq=2\&doc=13818>, acesso em 10/04/13, p. 167)

${ }^{148}$ Sobre este tema, é bastante ilustrativo o acórdão do TJ-PA que trata da contratação de um plano de previdência privada por "engano", por um participante que pensou estar alocando seus recursos em um fundo de investimento comum: "O gerente lhe ofertou o plano PGBL como sendo o que haviam simulado na ocasião da primeira visita e o Recorrente, por não entender de investimentos financeiros e confiar no gerente por conhecê-lo há mais de 20 (vinte) anos, como reiterado depoimento do mesmo às fls. 80 , assinou a proposta e o contrato, sem, no entanto, receber sua via do instrumento que, conforme lhe fora alegado, iria ser assinada pelo diretor de área e depois remetida, o que de fato NUNCA ocorreu; em verdade, transcorrido os dois meses, não pôde retirar o valor investido em PGBL, que por se tratar de um plano de previdência privada possui período de carência de 06 (seis) meses, além de sofrer incidência do Imposto de Renda sobre o total do aplicado, e não sobre a rentabilidade no período, ou seja, COMPLETAMENTE DIVERGENTE do que havia sido explanado anteriormente). (TJ-PA - Apelação Cível : AC 200730079777 PA 2007300-79777) ${ }_{149}$ A Promotoria de Justiça do Consumidor (Ministério Público do Estado de São Paulo) instaurou o Procedimento ${ }^{\circ}$ 486/2002, convertido em Ação Civil Pública (Processo no 000.04.007046-8, $16^{\text {a }}$ Vara Cível do Foro Central de São Paulo) no qual constatou que "Unibanco AIG Previdência S.A. oferece aos consumidores um contrato de seguro de vida, que denomina Pensão ao Menor, disfarçado de contrato de previdência. Trata-se de contrato que, embora possua as mesmas características de um seguro de vida, vem apresentado sob a roupagem de um contrato de previdência. Os consumidores, sem ser devidamente informados de que se trata de contrato de seguro, podem ser levados a crer que as parcelas pagas são resgatáveis, como ocorre em diversos planos de previdência."

150 "CUMPRIMENTO DE SENTENÇA - Penhora sobre investimento financeiro sob a modalidade de fundo de previdência privada - Penhorabilidade dos valores investidos em fundo de previdência privada, por não se enquadrarem como 'pecúlio', abrangido na excludente prevista no art. 649, IV, do CPC - Produto financeiro de longo prazo previsto no art. 202 da Constituição Federal, com redação dada pela Emenda Constitucional $\mathrm{n}^{\circ} 20$, o termo 'pecúlio' abarca investimentos financeiros, com qualquer rótulo, ainda que visem resguardar o devedor de incertezas econômicas futuras - Recurso improvido." (n.g.) (TJ-SP, Agravo de Instrumento $\mathrm{n}^{\circ}$ 566.585.4/1-00) Em nosso entendimento, o equívoco está no fato de o magistrado ter entendido o pecúlio, uma cobertura de risco de natureza securitária, com estrutura específica baseada no mutualismo, como um investimento financeiro. 


\section{2- $\quad$ Conceito de bancassurance e breve histórico}

O bancassurance pode ser definido como "uma estratégia adotada por bancos e seguradoras com o objetivo de operar no mercado financeiro de forma mais ou menos integrada." 151

Para o jurista português João Calvão da Silva ${ }^{152}$, é a:

[...] ligação e colaboração entre bancos e companhias de seguros para desenvolver sinergias e economias de sistema, já sentidas, ictu oculi, na produção-comercialização de "produtos" concorrentes (seguros de vida, que vencem juros e capitalizam, e depósitos a prazo), "produtos complementares" (seguros de vida para garantia de empréstimos bancários, incluindo o crédito bancário concedido para financiar o prêmio único do contrato de seguro de vida, cartões de crédito e débito com seguros vários associados, designadamente, seguro de viagem, seguro de doença, seguro de vida, seguro de responsabilidade civil, seguro de protecção jurídica) ou mesmo "produtos" diversificados (v.g. Seguros não vida ou seguros de danos).

Como decorrência da globalização, da intensa concorrência nos mercados, da desregulamentação de alguns setores e do avanço tecnológico, as empresas têm sido forçadas a aprimorar continuamente o desempenho dos produtos que oferecem, aumentando a variedade, melhorando o atendimento e diminuindo os custos.

Uma das alternativas encontradas foi o estabelecimento de alianças estratégicas (v.g. parcerias acionárias, franquias, joint ventures etc.), nas quais cooperam em nome de suas necessidades mútuas e compartilham riscos em busca de um objetivo comum ${ }^{153}$. Trata-se de uma consequência natural do desenvolvimento social, tecnológico e econômico, próprio das últimas décadas.

151 Conforme Clarence Wong; Mike Barnshaw; Lucia Bevere. Bancaseguros: tendencias emergentes, oportunidades e retos. Relatório Sigma n. 5/07, p. 5. Disponível em: $<$ http://media.swissre.com/documents/sigma5_2007_es.pdf>. Acesso em: 11/06/12.

152 Op. cit, p. 22.

${ }^{153}$ Neste sentido, ver PAGNUSSATT, Vinicius. Alianças estratégicas de bancos com seguradoras no Brasil: análise de cinco casos, dissertação de mestrado, programa de Pós Graduação em Administração da Universidade Federal do Rio Grande do Sul, Porto Alegre, 2010. Disponível em: <http://www.lume.ufrgs.br/bitstream/handle/10183/26498/000759470.pdf?sequence=1>. Acesso em $15 / 06 / 12$. 
Neste cenário, destacam-se as uniões entre os setores de seguros, previdência privada e bancos, primeiramente desenvolvidas nos países europeus, em especial na França, Portugal, Espanha e Itália, e ganharam força a partir de meados da década de 90, espalhando-se também para outros países.

Os bancos, explica Vinicius Pagnussatt ${ }^{154}$, "vislumbraram nos produtos de seguros uma solução para a diversificação e para a ampliação de seus negócios, dando origem ao conceito de bancassurance." (grifo do autor)

As seguradoras, por sua vez, viram nos bancos um canal de distribuição de maior “capilaridade" e penetração no mercado do que os meios tradicionalmente utilizados (corretores de seguros e agentes) ${ }^{155}$.

E esse sistema traz ainda vantagens aos clientes, pois, como destaca Vincenzo Donativi ${ }^{156}$, a sinergia entre bancos e seguradoras:

[...] possibilita uma maior divulgação das informações e operações securitárias, exigência seguramente muito menos satisfeita em um sistema de distribuição limitado à estrutura mais rígida das agências; o serviço "global" oferecido pela rede bancária lhes permite otimizar as escolhas de investimento e diversificação da carteira, utilizando um único intermediário, incluindo também informações sobre produtos previdenciários ou, como acontece com mais frequência, produtos de conteúdo misto (de previdência privada e financeiros). (tradução livre)

A comprovação da grandeza do bancassurance, especialmente no ramo vida, pode ser comprovada pelo gráfico a seguir ${ }^{157}$ :

\footnotetext{
${ }^{154}$ Op. Cit, p. 10.

${ }^{155}$ Como afirma Vincenzo Donativi: (Tradução livre) Quanto às companhias de seguros, o interesse de utilizar o canal bancário está ligado à necessidade de uma rede de distribuição de mais "capilaridade" do que a rede tradicional ligada às agências, a fim de prosseguir uma penetração mais eficaz do mercado. "Quanto alle imprese di assicurazione, l'interesse ad avvalersi del canale bancario si recollega alla necessità di utilizzare una rete distributiva più "capillare" di quella tradizionalmente cllegata alle agenzie, in modo da poter perseguire un più efficace grado di penetrazione del mercato." (La distribuzione bancaria di prodotti assucurativi, in Banche ed Assicurazioni fra cooperazione e concorrenza. Milão: Giuffrè, 1997, p. 57)

156 "Dal canto loro, gli utenti si trovano a beneficiare della sinergia distributiva banche-assicurazioni per diversi profili. Innanzitutto in quanto ciò rende possible una più ampia divulgazione delle informazioni sull'existenza ed il funzionamento del prodotto assicurativo, esigenza sicuramente meno soddisfatta in un sistema distributivo limitato alla più rigida struttura per agenzie quindi perché il servizio "globale" offerto dalla banca consente loro di ottimizzare, mediante il riscorso ad un unico intermediario, la scelte di investimento e di diversificazione del portafoglio, in esso includendo anche rapporti a contenuto previdenziale, o, come più spesso accade, a contenuto misto (previdenziale-finanziario)". (Op. cit, p. 58)
} 
Gráfico 2 - Cota de distribuição de bancasseguros nos mercados selecionados

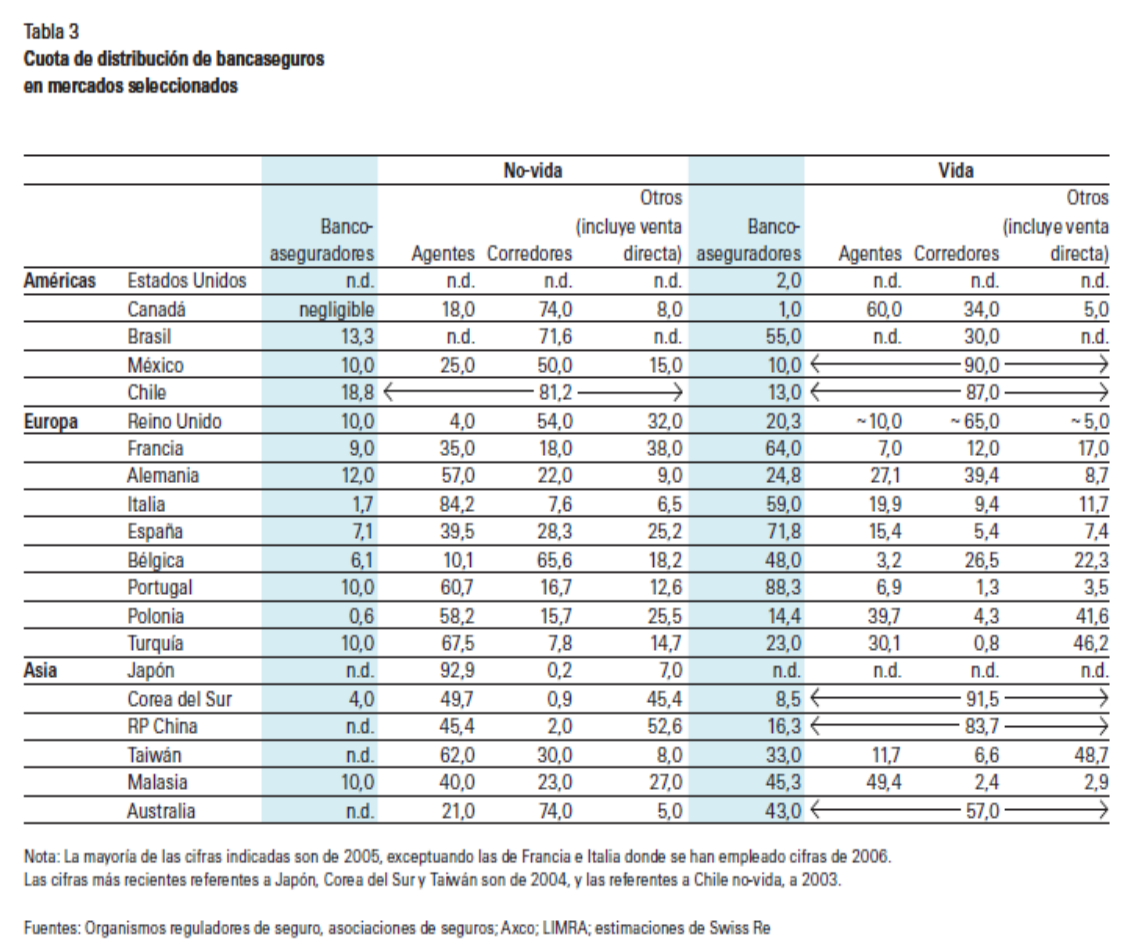

\section{3- $\quad$ Atividade financeira}

Segundo a classificação adotada por João Calvão da Silva ${ }^{158}$, a atividade financeira subdivide-se em três partes: crédito, investimento e seguro.

A atividade de crédito é aquela reservada aos bancos, intermediários financeiros que recolhem poupanças (disponibilidades monetárias) de agentes superavitários, sob a forma de depósitos ou outros fundos, e transferem-nas a outros (agentes deficitários) por meio de empréstimos ou outras formas de financiamento e concessão de credito.

É regulamentada em nosso país pela lei $\mathrm{n}^{\circ}$ 4595/64, que define instituições financeiras no art. 17:

157 WONG, Clarence; BARNSHAW, Mike; BEVERE, Lucia. Bancaseguros: tendencias emergentes, oportunidades e retos. Op. cit, p. 5 ..

${ }^{158}$ Op. cit. p. 18 e ss. 
Consideram-se instituições financeiras, para os efeitos da legislação em vigor, as pessoas jurídicas públicas ou privadas, que tenham como atividade principal ou acessória a coleta, intermediação ou aplicação de recursos financeiros próprios ou de terceiros, em moeda nacional ou estrangeira, e a custódia de valor de propriedade de terceiros. Parágrafo único. Para os efeitos desta lei e da legislação em vigor, equiparam-se às instituições financeiras as pessoas físicas que exerçam qualquer das atividades referidas neste artigo, de forma permanente ou eventual.

A segunda parte (investimento) corresponde aos valores mobiliários e outros instrumentos financeiros, negociados no mercado de capitais e seu segmento - mercado de valores mobiliários, cuja regulamentação no Brasil é feita pela lei nº6385/76.

Por fim, a terceira parte corresponde ao mercado de seguros, definida por João Calvão da Silva ${ }^{159}$ como "aplicação de poupanças em pagamentos de prêmios de seguros, para fazer frente a necessidades futuras".

No Brasil, o mercado de seguros é regulamentado pelo DL $\mathrm{n}^{\mathrm{o}} 73 / 66$, e a previdência privada, que no caso das entidades abertas também integra o Sistema Nacional de Seguros Privados é regida pela LC 109/01.

Calvão explica que a tendência mundial é de integração progressiva entre essas três partes da atividade financeira, a qual se verifica pela prestação de serviços de investimento pelos bancos, pela multiplicação dos intermediários financeiros e pela comercialização de seguros pelos bancos.

Assim retrata Luís Latorre Llorens ${ }^{160}$ :

${ }^{159}$ Op. cit, p. 20.

160 "En efecto, el proceso de aproximación, o incluso de "confusión" (también llamado en otros idiomas "décloissonement" o "dessegregation") entre el seguro y la banca es cada vez más evidente, y preocupa no sólo a las autoridades nacionales sino también a las comunitarias de Bruselas. En España hemos vivido recientemente una de sus manifestaciones, con el fenómeno de las operaciones que han dado en llamarse "seguros a prima única"; el carácter patológico de nuestra experiencia no permite inferir que el mencionado proceso de aproximación o confusión sea esencialmente anormal. Es más, puede considerarse natural consecuencia del desarrollo social, tecnológico y económico propio de estas dos últimas décadas del siglo. Las fronteras entre los diversos servicios financieros tienden a hacerse cada vez más tenues y ello puede apreciarse desde varios puntos de vista. En primer lugar, desde La perspectiva de los productos; algunos de ellos son difíciles de encuadrar con claridad. Cabe citar aquí, como ejemplo, desde el seguro de vida universal, hasta las conocidas operaciones a prima única. En segundo término, desde el ángulo de la comercialización de los productos se observa también una tendencia hacia la andadura común. Y como tercer caso, tenemos la proliferación de los llamados conglomerados financieros, pluralidad de empresas del mismo 
Na verdade, o processo de aproximação, ou mesmo "confusão" (também chamado em outras línguas "décloissonement" ou "dessegregation") entre seguros e bancos é cada vez mais evidente, e preocupa não só as autoridades nacionais, mas também a comunidade de Bruxelas. Na Espanha, temos experimentado recentemente uma de suas manifestações, com o fenômeno das operações que foram chamadas "seguros a prêmio único"; o caráter patológico da nossa experiência não nos permite inferir que o mencionado processo de aproximação ou confusão seja essencialmente anormal. Além disso, pode-se ser considerar uma consequência natural destas últimas duas décadas do século. As fronteiras entre os vários serviços financeiros tendem a tornarem-se cada vez mais tênues, e isto pode ser visto a partir de diversos pontos de vista. Primeiro, do ponto de vista dos produtos; alguns deles são difíceis de serem enquadrados com clareza. Cabe citar, como exemplo, desde o seguro de vida universal, até as operações de prêmio único. Em segundo lugar, do ponto de vista da comercialização dos produtos observa-se também uma tendência para a jornada comum. E em terceiro lugar, temos a proliferação dos chamados conglomerados financeiros, pluralidade de empresas do mesmo grupo que, agindo como diferentes faces do mesmo, atuar em outras tantas facetas do mercado de serviços financeiros. (Tradução livre) (n.g.)

A doutrina italiana, em especial Marco Rocolfi ${ }^{161}$, também retrata essa evolução da atividade financeira, que culminou na convergência dos três setores - crédito, investimento e seguros:

Como já foi dito, uma e outra atividade floresceram, o que teria sido impensável para o jurista dos anos 50. E, se olharmos bem, percebemos imediatamente que a direção da viagem entre uma e outra categoria de operadores é, em qualquer caso, no sentido de convergência. A prática atual e a evolução legislativa de fato aproximou os bancos das seguradoras. (Tradução livre)

\section{4- "Produtos" ou "serviços financeiros"}

grupo que, actuando como caras distintas del mismo, actúan en otras tantas facetas del mercado de servicios financieros". (Op. cit. p. 84)

161 Secondo quanto si è detto, l'una el'altra attività hanno conosciuto sviluppi che sarebbero apparsi impensabili as giurista degli anni Conquanta. E, se ben guardiamo, ci avvediamo subito che la direzione di marcia fra l'una e l'altra categoria di operatori è in ogni caso avvenuta nel segno della convergenza. La pratica corrente e l'evoluzione legislativa hanno infatti avvicinato banche ed assicuratori. Assicurazione, credito e investimento. In Banche Ed assucurazioni fra cooperazione e concorrenza. Milão: Giuffrè, 1997, p. 8 . 
Na nomenclatura europeia costuma-se falar em serviços financeiros para designar as prestações ou atividades bancárias, de bolsa de valores e de atividades seguradoras, como coloca João Calvão da Silva ${ }^{162}$ :

Comummente, na Europa como nas instâncias internacionais, fala-se de serviços financeiros para designar as prestações ou actividades bancárias, as prestações ou actividades bolsistas e as prestações ou actividades seguradoras, sendo evidente a sinédoque nas duas primeiras, com o emprego da parte pelo todo: de Banca, por instituições de crédito/sociedades financeiras; de Bolsa, por mercados de valores mobiliários (mercados de capitais, mercados financeiros ou mercados dos instrumentos financeiros) e intermediários financeiros ou empresas de investimento. (grifos do autor)

O autor português ${ }^{163}$ salienta que é comum a adoção do termo "produtos financeiros" (em uma linguagem mais econômica do que jurídica) para se referir a valores mobiliários e outros instrumentos financeiros passíveis de objetos de relações jurídicas firmadas no mercado bancário, de capitais e de seguros, com o objetivo de fazer investimentos financeiros e gerir os riscos inerentes às operações ${ }^{164}$.

Contudo, percebe-se na Europa uma dificuldade na delimitação de tais produtos, sendo que uma mesma operação pode ser considerada como bancária em um país, e como securitária no outro, como retrata Latorre Llorens ${ }^{165}$ :

${ }^{162}$ Banca Bolsa e Seguros. Coimbra: Almedina, 2007, p. 17.

163 Idem, ibidem.

${ }^{164}$ No mesmo sentido afirma Renzo Costi (I prodotti finanziari, bancari ed assicurativi in I prodotti finanziari, bancari ed assicurativi - in ricordo di Gaetano Castellano. Milão: Giuffré, 2008, p. 24), para quem todos os produtos securitários são financeiros, sendo os primeiros uma espécie dos segundos.

${ }_{165}$ Por una parte, la falta de reglas precisas que permitan resolver las cuestiones que en este orden vayan planteándose. La Ley no suele dar definiciones ni establecer fronteras, siendo el criterio de las autoridades de control, y en última instancia el de los tribunales, el decisivo en la materia. Sólo son frecuentes las condiciones legales para calificar a ciertas modalidades del seguro de vida como aptas para generar beneficios fiscales en el impuesto sobre la renta de las personas físicas (al igual que sucede en nuestra ley de dicho impuesto, que exige cierta duración y la cobertura de ciertos riesgos, etcétera). Pero no hay, insisto, definiciones legales del seguro de vida. La República Federal de Alemania prohíbe a las entidades aseguradoras las operaciones de capitalización, por considerar que son propias de la banca, y no implicar riesgo alguno. Es, quizá, el único caso claro, aunque limitado. Por otra parte, se aprecia una amplia variedad en los criterios vigentes en los distintos países. Más adelante haremos una referencia a esta gama, que planteará problemas importantes cuando se implante la libertad de prestación de servicios en la Comunidad. Cierta operación, considerada como bancaria en el Estado A, podrá quizá ser ofrecida en él desde el Estado B, que la califica como operación de seguro. Esta situación perjudicará a los aseguradores establecidos en A, que se verán negativamente discriminados con respecto a los de B. Una solución posible se basa en la distinción entre prestación activa y pasiva, que introduce el proyecto de directiva sobre libre prestación de servicios en seguros de vida. De esta forma, un residente en A podría tomar la iniciativa de concertar la operación prohibida en dicho Estado, con un asegurador de B; pero a éste estaría vetado buscar clientes en A, para la operación en cuestión. Soluciones como ésta, o análogas, serán necesarias mientras la libertad de 
Por um lado, a falta de regras precisas para resolver as questões que nesta ordem estão surgindo. A Lei não costuma dar definições ou estabelecer limites, ficando a critério das autoridades de controle e, finalmente, dos tribunais, a questão decisiva sobre a matéria. Apenas são frequentes as condições legais para qualificar para certas modalidades de seguro de vida como aptas para gerar benefícios fiscais no imposto de renda das pessoas físicas (como é o caso em nossa legislação desse imposto, que exige certa duração e a cobertura de determinados riscos etc.) Mas não há, insisto, definições legais sobre o seguro de vida. A República Federal da Alemanha proíbe às seguradoras as operações de capitalização, por considerar que são próprias dos bancos, e não implicarem risco algum. É talvez o único caso claro, ainda que limitado. Por outro lado, existe uma ampla variedade nos critérios vigentes nos mais variados países. Mais adiante, faremos uma referência a esta variedade, que trará graves problemas quando se implantar a liberdade de prestação de serviços na Comunidade Europeia. Determinada operação, considerada como bancária no Estado A, poderá talvez ser oferecida a partir do estado B, que a qualifica como uma operação de seguro. Esta situação prejudicará os seguradores estabelecidos em A, que serão severamente discriminados em relação aos de B. Uma possível solução baseia-se na distinção entre prestação ativa e passiva, que introduz o projeto de diretiva sobre livre prestação de serviços em seguro de vida. Assim, um residente de A poderia tomar a iniciativa realizar a transação proibida naquele Estado com um segurador de B, mas a este estaria vetado buscar clientes em A para a operação em questão. Soluções como esta, ou similares, serão necessárias enquanto a liberdade de prestação de serviços tiver de coexistir com a falta de harmonização legislativa a nível comunitário nesta matéria. (Tradução livre) (n.g.)

Ou seja, pelo fato de as atividades de seguros, mercado de capitais e bancário estarem cada vez mais próximas, os clientes, os vendedores dos produtos e a própria jurisprudência muitas vezes acabam por confundir tais conceitos ${ }^{166}$.

João Calvão da Silva ${ }^{167}$, assim, conclui:

[...] sob este ângulo de investimentos financeiros e apólices variáveis / híbridas ("assurfinance"), a visão clássica das seguradoras como empresas que prestam um serviço (de neutralização de riscos) por um preço (prêmio) é superada, melhor, enriquecida pela coeva consideração das mesmas ainda como instituições financeiras que também recolhem do público fundos e os transferem para agentes económicos deficitários, à semelhança de outros investidores institucionais.

prestación de servicios haya de coexistir con una falta de armonización legislativa a nivel comunitario en esta materia. (Op. cit., p. 84)

${ }^{166}$ Como retratado anteriormente.

${ }^{167}$ Op. cit., p. 25. 
Logo, verifica-se que, de diversas formas, os bancos, as seguradoras e os administradores dos fundos de investimento estão interpenetrados, interligados ou integrados, oferecendo todos os três alternativas de investimentos.

Os três possuem sinergias ou vantagens competitivas e apresentam serviços financeiros entrelaçados, sujeitos ao mesmo controle pelo grupo econômico.

Não significa, contudo, ter ocorrido dissolução ou desaparecimento total das fronteiras entre tais setores, pois cada qual tem a sua função essencial, o seu ramo de atividade. Como salienta Pedro Jesus Baena Baena ${ }^{168}$ é muito diferente o alicerce em que se assenta o contrato de seguro daquele do depósito bancário, já que o contrato de seguro é constituído em uma base atuarial, o que não ocorre no outro.

Entretanto, percebe-se que tanto o canal bancário quanto o das seguradoras acabam por ter, em certa medida, finalidades semelhantes das entidades de previdência privada, no sentido de ambos oferecerem instrumentos que permitem a acumulação de recursos com visão de longo prazo, muito embora cada qual com as suas particularidades.

Em linhas gerais, os planos previdenciários abertos devem ser contratados em entidades de previdência privada ou seguradoras autorizadas a operar no ramo vida, podendo ser utilizados como poupança de longo prazo, mas possibilitando a contratação de uma renda ao longo do término do período de diferimento. No caso de haver uma aquisição de renda vitalícia, por exemplo, esse contrato adquire contornos de um seguro.

Ou seja, a complexidade do assunto escolhido para este tema decorre do fato de estarmos tratando de produtos que possuem algumas características de seguro, mas nos quais o risco corre por conta do próprio "segurado" (o participante do plano de previdência), o que representaria uma contradição com o conceito clássico de seguro ${ }^{169}$, e o aproximaria do resto dos produtos financeiros.

\footnotetext{
168 Op. cit., p. 19.

169 No sentido da pulverização de riscos e transferência das consequências danosas de um evento para a seguradora.
} 
Tapia Hermida ${ }^{170}$ explica que os tribunais cíveis espanhóis têm sido frequentemente submetidos ao exame de algumas operações financeiras para determinar se estão diante de contratos de seguro, com o consequente direito do benefício à indenização, ou se estão diante de contratos de capitalização, nos quais, ao invés de aplicar preceitos de direito do seguro, a seguradora deveria reger-se por normas de direito securitário.

Especificamente, uma operação financeira que consiste no pagamento pelo contratante de um desembolso único em troca do compromisso da seguradora em pagar uma prestação determinada quanto à duração e ao valor, é qualificada como um contrato de capitalização, cuja causa não é a cobertura de um risco, mas a formação de um capital em que, mesmo quando se utiliza a técnica atuarial, tem pouca importância econômica o fato do segurado sobreviver ou morrer, já que a única coisa que muda é a pessoa a quem se deverá pagar o capital segurado. Os tribunais administrativos, depois de rejeitar uma série de elementos não determinantes para a qualificação de um contrato como seguro de vida (tais como a sua denominação como "operação financeira", a busca de um tratamento fiscal, a duração da operação etc.) têm centrado sua análise sobre a causa do contrato de seguro de vida que - com base em uma interpretação sistemática dos artigos 1 e 83 da LCS - consiste na transferência do risco, falta uma verdadeira existência de cobertura pela seguradora e de aleatoriedade no contrato e, portanto, não se pode qualificar o mesmo como seguro de vida por falta de causa. Acrescentase que para determinar em cada caso se há essa transferência de risco, é fundamental a aplicação da técnica atuarial, no sentido de combinar os elementos biométricos (tábuas de mortalidade) e financeiros (tipos de juros), de tal modo que se o contrato examinado somente se tem em conta a aplicação de critérios financeiros, não estaremos diante de um seguro de vida, mas sim de uma operação de poupança ou investimento. (Tradução livre)

O autor espanhol continua ${ }^{171}$ :

170 "En concreto, una operación financiera consistente en el pago por el contratante de un desembolso único a
cambio del compromiso de la aseguradora de pago de una prestación determinada en cuanto a su duración y
importe, se ha calificado como un contrato de capitalización cuya causa no es la cobertura de un riesgo, sino
la formación de un capital en el que, aun cuando se utiliza la técnica actuarial, tiene escasa trascendencia
económica que el asegurado sobreviva o fallezca, ya que lo único que varía es la persona a la que habrá que
restituir la soma asegurada. Los tribunales contencioso-administrativos, tras descartar una serie de elementos
no determinantes para la calificación de un contrato como seguro de vida (tales como su denominación de
'operación financiera', la búsqueda de un tratamiento fiscal, la duración de la operación, etc), han centrado su
análisis en la causa del contrato del seguro de vida que - sobre la base de una interpretación sistemática de
los artículos 1 y 83 de la LCS - consiste en el desplazamiento, falta una verdadera existencia de cobertura por
la entidad aseguradora y de aleatoriedad en el contrato y, por lo tanto, no puede calificarse el mismo como
seguro de vida por falta de causa. Se añade que para determinar en cada caso si se há producido tal
desplazamiento de riesgo, es de importancia decisiva la aplicación de la técnica actuarial, en el sentido de
combinar los elementos biométricos (tablas de mortalidad) y financieros (tipos de interés técnico), de modo
tal que si en el contrato examinado solo se tiene en cuenta la aplicación de criterios financieros, no nos
encontraremos ante un seguro de vida sino ante una operación de ahorro. (SSAN 14-1-1997, 3-10-1997 y 27-
9-2001)." (Manual, Op. cit., p. 249)
171 "La litigiosidad asociada a estos seguros obedece tanto a su estructura jurídica compleja como a su
característica definitoria de que el riesgo de la inversión corre a cargo del tomador, lo que parece contradecir 
A litigiosidade associada a estes seguros deve-se tanto à sua estrutura jurídica complexa quanto à sua característica marcante de que o risco do investimento é suportado pelo tomador de seguro, o que parece contradizer a idéia tradicional de transferência de risco para a seguradora e os aproxima do resto dos produtos de investimento financeiro presentes no mercado. Esta característica essencial deste tipo de seguro de vida faz com que seja vital garantir que o tomador do seguro ou segurado tenha plena consciência do risco assumido, de modo que os tribunais têm dado especial importância à publicidade ou a documentação informativa que a instituição financeira que os comercializa oferece aos seus segurados (SAS Navarra 1997/07/04 [AC 1997,1612$]$ ). Diante da jurisprudência que teve oportunidade de se pronunciar sobre este tipo de seguro, podemos distinguir dois cenários de contratos complexos nas circunstâncias de cada caso: em primeiro lugar, os casos de em que, pela análise da documentação contratual, percebe-se que o objetivo principal do produto financeiro é a celebração de um contrato de seguro de vida e de investimento, e que as disposições de seus fundos de investimento têm caráter secundário. De outro lado, Por parte outra , onde o principal é o aporte de capitais, tendo o seguro de vida um caráter auxiliar (resultando, muitas vezes, quase em uma "gratuidade" (SAP Zaragoza 05/07/2001 [JUR 2001150777 ]).

Ou seja, no atual contexto, em que bancos e seguradoras atuam em cooperação na distribuição de seguros e planos de previdência privada, verificou-se também a criação de novos produtos financeiros como, por exemplo, os seguros de vida resgatáveis ${ }^{172}$, os seguros de vida a prêmio único e outros "seguros" em que a causa é a formação de um capital, e não a cobertura de um risco atuarial, que era a função para a qual as seguradoras originalmente haviam sido concebidas.

Constata-se, portanto, uma ampliação nas atividades das seguradoras e entidades de previdência privada, que passaram a ofertar produtos de investimento, em que inexiste o

la idea tradicional del traspaso del riesgo al asegurador y les aproxima al resto de productos financieros de inversión presentes en el mercado. Dicha característica esencial de este tipo de seguros de vida hace que resulte de vital importancia garantizar que el tomador o asegurado es plenamente consciente del riesgo que asume, por lo que los tribunales vienen concediendo una especial relevancia a la documentación informativa o publicitaria que la entidad financiera que los comercializa entrega a sus tomadores (SAS Navarra 4-7-1997 [AC 1997, 1612]). A la vista de la jurisprudencia que ha tenido ocasión de pronunciarse sobre este tipo de seguros, podemos distinguir dos hipótesis de contratos complejos según las circunstancias de cada caso: por una parte, aquellos casos en los que, del análisis de la documentación contractual, se deduce que la finalidad principal del producto financiero es la celebración de un contrato de seguro de vida y que la inversión de sus provisiones en fondos de inversión tiene un carácter secundario. Por otra parte, los casos en que lo principal es la suscripción de participaciones, teniendo el seguro de vida un carácter accesorio (que se traduce, a menudo, en su 'gratuidad') (SAP Zaragoza 7-5-2001 - [JUR 2001, 150777]).” (Manual, Op. cit., p. 260)

${ }^{172}$ V.g. Unit linked. 
risco atuarial ou em que o risco atuarial é secundário ${ }^{173}$, e também nas atividades das instituições financeiras, que passam a oferecem produtos de natureza previdenciária ${ }^{174}$.

\section{5- Bancassurance no Brasil}

No Brasil, a história do bancassurance iniciou em 1966, com a publicação da Circular do Banco Central do Brasil n 54, que permitiu aos bancos realizar a cobrança bancária das operações de seguros. Verificou-se que a arrecadação dos prêmios poderia ser uma interessante forma de captação de recursos, pois as instituições financeiras recebiam o valor dos prêmios antecipadamente, e o pagamento das indenizações era posterior, sem atualização monetária na época. Isso lhes permitia obter rentabilidade com a aplicação de tais recursos.

Alexis Cavicchini ${ }^{175}$ afirma que "a imagem do negócio de seguros, no final da década de setenta, estava tão ligada aos bancos que os clientes muitas vezes não sabiam, nas agências, separar a atividade do banco com a da seguradora."

Em 1988, o setor de seguros passou a integrar o Sistema Financeiro Nacional, evidenciando o movimento de convergência entre os setores.

Atualmente, o que se vê é uma imagem cada vez mais interligada entre os setores de banco, seguros e previdência privada, todos esses entendidos como atividades financeiras. As maiores seguradoras brasileiras utilizam-se do canal bancário para a comercialização de seus produtos, como se pode depreender dos dados da tabela a seguir $^{176}$ :

\section{Gráfico 3 - Ranking de seguros - total sem VGBL}

\footnotetext{
${ }^{173}$ Como ocorre no Brasil com o PGBL e o VGBL, por exemplo.

${ }^{174}$ V.g. FAPI.

${ }^{175}$ A história dos seguros no Brasil: 1808, 2008. Rio de Janeiro: Cop. Editora, 2008.

${ }^{176}$ Ranking das seguradoras, SINCOR - SP - Sindicato dos Corretores de Seguros e Resseguros do Estado de São Paulo, Ranking de seguros total (sem VGBL), p. 6. Disponível em: <http://www.ratingdeseguros.com.br/pdfs/rankbra0612.pdf>. Acesso em: 01/10/13.
} 


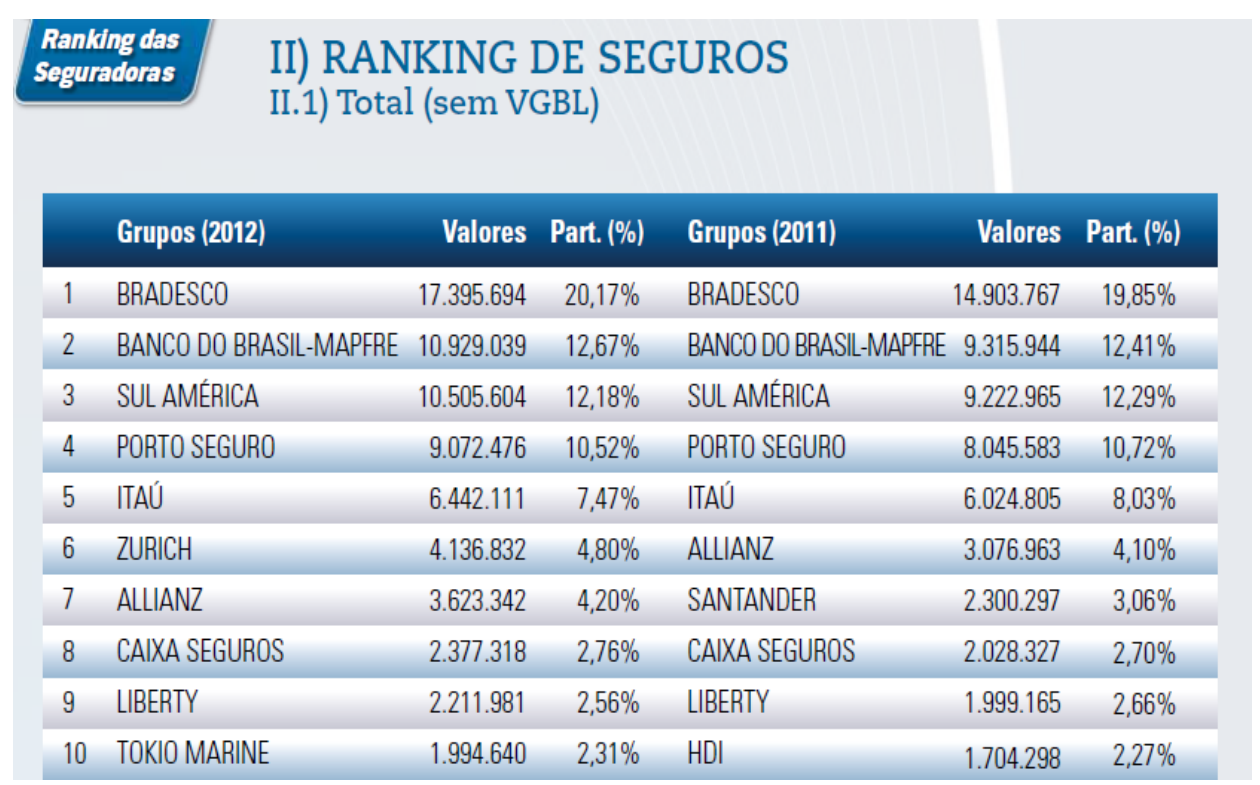

Dentre os dez maiores grupos seguradores do mercado brasileiro em 2012, cinco eram vinculados ao canal bancário (Bradesco, Banco do Brasil, Itaú, Zurich - por meio de joint venture com Santander, e Caixa).

A situação é ainda mais evidente quando se considera exclusivamente o ramo de seguro de pessoas: de dez dos maiores grupos seguradores em 2012, seis eram vinculados ao canal bancário ${ }^{177}$ :

\section{Gráfico 4 - Ranking de seguros - Pessoas (sem VGBL)}

${ }^{177}$ Ranking das seguradoras, SINCOR - SP - Sindicato dos Corretores de Seguros e Resseguros do Estado de São Paulo, Ranking de seguros de pessoas (sem VGBL), p. 12. Disponível em: <http://www.ratingdeseguros.com.br/pdfs/rankbra0612.pdf>. Acesso em: 01/10/13. 


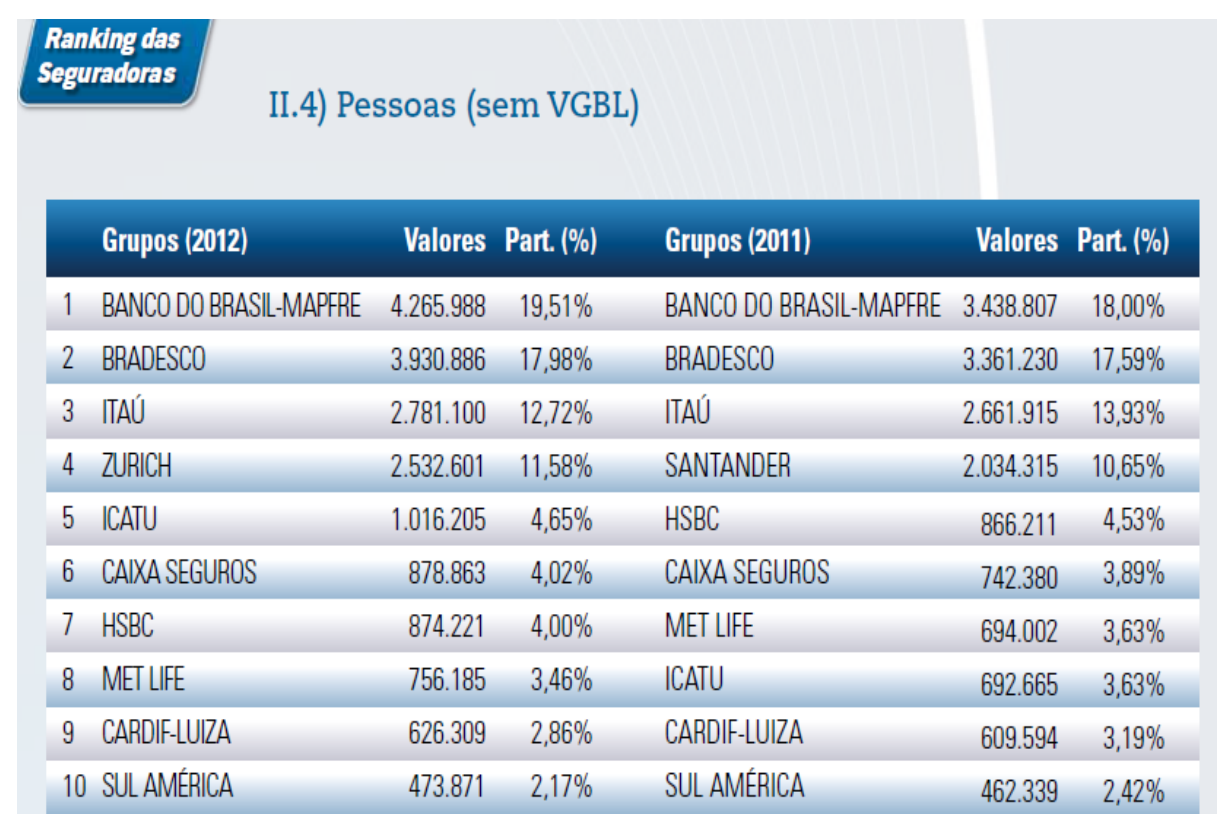

Em sede de previdência privada, o canal bancário é responsável por mais de $97 \%$ dos planos do tipo VGBL e mais de $86 \%$ dos planos PGBL, conforme as duas tabelas a seguir, respectivamente ${ }^{178}$.

\section{Gráfico 5 - Ranking de seguros -VGBL}

\begin{tabular}{lllllll}
$\begin{array}{l}\text { III) ANEXO } \\
\text { III.1) VGBL }\end{array}$ & & & & & \\
& & & & & \\
& & & & & & \\
& Grupos (2012) & Valores & Part. (\%) & Grupos (2011) & Valores & Part. (\%) \\
\hline 1 & BRADESCO & 17.596 .740 & $29,57 \%$ & BRADESCO & 14.723 .541 & $33,93 \%$ \\
\hline 2 & ITAÚ & 15.889 .912 & $26,70 \%$ & ITAÚ & 10.008 .068 & $23,07 \%$ \\
\hline 3 & BRASILPREV & 15.680 .000 & $26,35 \%$ & BRASILPREV & 9.383 .644 & $21,63 \%$ \\
\hline 4 & CAIXA SEGUROS & 3.449 .290 & $5,80 \%$ & CAIXA SEGUROS & 3.363 .010 & $7,75 \%$ \\
\hline 5 & ZURICH & 2.571 .536 & $4,32 \%$ & SANTANDER & 2.708 .256 & $6,24 \%$ \\
\hline 6 & HSBC & 2.414 .700 & $4,06 \%$ & HSBC & 1.822 .045 & $4,20 \%$ \\
\hline 7 & ICATU & 618.621 & $1,04 \%$ & SAFRA & 369.527 & $0,85 \%$ \\
\hline 8 & SAFRA & 447.296 & $0,75 \%$ & ICATU & 299.230 & $0,69 \%$ \\
\hline 9 & SUL AMÉRICA & 263.365 & $0,44 \%$ & MET LIFE & 190.538 & $0,44 \%$ \\
\hline 10 & MET LIFE & 254.901 & $0,43 \%$ & SUL AMÉRICA & 183.686 & $0,42 \%$ \\
\hline
\end{tabular}

\footnotetext{
${ }^{178}$ Ranking das seguradoras, SINCOR - SP - Sindicato dos Corretores de Seguros e Resseguros do Estado de São Paulo, VGBL, pp 18 e $20 . \quad$ Disponível em: <http://www.ratingdeseguros.com.br/pdfs/rankbra0612.pdf >. Acesso em: outubro/2013.
} 


\section{Gráfico 6 - Ranking de seguros - Previdência}

\begin{tabular}{|c|c|c|c|}
\hline \multicolumn{4}{|c|}{ III.2) Previdência } \\
\hline Grupos (2012) & Valores Part. (\%) & Grupos (2011) & Valores Part. $(\%)$ \\
\hline $1 \quad$ BRADESCO & $3.273 .277 \quad 30,63 \%$ & BRADESCO & $3.061 .343 \quad 30,55 \%$ \\
\hline 2 BRASILPREV & $2.599 .734 \quad 24,33 \%$ & BRASILPREV & $2.352 .566 \quad 23,48 \%$ \\
\hline $3 \quad$ ITAÚ & $1.962 .560 \quad 18,37 \%$ & ITAÚ & $1.794 .378 \quad 17,91 \%$ \\
\hline $4 \quad$ ZURICH & $497.234 \quad 4,65 \%$ & SANTANDER & $617.247 \quad 6,16 \%$ \\
\hline $5 \quad H S B C$ & $456.319 \quad 4,27 \%$ & $\mathrm{HSBC}$ & $418.146 \quad 4,17 \%$ \\
\hline 6 CAIXA SEGUROS & $450.662 \quad 4,22 \%$ & CAIXA SEGUROS & $415.403 \quad 4,15 \%$ \\
\hline $7 \quad$ MONGERAL & $264.994 \quad 2,48 \%$ & MONGERAL & $242.175 \quad 2,42 \%$ \\
\hline 8 CAPEMISA & $256.238 \quad 2,40 \%$ & SUL AMÉRICA & $230.223 \quad 2,30 \%$ \\
\hline $9 \quad$ ICATU & $234.382 \quad 2,19 \%$ & CAPEMISA & $228.574 \quad 2,28 \%$ \\
\hline 10 SUL AMÉRICA & $234.133 \quad 2,19 \%$ & ICATU & $200.337 \quad 2,00 \%$ \\
\hline
\end{tabular}

Logo, resta comprovada, numericamente, no Brasil, a forte convergência entre os canais bancário e de seguros e previdência privada, caracterizando, portanto, o fenômeno do bancassurance.

Ademais, a nomenclatura dos produtos também é confundida no próprio Poder Judiciário brasileiro, o qual enxerga, nos produtos previdenciários privados, autênticos investimentos:

Separação judicial Partilha consensual realizada, com exclusão apenas do plano de previdência privada. Valores depositados na constância do casamento devem observar a meação. Previdência privada está equiparada a investimento financeiro. ${ }^{179}$ (n.g.)

O saldo de depósito em PGBL - Plano Gerador de Benefício Livre não ostenta nítido caráter alimentar, constituindo aplicação financeira de longo prazo, de relevante natureza de poupança previdenciária, porém susceptível de penhora. O mesmo sucede com valores em caderneta de poupança e outros tipos de aplicações e investimentos, que, embora possam ter originalmente natureza alimentar, provindo de remuneração mensal percebida pelo titular, perdem essa característica no decorrer do

\footnotetext{
${ }^{179}$ TJ-SP, Apelação n ${ }^{\circ}$ 9168953-27.2007.8.26.0000.
} 
tempo, justamente porque não foram utilizados para manutenção do empregado e de sua família no período em que auferidos, passando a se constituírem investimento ou poupança. ${ }^{180}$ (n.g.)

ILEGITIMIDADE 'AD CAUSAM' Pessoa jurídica. Hipótese em que os consumidores acionaram o banco em vez da empresa previdenciária Admissibilidade. Aplicação da teoria da aparência Autora que mantinha relação direta com a instituição financeira adquirindo serviço através dela - Preliminar rejeitada Recurso improvido. ${ }^{181}$ (n.g.)

${ }^{180}$ STJ, Recurso Especial n ${ }^{\circ} 1.121 .719$.

${ }^{181}$ TJ-SP, Apelação no 0002205-73.2009.8.26.0038. 


\section{CAPÍTULO III - CARACTERIZAÇÃO DOS SEGUROS PRIVADOS}

\subsection{Da solidariedade à sociedade de risco}

O temor com relação aos perigos da vida acompanha o ser humano desde os primórdios da sua história. Neste sentido, Pedro Alvim ${ }^{182}$ leciona:

A eventualidade de fatos danosos aos interesses do homem sempre existiu. O risco é inerente à luta de integração dos seres vivos ao meio ambiente. A experiência de sua ocorrência acabou gerando a atitude permanente de vigilância que constitui um dos privilégios do espírito humano.

Nossos ancestrais tinham uma postura mais passiva diante do perigo, por acreditarem que os acontecimentos eram frutos de fenômenos mágicos, místicos ou religiosos. As catástrofes eram vivenciadas como flagelo ou punição dos deuses, como explica Carlos José María Facal ${ }^{183}$ :

O homem pré-histórico tinha uma mentalidade mágico-animista. Não podia explicar os fenômenos da natureza nem concebia a noção de causa e efeito. As coisas tinham uma "alma" própria, uma "mão" que lhes dava poderes, tais como dar à luz, matar e nascer. (Tradução livre)

Embora, por meio do estágio evolutivo atingido, a vida humana atualmente seja em princípio "melhor" do que no passado, por conta das conquistas no plano do desenvolvimento racional ${ }^{184}$, paradoxalmente, o homem passou a ter de lidar com outros tipos de perigos, próprios da sociedade moderna ${ }^{185}$.

\footnotetext{
${ }^{182}$ Op. cit., p. 1.

183 "El hombre prehistórico había tenido una mentalidad mágico-animista. No podía explicar los fenómenos de la naturaleza ni concebía la noción de causa y efecto. Las cosas tenían un "alma" propia, un "mana" que les daba poderes, tales como dar luz, matar, nacer." (Op cit. p. 2.)

${ }^{184}$ Especialmente com relação à ciência, tecnologia e medicina, que permitiram prolongar a longevidade humana.

${ }^{185}$ Conforme Ulrich Beck, "na modernidade desenvolvida, que surgiu para anular as limitações impostas pelo nascimento e para oferecer às pessoas uma posição na estrutura social em razão de suas próprias escolhas e esforços, emerge um novo tipo de destino "adscrito" em função do perigo, do qual nenhum esforço permite escapar." (Sociedade de risco - rumo a uma outra modernidade. São Paulo, Editora 34, 2010, p. 8) No mesmo sentido, e citando o mesmo livro do filósofo alemão, Teresa Ancona Lopez afirma: “[...] por mais medidas que sejam tomadas, o risco zero não existe. Em suma, a única certeza na sociedade risco é a incerteza, pois os riscos não podem ser mensurados. A sociedade de risco, como quer Beck, é a sociedade da
} 
Como pontua Ulrick Beck ${ }^{186}$, "na modernidade tardia, a produção social de riqueza é acompanhada sistematicamente pela produção social de riscos." (destaques do autor)

O risco, que antes tinha uma dimensão pessoal ${ }^{187}$, adquiriu também dimensão global, como ocorre hoje em dia com a chuva ácida, o buraco na cama de ozônio, as guerras nucleares, ou até mesmo riscos relacionados a investimentos, bolsas de valores, crises econômicas dentre outros. Houve, portanto, mudança na escala dos riscos, com a globalização dos fenômenos econômicos e o aumento da velocidade de difusão das consequências.

Fazendo uso da expressão de Beck, "a palavra 'risco' tinha, no contexto daquela época [referindo-se às grandes navegações], um tom de ousadia e aventura, e não o da possível autodestruição da vida na Terra."

Registrou-se uma mudança da percepção do risco e do sentimento que o homem passa a ter de que qualquer dano deve ser imputado a uma pessoa. A indenização é cada vez mais procurada. Como ensina Marcelo Dias Varella ${ }^{188}$, os homens, ao invés de resignarem-se ou implorarem aos deuses, passam a preferir se dirigir às autoridades ou a quem lhes causou o dano. A ideia de socorro evoluiu, com o tempo, para a de indenização.

Frente ao risco, a evolução atual da sociedade é marcada por um paradoxo: fortalecendo a segurança, ela faz desaparecer, previne ou limita o número de riscos, mas provoca outros ao mesmo tempo e suscita uma forte demanda de prevenção e de cobertura. Além disso, riscos considerados anteriormente como devendo ser assumidos individualmente são, hoje, vistos como sendo da responsabilidade da comunidade. ${ }^{189}$

era industrial acrescida das inovações científicas e tecnológicas, cujos efeitos são imprevisíveis.” (LOPEZ, Teresa Ancona; LEMOS, Patrícia Fraga Iglecias; RODRIGUES JUNIOR, Otavio Luiz. (coord.) Responsabilidade Civil na Sociedade de Risco in Sociedade de Risco e Direito Privado - desafios normativos, consumeristas e ambientais. São Paulo: Atlas, 2013, p. 5)

${ }^{186}$ OP. cit, p. 23.

${ }^{187}$ V.g. Morrer, invalidar-se, passar fome, ter um bem incendiado etc.

${ }^{188}$ Op. cit., p. 36.

${ }^{189}$ VARELLA, Marcelo Dias. Op. cit., p. 231. 
E Varella continua ${ }^{190}$ :

Os riscos são, sensivelmente, mais difusos em suas causas como em seus efeitos. O responsável pelo dano é, por sua vez, mais difícil de individualizar, em razão da multiplicidade das cadeias de produção tanto quanto de decisão. Somos confrontados com riscos que resultam em sequências complexas de fatores cujas causas são dificilmente identificadas.

No mesmo sentido é a doutrina da Teresa Ancona Lopez ${ }^{191}$, que defende:

A doutrina da "socialização dos riscos" tem fundamento ético na solidariedade social como necessidade de reparação integral de todos os danos. Há de se proteger as vítimas. Os riscos criados não se consideram mais simples riscos individuais. São riscos sociais e não é justo que os homens respondam por eles individualmente.

Segundo Beck ${ }^{192}$, a natureza foi "subjugada e explorada no final do século XX e, assim, transformada de fenômeno externo em interno, de fenômeno predeterminado em fabricado. Ao longo de sua transformação tecnológico-industrial e de sua comercialização global, a natureza foi absorvida pelo sistema industrial." (grifos do autor)

Ulrich Bech ${ }^{193}$ arremata:

A sociedade de risco é, em contraste com todas as épocas anteriores (incluindo a sociedade industrial), marcada fundamentalmente por uma carência: pela impossibilidade de imputar externamente as situações de perigo. À diferença de todas as culturas e fases de desenvolvimento social anteriores, que se viam confrontadas a ameaças das mais variadas formas, atualmente a sociedade se vê, ao lidar com riscos, confrontada consigo mesma. (destaques do autor)

$\mathrm{O}$ que se pretende demonstrar com essas breves considerações, ainda que não estejam diretamente relacionadas com o objeto dessa dissertação, é o paradoxo entre o momento de criação do seguro (que será analisado no tópico a seguir) e a evolução pela qual passou o instituto ao longo de milhares de anos. Embora se tenha verificado um

\footnotetext{
${ }^{190}$ Idem, p. 34.

${ }^{191}$ Op. cit., p. 11.

192 Op. cit., p. 9.

193 Op. cit., p. 275.
} 
progresso na sociedade, continuamos expostos a riscos, ainda que de outras naturezas e dimensões.

Traçando-se um paralelo com a previdência, é possível constatar que, se antes um dos principais desafios humanos era garantir sua sobrevivência diante de tantas adversidades ${ }^{194}$, hoje em dia, em que boa parte dessas questões encontrou solução, o homem depara-se com outro desafio: sua própria longevidade.

Com relação especificamente ao seguro de vida, observa-se também uma importante mudança. $\mathrm{O}$ produto que foi originalmente concebido para proteger terceiros em caso de morte do segurado, atualmente, parece ter perdido essa importância frente ao seguro por sobrevivência, por exemplo, pois parece que no momento atual, pior que ter de lidar com as consequências econômicas de uma pessoa que faleceu é ter de enfrentar uma longa velhice sem recursos financeiros para tal ${ }^{195}$.

\subsection{Breve história do seguro}

A história do seguro confunde-se em certa medida com a da previdência, pois tanto um como outro são mecanismos de proteção contra riscos futuros, e têm sua origem remota na solidariedade entre os seres humanos.

Entretanto, como visto, no caso da previdência, essa proteção acabou por se restringir aos riscos sociais ${ }^{196}$ e ao papel do Estado na proteção contra eles, despontando a

\footnotetext{
${ }^{194}$ V.g. as doenças que não tinham cura, a falta de saneamento básico, a ausência de mecanismos eficazes de proteção contra os acidentes.

195 Neste sentido, é a lição de Carlos José María Facal (op. cit., pp. 5-6): O acesso a novos conhecimentos, por sua vez, permite novas oportunidades para ampliar o conhecimento de todos os tipos. Um dos frutos do progresso tem sido o prolongamento extraordinário da duração da sua própria vida e o aumento do seu tempo livre. (...) O seguro de vida, projetado para proteger terceiros em caso de morte do segurado, perdeu importância com relação ao seguro por sobrevivência ou a previdência, salvo nos casos em que este também seja capaz de servir como um verdadeiro veículo de poupança para a velhice. (tradução livre) "El acceso a nuevos conocimientos permite a su vez nuevas oportunidades de expandir los saberes de toda índole. Uno de los frutos del progreso ha sido la extraordinaria prolongación de la duración de su propia vida y el aumento de su tempo libre. (...) El seguro de vida, pensado para proteger a terceros en caso de fallecimiento del asegurado, ha perdido importancia relativa frente al seguro de supervivencia o de retiro, salvo en los casos en que también es capaz de servir como un verdadero vehículo de ahorro para la vejez."

${ }^{196}$ Que afetam o homem fundamentalmente com relação à sua vida laborativa.
} 
previdência privada como um sistema de complementação desse regime social. Já os seguros, por sua vez, ficaram com um espectro mais amplo, podendo também referir-se a riscos sociais, mas não só. Assim, o seguro ${ }^{197}$, do ponto de vista da sua concepção, acaba sendo um gênero do qual a previdência tornou-se uma espécie.

Por essa razão é que, embora o seguro e previdência tenham uma mesma raiz, é possível contar a história de um e de outro sob diferentes ângulos.

Não se pretende neste tópico fazer uma investigação exaustiva a respeito de todos os fatos que marcaram a história do seguro, o que escaparia ao objeto desta dissertação. Pretende-se ilustrar a história da solidariedade que evoluiu para o que se chamou de mutualismo, desvinculado do papel do Estado, a partir do momento em que se entendeu que tal estrutura adquiriu os contornos do contrato de seguro, por meio da utilização de cálculos estatísticos e atuariais.

Já na Antiguidade ${ }^{198}$ havia mecanismos de solidariedade que tinham por base o mutualismo, contudo não chegavam a reunir elementos significativos para caracterizá-los como seguros, pois, como afirma Menezes Cordeiro ${ }^{199}$, o que tais mecanismos conseguiam era uma dispersão do risco, não se constituindo um tipo negocial que, de modo expresso e assumido, se destinasse a essa finalidade.

Afirma-se que o seguro propriamente dito surgiu na época das grandes navegações, na Idade Média, quando se percebeu que todos aqueles expostos a um risco similar compartilhavam sua sorte, e que a criação de um mecanismo de compartilhamento de riscos traria maior proteção. Os seguros privados, portanto, possuem origem marítima, fortemente ligada à Inglaterra e à Itália.

\footnotetext{
${ }^{197}$ Em lato sensu, entendido como instrumento de proteção, mas não necessariamente em strictu sensu, no sentido dos elementos que constituem um e outro, uma vez que ambos acabaram, com a evolução pela qual passaram ao longo dos séculos, adquirindo contornos peculiares, especialmente com relação aos planos de mera acumulação.

${ }^{198}$ Antonio Menezes Cordeiro (op. cit., pp. 50-57) cita pelo menos três exemplos: (i) o Código de Hamurabi (1800 a.C.) previa normas relativas ao risco de operações comerciais que poderiam ser consideradas com os antepassados longínquos do contrato de seguro; (ii) o empréstimo marítimo da Grécia Antiga (a partir do século IV a.C), que previa uma garantia ou "suportação do risco" semelhante ao que ocorre no atual seguro prestamista; (iii) em Roma Antiga, os empréstimos marítimos (phoenus nauticum) que quase sempre vinham com uma cláusula penal, por meio da qual o prestamista assumia os riscos graves.

${ }^{199}$ Idem, ibidem.
} 
Neste sentido é a lição de Lowry, Rawlings e Merkins ${ }^{200}$ :

O seguro tem uma história que parece remeter aos babilônios e certamente foi bem estabelecido entre as cidades e guildas da Europa de meados do século XIV. No entanto, foi o rápido crescimento do comércio internacional por via marítima a partir do século XV, que se centralizou, sobretudo, em torno das cidades-Estado italianas, que levou ao desenvolvimento por esses Estados de métodos reconhecidamente modernos de seguro. (Tradução livre)

\subsection{O surgimento do seguro privado no Brasil}

O seguro privado no Brasil, guardando também alguma semelhança com a história da previdência privada nacional, embora conte com mais de 200 anos de existência, teve seu apogeu em nosso país nas últimas décadas, o que foi propiciado pelo contexto político e econômico recente ${ }^{201}$.

Seu advento no país foi com a chegada da família real, em 1808, por meio da criação da Companhia de Seguros Boa Fé, no mesmo ano, destinada ao ramo marítimo ${ }^{202}$.

Entretanto, nos seus primeiros anos de história, os seguros não tiveram grande desenvolvimento no país. Como explicam Marcelo de Paiva Abreu e Felipe Tâmega Fernandes $^{203}$ :

No entanto, o desenvolvimento deste negócio [seguro] seria muito lento, devido à falta de oportunidades econômicas e instabilidade política. O quadro

\footnotetext{
200 "Insurance has a history that appears to go back on the Babylonians and was certainly well established among the towns guilds of Europe by the mid-fourteenth century. However, it was the rapid growth in international trade by sea from the fifteenth century, which was centered, in particular, around the great Italian city states, that led to the development by those states recognizably modern methods of insurance." (LOWRY, John; RAWLINGS, Philip; MERKIN, Robert. Insurance Law. Doctrines and Principles. $3^{\mathrm{a}} \mathrm{ed}$. Oxford: Hart Publishing, 2011. p. 1.)

${ }^{201}$ V.g. A estabilidade econômica propiciada pelo Plano Real, a flexibilização das normas referentes ao mercado securitário, que permitiu a instalação de seguradoras estrangeiras, a abertura do mercado de resseguro por meio da LC 126/07.

202 Informações obtidas no endereço eletrônico da SUSEP. Disponível em: <http://www2.susep.gov.br/menususep/historiadoseguro.asp>. Acesso em 09/10/13.

203 "However, the development of this business would be very slow, due to the lack of economic opportunities and political instability. The institutional framework was very lax and not adapted to the specificities of the country as early legislation on insurance was borrowed from Portugal." The insurance industry in Brazil: a long-term view. Working Paper 10-109, Harvard Business School, 2010, p. 3. Disponível em <http://www.hbs.edu/faculty/Publication\%20Files/10-109.pdf>, acesso em 21/12/13.
} 
institucional era muito negligente e não adaptado às especificidades do país, como a legislação no início de seguros foi "emprestada" de Portugal. (Tradução livre)

Até 1860, 18 seguradoras haviam sido instaladas no país, as quais operavam principalmente no seguro marítimo, mas também com seguro de vida, de escravos ${ }^{204}$, empresarial e incêndio ${ }^{205}$.

Nas últimas décadas do século XIX, o desenvolvimento do setor no Brasil relacionou-se com a Inglaterra e o café, "na medida em que a proliferação das companhias de seguro, principalmente inglesas, se deu a partir do auge da exportação do café."206

Durante a Era Vargas, os seguros estavam fortemente impregnados por questões trabalhistas como, por exemplo, as primeiras tentativas de transferir o seguro de acidentes de trabalho para o Estado, o que acabou por se concretizar somente mais tarde, durante o regime militar. ${ }^{207}$

Outra característica marcante do Estado Novo foi o estabelecimento, com a promulgação da Constituição de 1937 do "Princípio de Nacionalização do Seguro", que já havia sido indicado na Constituição de 1934. Em consequência, foi promulgado o Decreto $\mathrm{n}^{\circ}$ 5.901, 1940, “criando os seguros obrigatórios para comerciantes, industriais e concessionários de serviços públicos, pessoas físicas ou jurídicas, contra os riscos de incêndios e transportes (ferroviário, rodoviário, aéreo, marítimo, fluvial ou lacustre)”208

Marcou ainda essa época a criação do Instituto de Resseguros do Brasil - IRB, em 1939, obrigando as seguradoras a ressegurar no Instituto as responsabilidades que excedessem sua capacidade de retenção técnica própria. "Com esta medida, o Governo Federal procurou evitar que grande parte das divisas fosse consumida com a remessa, para

\footnotetext{
${ }^{204}$ Considerados propriedade, na altura.

205 ABREU, Marcelo de Paiva e FERNANDES Felipe Tâmega. Op. cit., p. 3.

${ }^{206}$ ALBERTI, Verena (coord.). Entre a solidariedade e o risco: história do seguro privado no Brasil. $2^{\mathrm{a}}$ Ed. Rio de Janeiro: 2001, p. 14.

${ }^{207}$ ALBERTI, Verena, idem, ibidem. A autora cita como outro exemplo dessa mistura do seguro às questões trabalhistas durante a Era Vargas o fato de os seguros, que de 1901 (data da criação da Superintendência Geral de Seguros) a 1933, as operações de seguros eram subordinadas ao Ministério da Fazenda. A partir de então, passaram a se submeter ao Minstério do Trabalho, Indústria e Comércio, onde permaneceram até 1961, com a criação do Ministério da Indústria e Comércio.

${ }^{208}$ Fonte: <http://www.susep.gov.br/menu/a-susep/historia-do-seguro>, acesso em 21/12/13.
} 
o exterior, de importâncias vultosas relativas a prêmios de resseguros em companhias estrangeiras." 209

$\mathrm{Na}$ época da Segunda Guerra Mundial, tiveram impulso os ramos de seguros de casco marítimo e de transporte de mercadorias, conhecidos como "riscos de guerra". ${ }^{210}$

Durante a segunda metade do século XIX, o mercado de seguros brasileiro caracterizou-se pela nacionalização e restrição a entrada de seguradoras estrangeiras. As décadas de 80 e 90 foram marcadas por uma inflação avassaladora até que, em 1993, com o Plano Real e estabilidade econômica, o mercado de seguros ganhou condições favoráveis ao seu desenvolvimento.

Como explicam Marcelo de Paiva Abreu e Felipe Tâmega Fernandes ${ }^{211}$ :

Desde o início de 1990, o modelo de autarquia e intervenção estatal intensa começou a ser exaustivamente revisto, e houve uma redução significativa do protecionismo, considerável desregulamentação e privatização de muitas estatais começando pelas indústrias e, em seguida, que afetaram os prestadores de serviços públicos, como telecomunicações e energia elétrica. Em 1993-1994, a inflação crônica foi finalmente domada com a implementação do Plano Real.

Os números atuais do mercado securitário brasileiro podem ser vistos no gráfico a seguir, que demonstra um salto na penetração do mercado de seguros e previdência privada aberta com relação ao PIB nacional:

\section{Gráfico 7 - Coeficiente de penetração do mercado de seguros e previdência privada}

\section{aberta}

\footnotetext{
${ }^{209}$ Fonte: <http://www.susep.gov.br/menu/a-susep/historia-do-seguro>, acesso em 21/12/2013.

${ }^{210}$ Alberti Verena. Op. cit., p. 14.

211 "From the early 1990s the model of autarchy and heavy state intervention started to be comprehensively revised and there was a significant reduction of protection, considerable deregulation and privatization of many state-owned concerns starting with industrial firms and then affecting providers of public services such as telecoms and electricity. In 1993-1994 chronic inflation was finally tamed with the implementation of the Real Plan.” Op. cit, p. 27.
} 


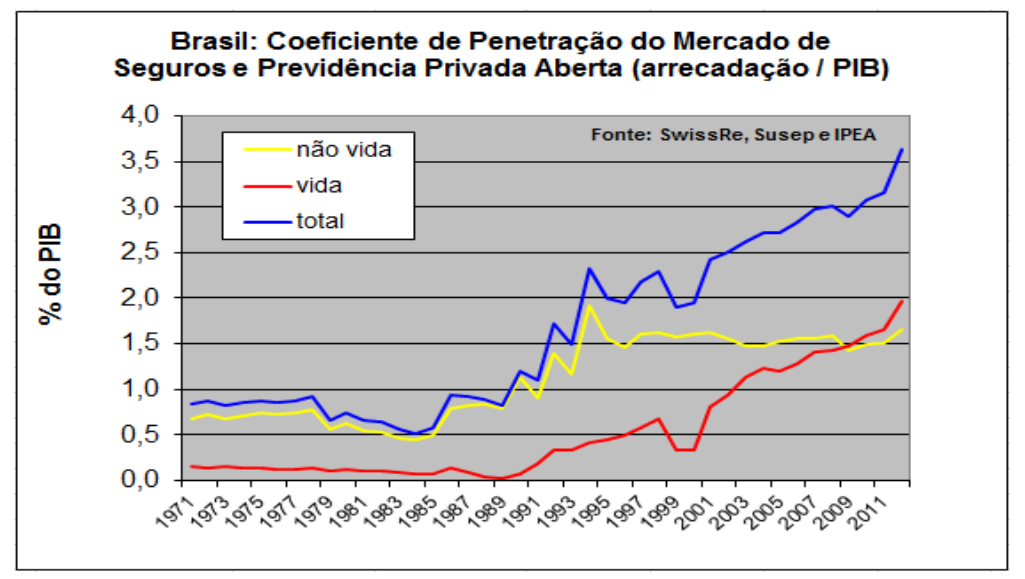

\subsection{Arcabouço jurídico}

Do ponto de vista jurídico, o Código Comercial de 1850 regulamentou somente o contrato de seguro marítimo. Em 1916, o primeiro Código Civil tratou do seguro em geral, com a dedicação de todo um capítulo à matéria, abrangendo seguros matítimos e não marítimos, seguros de vida e seguros mútuos, sendo muito mais abrangente do que o diploma de 1850 .

Da legislação vigente aplicável merece também destaque o DL 73/66, que trata da operação securitária como um todo, disciplinando o Sistema Nacional de Seguros Privados, regulando as operações de seguros e resseguros.

Atualmente, além das normas do DL e do $\mathrm{CC} 02^{212}$, há ainda um “emaranhado" de normativos infralegais emanados pela Susep e pelo CNSP, que regulamentam de maneira detalhada os mais variados ramos, produtos e procedimentos relacionados a seguros.

\subsection{Seguro social e seguro privado}

\footnotetext{
${ }^{212}$ Há em tramitação na Câmara dos Deputados um projeto de lei (PL 8034/2010, sucessor do PL 3555/04), o qual se propõe a regular o contrato de seguro e revogar alguns artigos do capítulo do CC02 a respeito do tema. Iniciativas semelhantes, no sentido de se tratar o contrato de seguro em legislação independente já existem em diversos países, como Portugal, Espanha, França, Itália, Bélgica, Alemanha Cuba, Argentina, Canadá, México e Venezuela.
} 
Uma vez que se pretende analisar a previdência privada à luz do Direito do seguro, e reconhecido que ambos convergem na sua origem (por terem evoluído do ideal de solidariedade) e na finalidade de proteção $^{213}$, partiremos da análise dos elementos técnicos e jurídicos dos seguros sociais e privados, com o objetivo de distingui-los.

O seguro, por ter como fundamento o mutualismo ${ }^{214}$, é um mecanismo que demanda uma massa de aderentes para poder se sustentar. Contudo, nem todos têm condições para arcar com o pagamento do prêmio: há pessoas cuja remuneração só é suficiente para sua subsistência. Enquanto gozam de boas condições de saúde, veem atendidas suas necessidades básicas, mas, quando enfrentam alguma situação de risco, ficam com poucas opções para recorrer. No passado, como vimos, essas pessoas muitas vezes se valiam do apoio de instituições religiosas ou de caridade.

Com o passar do tempo, o Estado assumiu papel de amparo dessa parte da população, por meio do seguro social, de origem securitária que, entretanto, afastou-se para criar um fenômeno independente, não só em termos jurídicos, mas também no que toca aos aspectos técnicos e econômicos ${ }^{215}$.

\subsubsection{Forma de filiação}

Os seguros sociais não decorrem da vontade individual das partes; o segurado não tem opção de recusar a adesão ao sistema, pois sua compulsoriedade resulta da lei ${ }^{216}$, fonte do regulamento contratual.

Sobre este tema, Pontes de Miranda ensina ${ }^{217}$ :

\footnotetext{
${ }^{213}$ Neste sentido é a doutrina de Eliane Romeiro Costa (Op. cit., p. 12): “A finalidade securitária constitui o motor do sistema pecuniário". Entendemos por finalidade previdenciária a manutenção das regras que originaram o objeto do contrato de seguro social, público e privado. O sistema, como unidade previdenciária, insculpido no sistema constitucional forma as bases das relações jurídicas do seguro previdenciário. A condição de segurado no Sistema social e no Regime Complementar apresenta-se distintamente: em primeiro lugar nos aspectos da forma de filiação, de adesão e de contribuição; em segundo lugar, nas estruturas do contrato de prestação ou de benefício previdenciário.

${ }^{214}$ Vide infra 3.8.2.

${ }^{215}$ DONATI, Antigono; PUTZOLU, Giovanna Volpe. 10a ed. Manuale di Diritto Delle Assicurazioni. Milão: Giuffrè, 2012, p. 7.

${ }^{216}$ Lei $\mathrm{n}^{\circ} 8.212 / 91$, que define no art. 12 os segurados obrigatórios da previdência social.

${ }^{217}$ MIRANDA, Pontes de. Tratado de Direito Privado. Campinas: Bookseller, 2006, pp. 408-409.
} 
[...] a propósito dos seguros sociais, por tal modo se foi limitando o autoregramento da vontade que a publicização como que apagou a negociabilidade bilateral. As prestações passaram a ser automáticas, e às vezes, sem qualquer manifestação de vontade da pessoa a que se promete o seguro, a contraprestação. (...) Contudo, a publicização não atinge a natureza do seguro.

São seguros impostos à coletividade, que têm por objetivo amparar parte da população, sobretudo a classe trabalhadora, contra determinados riscos, tais como a morte, acidentes, invalidez, doenças, desemprego ou maternidade, entendidos como riscos que decorrem da própria vida em sociedade.

Eliane Romeiro Costa ${ }^{218}$, a respeito da compulsoriedade do seguro social, explica que o seu fundamento é o fomento do sistema, tendo em vista a escassa adesão voluntária. Para ela, essa baixa adesão seria motivada por uma falta de consciência coletiva a respeito da necessidade de uma poupança social compulsória, e por fatores econômicos e de desemprego, que levariam o trabalhador de baixa renda a não contribuir, por ter outras prioridades imediatas.

Conclui a autora ${ }^{219}$ que "o seguro social, como seguro compulsório, fundou-se em uma medida coercitiva. Equivale a considerar que a atitude caritativa não produz relações socialmente equânimes ou que o indivíduo isolado tampouco se preocupa com o seu futuro."

Já no caso dos seguros privados, não existe, em regra geral ${ }^{220}$, obrigatoriedade na contratação do seguro. A base da relação é um acordo de vontades, estabelecido livremente entre as partes.

\footnotetext{
${ }^{218}$ Op. cit., p. 64.

${ }^{219}$ Idem, ibidem.

${ }^{220}$ A exceção são os seguros obrigatórios, tais como os descritos no art. 20 do DL 73/66: "Sem prejuízo do disposto em leis especiais, são obrigatórios os seguros de: a) danos pessoais a passageiros de aeronaves comerciais; b) responsabilidade civil do proprietário de aeronaves e do transportador aéreo; c) responsabilidade civil do construtor de imóveis em zonas urbanas por danos a pessoas ou coisas; d) bens dados em garantia de empréstimos ou financiamentos de instituições financeiras públicas; e) garantia do cumprimento das obrigações do incorporador e construtor de imóveis; f) garantia do pagamento a cargo de mutuário da construção civil, inclusive obrigação imobiliária; g) edifícios divididos em unidades autônomas; h) incêndio e transporte de bens pertencentes a pessoas jurídicas, situados no País ou nêle transportados; j) crédito à exportação, quando julgado conveniente pelo CNSP, ouvido o Conselho Nacional do Comércio Exterior (CONCEX); 1) danos pessoais causados por veículos automotores de vias terrestres e por embarcações, ou por sua carga, a pessoas transportadas ou não; m) responsabilidade civil dos transportadores
} 
Vera Helena de Mello Franco ${ }^{221}$ adverte, contudo, que, embora os seguros privados estejam submetidos a normas de Direito Público e Privado, onde se percebe nitidamente o dirigismo do Estado em tais contratos, esse fato não lhes retirar a feição contratual de seguros privados:

Os contratos de seguros privados abrangem as operações individuais (por oposição ao seguro social, como ocorre com a previdência social). $\mathrm{O}$ acordo de vontades está na base da relação, mas ao seu lado tem-se uma fonte concorrente de condições para a formatação do regulamento contratual, representada por cláusulas impostas pelo Poder Público que atuam, não só com relação ao impulso para contratar, obrigando a contratação (seguro obrigatório), como no seu conteúdo, mediante a inserção de cláusulas obrigatórias advindas das condições gerais dos seguros privados. Cuida-se, assim de contrato dirigido ou regulamentado, posto que o conteúdo geral de cada contrato não se regula por pactos variáveis de contrato para contrato, mas, sim, por normas prefixadas nas condições gerais emanadas pela SUSEP. Isto, porém, não veda a presença de cláusulas facultativas de escolha livre das partes.

\subsubsection{Financiamento}

O seguro social conta com financiamento tripartido, na medida em que empregados, empregadores e o próprio Estado contribuem para seu custeio ${ }^{222}$.

Daniel Pulino ${ }^{223}$ explica que o princípio da diversidade da base de financiamento "reflete a preocupação de não se restringir o custeio da seguridade social a uma única base, o que poderia colocá-lo em risco se, por qualquer razão, restasse afetada a fonte única de

terrestres, marítimos, fluviais e lacustres, por danos à carga transportada. Tais seguros, embora privados, no sentido de serem operados por entidades de direito privado, são se contratação obrigatória pelo seu caráter social.

${ }^{221}$ Contratos no direito privado: direito civil e empresarial. $3^{\mathrm{a}}$ ed. São Paulo: Revista dos Tribunais, 2012, pp. 296-297.

Sobre a diversidade de base de financiamento da seguridade social, a CF estabelece no art. 195: "A seguridade social será financiada por toda a sociedade, de forma direta e indireta, nos termos da lei, mediante recursos provenientes dos orçamentos da União, dos Estados, do Distrito Federal e dos Municípios, e das seguintes contribuições sociais: I - do empregador, da empresa e da entidade a ela equiparada na forma da lei, incidentes sobre: a) a folha de salários e demais rendimentos do trabalho pagos ou creditados, a qualquer título, à pessoa física que lhe preste serviço, mesmo sem vínculo empregatício; b) a receita ou o faturamento; c) o lucro; II - do trabalhador e dos demais segurados da previdência social, não incidindo contribuição sobre aposentadoria e pensão concedidas pelo regime geral de previdência social de que trata o art. 201; III - sobre a receita de concursos de prognósticos; IV - do importador de bens ou serviços do exterior, ou de quem a lei a ele equiparar."

${ }^{223}$ Op. cit, p. 33. 
captação dos recursos necessários para desenvolvimento de prestações tão importantes para a própria sobrevivência do corpo social".

De outra ponta, nos seguros privados, o pagamento do prêmio não tem caráter universal, pois não é financiado pela sociedade como um todo. Ele pode ser pago pelo próprio segurado, pelo estipulante ou pelo tomador do seguro, somente.

Evidencia-se, portanto, o caráter social dos primeiros, e privado dos segundos, já que aqueles são de interesse da sociedade como um todo, e estes, ainda que também possam dizer respeito a riscos que afetem toda ou boa parte da coletividade, restringem-se à esfera privada, não sendo permeados pelo ideal de seguridade.

\subsubsection{Instrumentalização da relação}

Nos seguros sociais não existe uma "apólice" (instrumento do contrato de seguro privado). São outros os documentos que comprovam a condição de segurado, tais como os "carnês" de pagamento da contribuição social e os próprios extratos emitidos pelas agências da Previdência Social.

Nos seguros privados, em regra geral $^{224}$, há uma apólice, bilhete ${ }^{225}$ ou certificado $^{226}$ que descreve os riscos cobertos e comprova a inclusão do segurado no seguro.

\subsubsection{Tipos de riscos cobertos}

A proteção ao trabalhador nos seguros sociais diz respeito aos riscos que afetam unicamente sua renda pessoal (e não o seu patrimônio, por exemplo).

\footnotetext{
${ }^{224}$ Pode ocorrer, eventualmente, de faltar a apólice. Do ponto de vista da comprovação do contrato, essa falta poderá ser suprida pela comprovação do pagamento do prêmio, conforme o art. 758 do Código Civil.

${ }^{225}$ Como destaca Vera Helena de Mello Franco (Contratos, op. cit., p. 309), "a apólice e/ou o bilhete de seguro comprovam a aceitação e a existência do seguro. Mas a apólice não é o contrato, e sim o instrumento que evidencia o contrato de seguro."

${ }^{226}$ No caso dos seguros coletivos.
} 
Por outro lado, temos os seguros privados, cuja definição consta do art. $3^{\circ}$ do DL 73/66:

Consideram-se operações de seguros privados os seguros de coisas, pessoas, bens, responsabilidades, obrigações, direitos e garantias. Parágrafo único. Ficam excluídos das disposições dêste Decreto-lei os seguros do âmbito da Previdência Social, regidos pela legislação especial pertinente. (n.g.)

Neles há proteção contra qualquer tipo de risco, pessoal ou patrimonial, desde que esteja dentro dos limites de possibilidade e capacidade técnica da seguradora. A proteção não é só contra os riscos relacionados com a renda ou situação de emprego do segurado, como ocorre nos seguros sociais.

Como sintetiza Eliane Romeiro Costa ${ }^{227}$ :

As regras do seguro social garantem proteção aos segurados contra as consequências econômicas dos riscos que podem diminuir ou extinguir a capacidade do homem para o trabalho, enquanto o seguro privado "não protege" os riscos da mesma forma. Ele é de outra natureza.

\subsubsection{Solidariedade e mutualismo}

Donati e Putzolu ${ }^{228}$ destacam ainda outra diferença entre o seguro privado e o social. Segundo os autores, no primeiro haveria mutualismo e, no segundo, solidariedade:

A mutualidade, entendida no sentido técnico e econômico como um mecanismo de repartição dos encargos entre todas as partes em situação de risco, é operação de seguro típico descrito nos parágrafos anteriores,

\footnotetext{
${ }^{227}$ Op. cit., p. 70.

228 "La mutualitá, intesa in senso tecnico ed economico, in quanto meccanismo di distribuzione degli oneri tra tutti i soggetti esposti al rischio, é tipica dell'operazione assicurativa descritta nei precedenti paragrafi, vale a dire dell'assicurazione privata. Nella solidarietà, che invece caratterizza le assicurazioni sociali, manca, in tutto o in parte, l'identità tra soggetti esposti al rischio e coloro tra i quali sono ripartiti i relativi oneri, manca in altre parole il requisito della reciprocità fra il soggeti esposti al rischio, che è tipico delle assicurazioni private. Con il sistema finanziario "di ripartizione", oltre alla redistribuzione solidaristica che si verifica tra gli individui entrati in assicurazione alla stessa epoca, viene realizzata un'ulteriore redistribuzione tra generazioni, nel senso che una parte almeno degli oneri delle prime generazioni risulta sostenuta da quelli che entreranno successivamente nella gestione." (DONATI, Antigono; PUTZOLU, Giovanna Volpe). Op. cit., p. 7.
} 
ou seja, dos seguros privados. Na solidariedade, que, diferentemente, caracteriza os seguros sociais, o que falta é uma identidade entre os sujeitos em situação de risco e as pessoas com as quais são repartidos os custos relacionados. Em outras palavras, falta a exigência de reciprocidade entre os indivíduos expostos a risco, o que é típico dos seguros privados. Com o sistema financeiro de "repartição simples", bem como com a redistribuição da solidariedade que ocorre entre os indivíduos que aderiram ao seguro ao mesmo tempo, é realizada uma redistribuição entre gerações, no sentido de que pelo menos uma parte do custo das primeiras gerações é suportado por aqueles que entrarem mais tarde nesse seguro. (Tradução livre) (n.g.)

Os autores referem-se ao princípio da solidariedade, que rege os seguros sociais, mas não os seguros privados. Por trás dos seguros sociais existem duas concepções: distributiva e comutativa.

Conforme a doutrina de Marcus Orione Correia e Erica Barcha Correia ${ }^{229}$, "segundo a concepção comutativa, a seguridade social funciona como um sistema de garantias de rendas obtidas pelo exercício de determinada atividade profissional e destinadas à cobertura de riscos previamente catalogados." Os mesmos autores relacionam a concepção distributiva ao ideal de solidariedade, a exemplo do trecho acima transcrito da doutrina italiana:

\begin{abstract}
Segundo a concepção distributiva, o exercício de uma atividade profissional deixa de ser o elemento fundamental do direito à seguridade social. Aqui, o objeto é a necessidade dos indivíduos, levando-se em consideração a existência de outras necessidades sociais, novas, chamadas coletivas. O que se depreende é que, lentamente, vai-se firmando a ideia de solidariedade, na qual a coletividade é que deve tomar para si as prestações destinadas a garantir a todos os seus membros uma renda mínima, a título de participação no nível geral do bem-estar. Trata-se de assegurar uma melhor distribuição das rendas em função das necessidades do indivíduo.
\end{abstract}

Fica clara a diferença entre seguros privados e sociais, sob esse ponto de vista. Nos seguros privados não há distribuição de renda em função de necessidades sociais. $\mathrm{O}$ que existe é um verdadeiro negócio jurídico, por meio do qual as partes convencionam repartir as consequências danosas dos eventos a que estão expostas, por meio do mutualismo - e não da solidariedade.

${ }^{229}$ Op. cit., p. 16. 
Ainda que o seguro tenha suas origens remotas no ideal de solidariedade, por meio da sua evolução acabou por se afastar desse conceito, e a repartição de riscos, que outrora teve caráter de ajuda mútua e caridade, adquiriu a concepção de operação de pulverização de riscos, tendo suas operações fundamentadas em cálculos probabilísticos, estatísticos e atuariais.

\subsubsection{Administração}

Outra diferença relevante entre o seguro social e o privado é que o primeiro é administrado pelo Estado, por meio do Instituto Nacional do Seguro Social (INSS) ${ }^{230}$, enquanto os segundos são operados por entidades de direito privado, sob a supervisão do Estado, por meio do $\mathrm{CNSP}^{231}$ e da $\mathrm{SUSEP}^{232}$.

${ }^{230}$ Nos termos do art. $1^{\circ}$ do Anexo I do Decreto no 7.556/11: "O Instituto Nacional do Seguro Social - INSS, autarquia federal com sede em Brasília - Distrito Federal, vinculada ao Ministério da Previdência Social, instituída com fundamento no disposto no art. 17 da Lei no 8.029, de 12 de abril de 1990, tem por finalidade promover o reconhecimento de direito ao recebimento de benefícios administrados pela Previdência Social, assegurando agilidade, comodidade aos seus usuários e ampliação do controle social."

${ }^{231}$ Consoante o art 32 do DL 73/66: "É criado o Conselho Nacional de Seguros Privados - CNSP, ao qual compete privativamente: I - Fixar as diretrizes e normas da política de seguros privados; II - Regular a constituição, organização, funcionamento e fiscalização dos que exercerem atividades subordinadas a êste Decreto-Lei, bem como a aplicação das penalidades previstas; III - Estipular índices e demais condições técnicas sôbre tarifas, investimentos e outras relações patrimoniais a serem observadas pelas Sociedades Seguradoras; IV - Fixar as características gerais dos contratos de seguros; V - Fixar normas gerais de contabilidade e estatística a serem observadas pelas Sociedades Seguradoras; VI - delimitar o capital das sociedades seguradoras e dos resseguradores; VII - Estabelecer as diretrizes gerais das operações de resseguro; VIII - Disciplinar as operações de cosseguro, nas hipóteses em que o IRB não aceite resseguro do risco ou quando se tornar conveniente promover melhor distribuição direta dos negócios pelo mercado; VIII disciplinar as operações de co-seguro; IX - Conhecer dos recursos de decisão da SUSEP e do IRB, nos casos especificados neste Decreto-Lei; X - Aplicar às Sociedades Seguradoras estrangeiras autorizadas a funcionar no País as mesmas vedações ou restrições equivalentes às que vigorarem nos países da matriz, em relação às Sociedades Seguradoras brasileiras ali instaladas ou que nêles desejem estabelecer-se; XI - Prescrever os critérios de constituição das Sociedades Seguradoras, com fixação dos limites legais e técnicos das operações de seguro; XII - Disciplinar a corretagem de seguros e a profissão de corretor; XIV - Decidir sôbre sua própria organização, elaborando o respectivo Regimento Interno; XV - Regular a organização, a composição e o funcionamento de suas Comissões Consultivas; XVI - Regular a instalação e o funcionamento das Bolsas de Seguro. XVII - fixar as condições de constituição e extinção de entidades autorreguladoras do mercado de corretagem, sua forma jurídica, seus órgãos de administração e a forma de preenchimento de cargos administrativos; XVIII - regular o exercício do poder disciplinar das entidades autorreguladoras do mercado de corretagem sobre seus membros, inclusive do poder de impor penalidades e de excluir membros; XIX disciplinar a administração das entidades autorreguladoras do mercado de corretagem e a fixação de emolumentos, comissões e quaisquer outras despesas cobradas por tais entidades, quando for o caso."

${ }^{232}$ Conforme o art 36 do DL 73/66: "Compete à SUSEP, na qualidade de executora da política traçada pelo CNSP, como órgão fiscalizador da constituição, organização, funcionamento e operações das Sociedades Seguradoras: a) processar os pedidos de autorização, para constituição, organização, funcionamento, fusão, encampação, grupamento, transferência de contrôle acionário e reforma dos Estatutos das Sociedades Seguradoras, opinar sôbre os mesmos e encaminhá-los ao CNSP; b) baixar instruções e expedir circulares relativas à regulamentação das operações de seguro, de acôrdo com as diretrizes do CNSP; c) fixar condições de apólices, planos de operações e tarifas a serem utilizadas obrigatòriamente pelo mercado segurador 


\subsection{A previdência privada não é um seguro social}

Logo, e diante de todo o exposto, é possível reconhecer que a previdência privada, a qual por força do próprio texto constitucional (art. 202) é um regime facultativo, não está compreendida no conceito de seguro social, ainda que em alguns países como, por exemplo, no Chile, seja um regime obrigatório.

Embora não se possa afirmar que é um seguro em sentido estrito (pois, como veremos nos capítulos a seguir, haverá fases e modalidades de planos em que não se identificarão os elementos necessários para qualificá-la como tal), pode-se asseverar que é um mecanismo de prevenção contra riscos, razões pelas quais se aproxima dos contratos de seguros.

\subsection{Seguros de danos e seguros de pessoas}

No âmbito dos seguros privados existe uma subdivisão entre seguros de danos e seguros de pessoas, classificação esta abrigada pelo Código Civil de $2002^{233}$.

Para alguns autores, a principal diferença entre eles diria respeito ao caráter indenitário, que a princípio ocorreria no seguro de danos e não no de pessoas ${ }^{234}$, embora

nacional; d) aprovar os limites de operações das Sociedades Seguradoras, de conformidade com o critério fixado pelo CNSP; e) examinar e aprovar as condições de coberturas especiais, bem como fixar as taxas aplicáveis; f) autorizar a movimentação e liberação dos bens e valôres obrigatòriamente inscritos em garantia das reservas técnicas e do capital vinculado; g) fiscalizar a execução das normas gerais de contabilidade e estatística fixadas pelo CNSP para as Sociedades Seguradoras; h) fiscalizar as operações das Sociedades Seguradoras, inclusive o exato cumprimento dêste Decreto-lei, de outras leis pertinentes, disposições regulamentares em geral, resoluções do CNSP e aplicar as penalidades cabíveis; i) proceder à liquidação das Sociedades Seguradoras que tiverem cassada a autorização para funcionar no País; j) organizar seus serviços, elaborar e executar seu orçamento; k) fiscalizar as operações das entidades autorreguladoras do mercado de corretagem, inclusive o exato cumprimento deste Decreto-Lei, de outras leis pertinentes, de disposições regulamentares em geral e de resoluções do Conselho Nacional de Seguros Privados (CNSP), e aplicar as penalidades cabíveis; e 1) celebrar convênios para a execução dos serviços de sua competência em qualquer parte do território nacional, observadas as normas da legislação em vigor."

${ }^{233}$ No Capítulo XV do CC02, a Seção II (art. 778 a 788) trata dos seguros de danos, e a Seção III (art. 789 a 802) dispõe sobre seguro de pessoas.

${ }^{234}$ V.g. Pedro Alvim (op. cit, pp. 76 e 77), Vera Helena de Mello Franco (Contratos, op. cit., p. 345). 
outra corrente doutrinária defenda que esse caráter está presente em ambos, ainda que guardando características próprias em cada um ${ }^{235}$.

Os seguros de danos caracterizam-se por garantir o ressarcimento por uma perda material ou patrimonial, ocorrida por conta da materialização de um risco predeterminado.

Pelo fato de haver esse caráter de ressarcimento, tais seguros têm algumas regras específicas, tais como (i) a limitação do valor da indenização ao do interesse submetido ao risco $^{236}$, (ii) a vedação da contratação de múltiplos seguros para o mesmo risco ${ }^{237}$ (exceto quando se tratar de cosseguro) e (iii) a possibilidade de haver sub-rogação ${ }^{238}$ da seguradora no lugar do segurado, para evitar enriquecimento sem causa deste último.

De outra ponta, há os seguros de pessoas, cujo objetivo é oferecer cobertura contra riscos que possam afetar a existência, a integridade corporal ou a saúde do segurado.

\section{Como esclarece Vera Helena de Mello Franco ${ }^{239}$ :}

A finalidade aqui [seguros de pessoas] não é a de reparar um dano ou um prejuízo patrimonial, mas sim de previdência. A saber: resguardar o segurado contra eventos que possam criar um ônus a si ou a um terceiro, eventualmente prejudicado com sua morte. Pode ainda ter uma finalidade de poupança, garantindo o seu futuro ou o de um terceiro (v.g. seguro de sobrevida).

O jurista português Moitinho de Almeida ${ }^{240}$, em consonância com este entendimento, ensina:

\footnotetext{
${ }^{235}$ Tzirulnik, Cavalcanti e Pimentel, op. cit., p. 151; Tullio Ascarelli, op. cit., p. 328.

${ }^{236}$ Como ensina Pedro Alvim: "Ninguém pode lucrar com o evento danoso ou tirar proveito de um sinistro. Deverá receber em dinheiro ou espécie aquilo que perdeu. O pagamento a mais pode servir de estímulo à fraude ou à especulação, por isso a legislação de todos os povos fulmina de nulidade o seguro de valor superior ao bem." (op. cit, p. 77) Neste sentido é o art. 778 do CC02: "Nos seguros de dano, a garantia prometida não pode ultrapassar o valor do interesse segurado no momento da conclusão do contrato, sob pena do disposto no art. 766, e sem prejuízo da ação penal que no caso couber."

${ }^{237}$ Conforme o art. 782 do CC02.

${ }^{238}$ Consoante a doutrina de Yvonne Lambert-Faivre e Laurent Leveneur: Sub-rogação é a substituição que se opera a partir de um credor para outro, no momento do pagamento; por seus efeitos, o credor adquire o subrogado, que é objeto de pagamento, com todos os acessórios, para que ele nunca mais possa reclamar do que ele não pagou, porque a sub-rogação não é uma operação especulativa. (tradução livre) "La subrogation est la substitution qui s' opère d'un créancier à un autre à l'occasion d'un paiement; par ses effets, le créancier subrogé acquiert la créance qui a fait l'objet du paiement avec tout ses accessoires mais en revanche, il ne peut jamais réclamer plus qu'il n'a payé, car la subrogation n'est jamais une opération spéculative." Droit des assurances, $13^{\mathrm{a}}$ ed. Paris: Dalloz, 2011, p. 450.

${ }^{239}$ Contratos. Op. cit., p. 345.
} 
A nosso ver, a autonomização da categoria dos seguros de pessoas, sujeita a um regime jurídico alheio ao dano efectivamente sofrido pelo segurado, é aconselhada por razões de ordem prática. Em primeiro lugar, a aplicação das normas que regulam o sobresseguro e os seguros múltiplos revela-se francamente inoportuna. Só em situações extremas se pode dizer que um seguro excede o valor dos possíveis danos, resultantes para o segurado de acidente ou doença, e qualquer redução feita seria arbitrária. A natureza fugidia e indeterminável dos danos pessoais é avessa à fixação de quaisquer limites.

Portanto, com as devidas ressalvas ${ }^{241}$, a previdência privada será abordada a partir do ponto de vista do seguro de pessoas, por ser uma operação relacionada com a sobrevivência do participante. Nela, não há limitação para o valor da indenização, já que a vida é um bem cuja importância não se pode mensurar objetivamente ${ }^{242}$. Como decorrência, também não há proibição para contratação de dois ou mais planos para a mesma pessoa. E, além disso, não se aplica a possibilidade de sub-rogação da seguradora no lugar do participante, segurado ou do beneficiário pois, assim como no seguro de pessoas, a indenização pode não corresponder à perda sofrida pelo participante, segurado ou beneficiário, razão pela qual aquele que recebeu a indenização pode cumular as ações que tiver contra o causador dos seus danos.

\subsubsection{Classificação dos seguros de pessoas}

Há diversas classificações do seguro de pessoas ${ }^{243}$, mas entendemos que a melhor aplicável aos objetivos deste trabalho é a que tem por base o risco ${ }^{244}$.

240 ALMEIDA, J. C. Moitinho de. O contrato de seguro no direito comparado. Lisboa: Livraria da Costa, 1971 , p. 304.

${ }^{241}$ Considerando que o propósito desta dissertação é comprovar se de fato a previdência privada é um seguro.

242 Como destaca Vera Helena de Mello Franco (Contratos. Op. cit., p. 345): “A soma no seguro de pessoas, ao contrário do que ocorre nos seguros de danos, é livremente estimada (art. 789 do CC/02), dado que não se pode mensurar, objetivamente, o valor de determinadas qualidades ou atributos pessoais. Tampouco é possível estabelecer o valor da vida humana. Por isso se diz um seguro de somas. Ele não necessita corresponder a um prejuízo efetivo do segurado e, como a prestação visada não tem caráter de indenização, não está submetido ao princípio indenitário.”

${ }^{243}$ Por exemplo: quanto à forma de contratação, os seguros podem ser individuais ou coletivos; quanto à relação entre quem celebra o contrato e o bem exposto ao risco, podem ser seguros por conta própria ou por conta de outrem; quanto à duração, podem ser temporários ou não temporários.

${ }^{244}$ Classificação adotada, por exemplo, por Donati e Putzolu (op. cit, p. 185), Lambert-Faivre e Leveneur (op. cit., pp. 756 e 757). 
Assim, os seguros de pessoas dividem-se em: (i) seguros por morte; (ii) seguros com cobertura por sobrevivência; e (iii) seguros mistos.

Os primeiros são aqueles em que a obrigação de indenizar da seguradora surge a partir do falecimento do segurado.

Sobre tais seguros, Ascarelli ${ }^{245}$ discorre:

O seguro para o caso de morte pode prender-se à indenização de despesas extraordinárias provocadas pela morte [funeral]; prende-se, entretanto, antes de mais nada, à indenização do lucro cessante e do benefício esperado, justamente porque a morte importa na impossibilidade de realizar (e poupar) os ganhos que, continuando a vida, poderiam ter sido auferidos (e poupados). É, pois, natural em cada um o desejo de evitar essa consequência de uma morte prematura e de ter a certeza de poder, de qualquer forma, realizar os lucros que uma vida mais longa teria permitido realizar e poupar.

Nos seguros por sobrevivência, por seu turno, é a sobrevida do segurado a determinado prazo (denominado período de diferimento) que faz surgir para a seguradora a obrigação de pagar a indenização ao próprio segurado.

Neste seguro, cobre-se a necessidade inerente à subsistência do segurado, a qual se manifesta em forma de dano emergente (os gastos vinculados à velhice) ou de lucro cessante (redução de capacidade de rendimento econômico do indivíduo) ${ }^{246}$.

A capacidade do homem de adquirir patrimônio e acumulá-lo é crescente até certa fase da vida, e decresce conforme se aproxima da velhice.

Como visto, hoje em dia a expectativa de vida do ser humano é muito maior que a de seus antepassados. Porém, à medida que se aproxima da terceira idade, muitas pessoas abandonam sua vida ativa - seja ou não por vontade própria, e têm de se preparar economicamente para o futuro, precavendo-se para que seus recursos financeiros durem mais do que sua vida remanescente, especialmente considerando o aumento com os gastos com saúde.

\footnotetext{
${ }^{245}$ Op. cit., p. 337.

${ }^{246}$ Conforme Tapia Hermida. (Manual. Op. cit., p. 252)
} 
Atendendo a essa demanda, no seguro de sobrevivência a seguradora, mediante o pagamento de um prêmio, compromete-se a prestar uma garantia de que pagará o capital segurado ou a renda contratada se o segurado chegar com vida em determinada data.

Por fim, nos seguros mistos há cobertura tanto para a morte quanto para a sobrevivência do segurado. Se o segurado falecer durante o período de diferimento, o beneficiário indicado recebe a indenização. Se ele sobreviver ao referido período, ele mesmo receberá o capital segurado.

\subsection{Elementos do contrato de seguro}

Os elementos do contrato de seguro são peças fundamentais para sua compreensão. Por meio da sua identificação será possível, no próximo capítulo, confirmar se estamos ou não diante de um contrato de seguro, quando analisarmos a reserva matemática dos planos de previdência privada objeto dessa dissertação.

Vários doutrinadores procuraram listar tais elementos e acabaram por quase sempre adotar a mesma linha. Alguns separam, outros unificam, mas afinal a realidade é una, ainda que vista por ângulos diversos ou designada por nomes diferentes.

Para Vera Helena de Mello Franco ${ }^{247}$ os elementos são o interesse, o risco, o prêmio, a garantia e a indenização. Para Ernesto Tzirulnik, Flávio de Queiroz Bezerra Cavalcanti e Ayrton Pimentel ${ }^{248}$ são a garantia, o interesse, o risco, o prêmio e a empresarialidade. Isaac Halperín ${ }^{249}$, por sua vez, entende que são o interesse segurável, o risco e o prêmio. Já para Clóvis Bevilaqua ${ }^{250}$ são o segurador, o segurado, o prêmio e o risco. Para Carlos José María Facal ${ }^{251}$ são o prêmio, a garantia e o risco. José Vasques ${ }^{252}$ defende que são a seguradora, o tomador do seguro, o prêmio, a garantia, o interesse e o

\footnotetext{
${ }^{247}$ Contratos, Op. Cit.

248 O contrato de seguro de acordo com o Novo Código Civil Brasileiro. São Paulo: Revista dos Tribunais, 2003.

${ }^{249}$ Seguros, exposición crítica de la ley 17418. Buenos Aires, 1972, pp. 46 e 536.

${ }^{250}$ Código Civil, Ed. 1952, v. 5, p. 192

${ }^{251}$ FACAL, Carlos José María. Op. cit.

${ }^{252}$ Op. cit.
} 
risco. Para Yvonne Lambert-Faivre e Laurent Leveneur ${ }^{253}$ os elementos jurídicos ${ }^{254}$ são o risco, o prêmio e o sinistro.

Nesta dissertação adotaremos os elementos jurídicos extraídos do próprio conceito de contrato de seguro do art. 757 do Código Civil, os quais destacamos a seguir: "Pelo contrato de seguro, o segurador se obriga, mediante o pagamento do prêmio, a garantir interesse legítimo do segurado, relativo a pessoa ou a coisa, contra riscos predeterminados." (n.g.)

Seriam eles, portanto: o segurador (empresarialidade), o prêmio, a garantia, o interesse legítimo e o risco. Consideraremos ainda, entretanto, um elemento não jurídico que, embora não esteja estampado no referido artigo, é a base da operação securitária: o mutualismo.

\subsubsection{Empresarialidade}

Nos primórdios da existência do contrato de seguro, entendia-se que qualquer pessoa podia se prestar a dar uma garantia, havendo poucas exigências com relação àquele que se relacionava com o segurado. Nas palavras de Pedro Alvim ${ }^{255}$ : “qualquer pessoa, desde que dispusesse de receita e inspirasse a confiança do segurado, podia assumir a posição de segurador."

Com o passar do tempo, verificou-se que o segurador individual carecia muitas vezes de condições técnicas e econômicas para viabilizar a operação securitária. Como ensina o mesmo autor ${ }^{256}$ :

[...] coube a Vivante o mérito de iniciar a luta contra o segurador individual, mostrando que se trata de uma atividade que não comporta as operações isoladas ou eventuais. Só a empresa de seguros, com suporte econômico e técnico e um trabalho permanente pode consolidar suas operações e oferecer garantia a seus segurados.

\footnotetext{
${ }^{253}$ Op. cit., p. 263 e ss.

${ }^{254}$ As autoras destacam, contudo, que do ponto de vista técnico o principal aspecto do contrato de seguro é a mutualidade. Op. cit., p. 40.

${ }^{255}$ Op. cit., p. 178.

${ }^{256}$ Op. cit, p. 179.
} 
No mesmo sentido é a lição de Menezes Cordeiro ${ }^{257}$ :

O contrato de seguro é, ele próprio, infletido pela celebração profissional. Como tem sido sublinhado, o contrato de seguro isolado seria uma espécie de aposta; quando concluído em união, por banda da seguradora, toma uma feição industrial proveitosa para todos.

E fazendo uso das palavras de Cesare Vivante ${ }^{258}$ :

O seguro não se pode considerar atualmente como um negócio isolado, como no século passado, quando os comerciantes assumiam quaisquer riscos em busca da boa sorte, sem se dedicarem a uma atividade sistemática de seguros (...) No comércio de seguros hoje exercido, atuam exclusiva e sistematicamente por grandes empresas comerciais, com uma série contínua de negócios homogêneos. (...) Esta base econômica influi na construção jurídica das empresas e do contrato de seguro.

A teoria da empresa de Vivante, escorada na ideia da essencialidade do elemento empresarial, procurou explicar o conceito unitário ${ }^{259}$ de seguro. Ascarelli ${ }^{260}$, sobre esse tema, afirma:

${ }^{257}$ Op. cit., p. 175.

${ }^{258}$ Il contrato di assicurazione. Milão: 1885, v. I, p. 76, apud TZIRULNIK, CAVACANTI e PIMENTEL (Op. cit., p. 38), tradução livre dos autores.

${ }^{259}$ A polêmica em torno do caráter unitário do contrato de seguro diz respeito à questão a respeito de se seria possível obter um conceito de seguro que abrangesse tanto o seguro de danos quanto o de pessoas. Em outras palavras, se haveria uma causa ou função econômico social comum a ambos. Para parte da doutrina (v.g. Moitinho de Almeida, Op. cit., p. 304), por conta das diferenças existentes entre os seguros de danos e de pessoas, haveria dois regimes aplicáveis, distintos entre si. Moitinho entende que, por questões de ordem prática, é melhor que haja a autonomização da categoria do seguro de pessoas. Outra parte da doutrina (Tzirulnik, Cavalcanti e Pimentel, por exemplo, Op. cit., p. 151) entende que, apesar de existirem características diferentes, não significa que existam dois regimes. Diante dessa polêmica, buscou-se unificar o conceito de seguro, por meio da construção de algumas teorias (segundo Vera Helena de Mello Franco, Contratos, op. cit., pp. 302 e ss.: i) teoria da necessidade eventual, segundo a qual em todo contrato de seguro existe uma necessidade eventual do segurado. A crítica que se faz a essa teoria é no sentido de que no seguro de danos haveria uma necessidade concreta, e no de pessoas a necessidade seria abstrata. Essa dualidade de necessidades poderia negar a própria existência da teoria. A importância dessa teoria acabou sendo outra: distinguir o jogo da aposta. ii) teoria da empresa, defendida por Vivante, segundo a qual a operação de seguros, por seu caráter mutualístico e por ser realizada em massa, exigiria uma atividade organizada. A crítica que se aponta é que de fato a empresa é um dos elementos (não técnicos) do contrato de seguro, mas esse elemento, por si só, não é capaz de lhe dar unidade. iii) nova teoria indenitária (denominação adotada por Vera Helena de Mello Franco): seria constituída por interesse, necessidade e dano. Segundo a teoria, o evento que provoca uma necessidade econômica causaria um dano, o que demonstraria que tanto a necessidade quanto o dano são coincidentes. A finalidade do seguro seria não ressarcir um dano concreto, mas, sim, atuar como forma de garantia contra uma expectativa de dano, uma eventual necessidade econômica. E é essa função que existe desde o início da relação do contrato de seguro - tanto no seguro de danos, quanto no de pessoas. iv) teoria da transferência do risco $\neg$ segundo essa teoria, a função do seguro tanto de danos quanto de pessoas, seria transferir um risco para a seguradora. A crítica apontada é que, a rigor, o risco não se "transfere" para a seguradora, ele é diluído, pulverizado por toda a mutualidade. Além 
A unidade do seguro está, segundo Vivante, no elemento que o próprio autor denomina técnico, da empresa, na circunstância de que, em todos os seus ramos, o seguro é exercido pelo segurador, sistematicamente, com fundamento no cálculo de probabilidades, de modo a, uma vez considerada a massa de contratos, desaparecer o caráter aleatório, próprio de cada contrato isoladamente considerado, e surgir a possibilidade de previsão da ocorrência dos sinistros, previsão baseada naquele cálculo.

Ou seja, Vivante defende a necessidade da operação securitária ser realizada por uma pessoa jurídica, legalmente autorizada para o seu desempenho, e que tenha condições técnicas e econômicas, com uma organização voltada para tanto.

Sua teoria, entretanto, foi refutada no que toca à justificativa para a teoria unitária do contrato de seguro "sob o argumento de que, embora essencial para a feição técnicoeconômica do contrato de seguro, a empresa não seria elemento básico do conceito jurídico, afastando-se pudesse ser a característica distintiva, básica e constante, apta a servir de base para o conceito unitário pretendido."261

Ascarelli conclui ${ }^{262}$ que a tese de Vivante indica a base técnica da indústria seguradora, mas não a caracterização jurídica do contrato.

Contudo, independentemente da serventia de sua teoria para o conceito unitário, há de se reconhecer a relevância do elemento empresarialidade para o contrato de seguro, ainda que parte da doutrina ${ }^{263}$ não assim a considere. Tanto é que o próprio ordenamento jurídico brasileiro acolheu esse elemento ${ }^{264}$.

dos itens apontados acima, Tzirulnik, Cavalcanti e Pimentel apontam uma quinta teoria, do interesse. Para os autores, o elemento que daria unidade ao contrato de seguro seria o interesse, adotado pelo CC02, o que, segundo os autores, teria representado uma importante inovação no direito do seguro.

260 Op. cit, p. 311.

${ }^{261}$ Vera Helena de Mello Franco. Contratos. Op. cit., p. 303.

262 Op. cit, p 315.

263 Antigono Donatti, Tratatto del Diritto de la Assicurazioni Private - volume secondo. Milano: Multa Pacis, 1954, pp. 40-41. (apud Luis Augusto Roux Azevedo, op. cit., p. 32)

${ }^{264}$ Note-se, contudo, que o substitutivo do CC16 elaborado por Fábio Konder Comparato originalmente não previa a empresarialidade como um elemento - tanto é que o parágrafo único do atual art. 757 tinha outro conteúdo. Nas palavras do jurista: "Na definição do art. I, estão contidos os quatro elementos fundamentais do contrato: o interesse, o risco, a garantia e o prêmio. (Substitutivo ao capítulo referente ao contrato de seguro no anteprojeto do Código Civil in Revista de Direito Mercantil, Industrial, Econômico Financeiro. Ano XI (Nova Série), no 5. São Paulo: Revista dos Tribunais, 1972, p. 147) 
Partiremos, portanto, do entendimento da empresarialidade como um elemento jurídico, essencial aos olhos do ordenamento jurídico brasileiro para a caracterização do contrato de seguro, sem desprezar, todavia, que do ponto de vista técnico e prático um seguro pode existir, mesmo que não operado por uma seguradora.

\subsubsection{Vantagens da empresarialidade para o seguro}

Dentre as vantagens da empresarialidade para a operação securitária estão a sistematização das atividades, a uniformização de procedimentos, a possibilidade de angariação de um grande número de negócios, a profissionalização e a especialização da atividade.

Menezes Cordeiro ${ }^{265}$, sobre esse tema, discorre: "O segurador deve ser um profissional - se quiser, uma empresa, que lida, em moldes científicos, com os grandes números."

\subsubsection{Empresarialidade no Brasil}

Não se praticou seguro individual no Brasil. Note-se, nesse sentido, que a primeira seguradora brasileira (Companhia de Seguros Boa Fé) já surgiu sob a forma empresarial.

Para Vera Helena de Mello Franco ${ }^{266}$, os seguros individuais não seriam propriamente seguros, mas sim uma mera transferência de riscos acessória a uma operação de crédito. Ou seja, consistiriam em uma espécie de mútuo cujo pagamento pelo mutuário se subordina à condição de que a empreitada seja bem sucedida. Nestes casos, não haveria mutualidade; o risco não seria pulverizado, mas sim transferido para a outra parte da operação.

${ }^{265}$ Op. cit., p. 471.

${ }^{266}$ Contratos. Op. cit. p. 287. 
E continua a mesma autora ${ }^{267}$ : “o seguro é uma operação realizada em massa. Inexiste possibilidade de uma operação de seguros isolada. Numa operação isolada, tem-se apenas um contrato de transferência de riscos, e não um contrato de seguros."

Em nosso país, por imposição do ordenamento jurídico, o seguro é uma atividade empresarial $^{268}$, como determina o art. $1^{\circ}$ do DL n ${ }^{\circ}$ 2.063/40: A exploração das operações de seguros privados será exercida no território nacional, por sociedades anônimas, mútuas e cooperativas, mediante prévia autorização do Governo Federal.

Posteriormente, o rol de instituições ficou mais reduzido com redação do art. 24 do DL 73/66: "Poderão operar em seguros privados apenas Sociedades Anônimas ou Cooperativas, devidamente autorizadas."

Corroborando com o dispositivo acima está o parágrafo único do art. 757 do CC02: "Somente pode ser parte, no contrato de seguro, como segurador, entidade para tal fim legalmente autorizada."

As sociedades mútuas, que foram admitidas em nosso ordenamento pelos artigos 1466 a 1468 do CC16, não são mais autorizadas a explorar atividades securitárias, como explica Silvio Venosa ${ }^{269}$ :

Originalmente, havia possibilidade de atuação das seguradoras de seguro mútuo (mutual corporations). Constituem-se de um grupo de pessoas que se dispõem a proteger determinado prejuízo, a fim de que sua repercussão se atenue pela dispersão dos valores vertidos em favor da coletividade restrita. Forma-se uma entidade de auxílio mútuo para a qual contribuem todos os integrantes em benefício dos sócios atingidos pelo infortúnio. Seus membros não são detentores de ações, mas titulares de apólices. (grifos do autor)

Tais sociedades não tiveram grande sucesso no Brasil já que, na opinião de $\operatorname{Venosa}^{270}$, "não havendo estímulo de participação nos resultados para seus dirigentes, esses diretores não se empenhavam com a disposição de empresários".

\footnotetext{
${ }^{267}$ Op. Cit, p. 291.

${ }^{268}$ Exceção à regra da empresarialidade é o caso do Lloyds, na Inglaterra, que surgiu por volta de $1700 \mathrm{e}$ reunia pessoas ligadas às navegações (proprietários de navios, fretadores, corretores entre outros). E, posteriormente, transformou-se em uma espécie de "bolsa de seguradores" subordinada a um comitê central. ${ }^{269}$ Op. cit. p. 425.
} 
Quando o DL 73/66 proibiu a constituição de novas sociedades mútuas, facultou, contudo, a possibilidade de cooperativas atuarem com relação a seguros agrícolas, de saúde e acidentes de trabalho ${ }^{271}$.

Assim, a atividade securitária ficou restrita às sociedades anônimas.

As sociedades anônimas, pela sua estrutura, possibilitaram o crescimento econômico do século XIX. São mecanismos de arrecadação e fornecimento de recursos, sem os quais o desenvolvimento econômico e industrial (que exigiu investimentos de vultosos capitais e apelo permanente ao crédito) não teria ocorrido da mesma forma. ${ }^{272}$

Conforme Tullio Ascarelli ${ }^{273}$ :

A sociedade anônima apresentou-se como o instrumento típico da grande empresa capitalística e, com efeito, surgiu e se desenvolveu com esse sistema econômico e em relação às suas exigências; meio para a mobilização das economias de vastas camadas da população e para a conseguinte difusão da inversão, instrumento jurídico para a realização dos projetos de uma economia que se ia renovando de uma maneira radical.

Na mesma esteira é a doutrina de Vera Helena de Mello Franco e Rachel Sztajn $^{274}$ :

A sociedade anônima, dotada de capacidade ilimitada para atrair recursos financeiros, com a correlata possibilidade de limitar e dispersar os riscos decorrentes do exercício do empreendimento, foi o modelo jurídico

${ }^{270}$ VENOSA, Silvio. Op. cit. p. 425.

${ }^{271}$ Os seguros de acidentes de trabalho, no Brasil, acabaram por ser absorvidos pelo Estado, conforme os artigos $1^{\circ}$ e $2^{\circ}$ do Decreto $\mathrm{n}^{\circ}$ 61.784/67: Art. $1^{\circ} \mathrm{O}$ seguro de acidentes do trabalho é obrigatório e está integrado na previdência social, nos têrmos da Lei $\mathrm{n}^{\circ}$ 5.316, de 14 de setembro de 1967. Art. $2^{\circ} \mathrm{O}$ seguro de acidentes do trabalho será realizado pela emprêsa no Instituto Nacional de Previdência Social (INPS), na forma dêste regulamento, em favor: I - dos empregados em geral; II - dos trabalhadores avulsos; III - dos presidiários que exerçam atividade remunerada.

${ }_{272}$ Nesse sentido, vide a observação sobre a importância ocupada pelas sociedades anônimas na economia do século XIX: “(...) A sociedade por ações se havia convertido no instrumento predileto do alto capitalismo, na máquina preferida do capitalismo, porque se o capitalismo necessita da acumulação de enormes capitais para as grandes empresas do século XIX (de ferrovias, seguros, navegação, etc.), que melhor instrumento que este, que eu chamaria máquina colheitadeira de capitais, que é a sociedade anônima. (...)” GARRIGUES, Joaquín. Problemas Atuais das Sociedades Anônimas. Porto Alegre: Sergio Antonio Fabris, 1982, p. 13.

${ }^{273}$ Op. cit. p. 457.

${ }^{274}$ Direito Empresarial II - Sociedade anônima e mercado de valores mobiliários. São Paulo: Revista dos Tribunais, 2009, pp. 36 e 37. 
societário adequado para prover a essa necessidade de grandes volumes de capitais.

Tais sociedades permitem a obtenção de recursos imprescindíveis para o desenvolvimento de uma empresa, mediante a confluência de pequenas poupanças que somam recursos indispensáveis para a realização de determinadas atividades.

\author{
Como explica Oscar Barreto Filho ${ }^{275}$ :
}

Realmente, a sociedade anônima possibilitou ampla democratização das relações de participação na produção, sem distinção de classes sociais, ao aumentar extraordinariamente o número de pequenos capitalistas, possuidores de ações e de obrigações. Permitindo a repartição dos benefícios e dos lucros das empresas entre um número considerável de indivíduos, a sociedade por ações constitui o traço de união entre a pequena propriedade e a grande indústria.

Portanto, dada a complexidade da atividade securitária e os requisitos legais para o seu exercício (infra, item 3.8.1.4), tais como a exigência de capital mínimo e constituição de reservas técnicas, faz-se necessária uma estrutura organizacional economicamente robusta - o que, no caso das sociedades anônimas é facilitado pela atração de capitais inerente a esse tipo societário.

Mas a escolha pelas sociedades anônimas não se restringe à questão do capital ${ }^{276}$. Tais sociedades apresentam outras características que interessam aos propósitos da atividade securitária como, por exemplo, a publicidade dos atos constitutivos, assembleias gerais e demonstrações financeiras; a responsabilidade dos acionistas ser limitada ao montante das ações $\operatorname{subscritas}^{277}$; a impessoalidade da organização ${ }^{278}$; e a estrutura complexa com órgãos ${ }^{279} \mathrm{e}$ atribuições específicas.

\footnotetext{
${ }^{275}$ Regime Jurídico das Sociedades de Investimento. São Paulo: Max Limonad, 1956, pp. 35-36.

276 Nesta esteira é a crítica de Carlo Felice Giampaolino (op. cit, p. 44): "Se a difusão da participação acionária for entendida como justificativa para catação de maior quantidade de capital, esta função pode ser excluída [das companhias de seguros] porque, dados os fluxos de caixa das seguradoras, não parece que o tamanho do capital de risco possa influenciar no desempenho das suas obrigações." (Tradução livre) "Se si intente la diffusione della partecipazione come possibilità di raccolta di un capitale di maggiore ammontare, questa funzione può essere esclusa perché, visti i flussi finanziari dell'impresa di assicurazione, non sembra che la largheza della raccolta del capitale di rischio possa influenziare l'adempimento da parte dell'impresa delle proprie obbligazioni."

${ }^{277}$ Art. $1^{\circ}$ da lei $n^{\circ} 6404 / 76$.

${ }^{278}$ Sobre este tema, Vera Helena de Mello Franco e Rachel Sztajn destacam que a sociedade anônima "não se reduz ao conjunto de acionistas, mas é portadora de interesses próprios", razão pela qual a base de sua constituição é o estatuto, e não o contrato [nota das autoras: Rachel Sztajn discorda desse entendimento,
} 
Daí se justifica o porquê de a legislação brasileira $^{280}$ exigir que a atividade seguradora seja empresarial e, em especial, prestada por sociedade anônima.

Carlo Felice Giampaolino ${ }^{281}$ faz uma analogia entre as seguradoras e os bancos no que toca à exigência da forma como sociedade anônima (que na Itália é da mesma forma que no Brasil):

Para as seguradoras entende-se que o negócio de seguros deve ser realizado apenas por aqueles indivíduos que são capazes de garantir o exercício eficiente da sua atividade, isto é, aqueles que dão expectativa segura da realização dos negócios inerentes à atividade seguradora. (Tradução livre)

O mesmo autor ${ }^{282}$ defende que a escolha do modelo de sociedade anônima para as seguradoras tem por objetivo a conservação da autonomia de gestão e do equilíbrio financeiro frente o eventual comportamento abusivo de algum sócio, e prevenir o risco de que a atividade securitária sirva como instrumento de arrecadação de recursos destinados a fins não securitários, no interesse do sócio controlador.

\subsubsection{Objeto social específico das seguradoras}

A seguradora deve atender a uma disciplina jurídica específica. O poder público estabelece limitações para o seu funcionamento, tal como a do art. 73 do DL 73/66: “As Sociedades Seguradoras não poderão explorar qualquer outro ramo de comércio ou indústria."

afirmando existir contrato e que o estatuto estaria reservado à disciplina da organização da imputação], o qual seria "instrumento hábil a regular interesses gerais e abstratos, quais sejam aqueles da sociedade, considerada em si mesma, tendo em vista o seu perfil institucional e corporativo". (op. cit, pp. 88-89)

${ }^{279}$ Assembleias gerais (ordinária e extraordinária), especiais (de acionistas preferenciais, de debenturistas e de titulares de partes beneficiárias), conselho de administração diretoria e conselho fiscal.

${ }^{280}$ Isso não ocorre necessariamente em outros países. Na Espanha, por exemplo, os seguros podem ser operados por sociedades anônimas, mas também por mútuas, cooperativas ou entidades de Direito Público.

281 "Per le società di assicurazione si è affermato che l'attivitá assicurativa deve essere svolta solo da quei soggeti che siano in grado di garantire un efficiente esercizio della relativa attività, cioè da chi ha che diano sicuro affidamento circa il conseguimento delle finalità proprie dell'assicurazione". L'organizzazione societária nella disciplina dell'a attività assicurativa. Milão: Giuffrè, 1998. p. 41 e ss.

${ }^{282}$ Op. cit, pp. 22 e 23. 
Assim, seu objeto social é restrito, limitado às operações de seguro e atividades correlatas. Sobre esse tema, Menezes Cordeiro ${ }^{283}$ discorre: "quando se limita o objeto de uma pessoa coletiva, seja ela uma sociedade, uma associação ou qualquer outra, tem-se naturalmente em vista que a mesma não e movimente fora da competente área: para proteção dela própria e de terceiros."

\subsubsection{Prévia autorização para funcionamento e demais exigências}

Para operar, no Brasil, as seguradoras necessitam de prévia autorização da Susep $^{284}$. Em caso de atuação como seguradora de pessoa jurídica que não obtenha autorização da Susep para tal, o CNSP estabelece sanção de multa no valor igual à importância segurada ${ }^{285}$.

As seguradoras devem (i) preencher rigorosos requisitos de capacitação patrimonial, por meio da constituição das provisões técnicas necessárias estabelecidas nos normativos infralegais ${ }^{286}$, que variam conforme aos riscos que pretendem assumir e aos ramos em que irão operar; (ii) apresentar capital social mínimo ${ }^{287}$ e (iii) aplicar os recursos nos termos dos limites ditados pelo Conselho Monetário Nacional ${ }^{288}$.

Elas devem procurar manter a solvência, com o objetivo de garantir os interesses expostos a riscos predeterminados, e porque são administradoras de poupança coletiva.

Dada a relevância da operação, deve haver constante fiscalização do Estado com relação às bases atuariais da operação.

\footnotetext{
${ }^{283}$ Op. cit., p. 182.

${ }^{284}$ Nos termos dos artigos 24 e 36, "a" do DL 73/66, respectivamente: "Poderão operar em seguros privados apenas Sociedades Anônimas ou Cooperativas, devidamente autorizadas." "Compete à SUSEP, na qualidade de executora da política traçada pelo CNSP, como órgão fiscalizador da constituição, organização, funcionamento e operações das Sociedades Seguradoras: a) processar os pedidos de autorização, para constituição, organização, funcionamento, fusão, encampação, grupamento, transferência de contrôle acionário e reforma dos Estatutos das Sociedades Seguradoras, opinar sôbre os mesmos e encaminhá-los ao CNSP (...)."

${ }^{285}$ Nos termos do art. 17 da Resolução no $243 / 11$.

${ }^{286}$ Resolução CNSP n ${ }^{\circ}$ 280/13.

${ }^{287}$ Conforme lei 5627/70.

${ }^{288}$ Consoante os artigos 28 e 29 do DL 73/66: "A partir da vigência dêste Decreto-Lei, a aplicação das reservas técnicas das Sociedades Seguradoras será feita conforme as diretrizes do Conselho Monetário Nacional." "Os investimentos compulsórios das Sociedades Seguradoras obedecerão a critérios que garantam remuneração adequada, segurança e liquidez."
} 


\subsubsection{Mutualismo}

O mutualismo é um elemento que não está estampado explicitamente no art. 757 do $\mathrm{CC}$ e, portanto, não jurídico. Mas é inerente, fundamental e imprescindível à técnica securitária.

Optamos por tratar do tema logo após discorrer sobre as seguradoras pois, corroborando o entendimento de Vera Helena de Mello Franco ${ }^{289}$, entendemos que a empresarialidade realça o aspecto mutualístico do seguro: “[a empresarialidade] deixou como herança o realce ao aspecto mutualístico e a ideia de cobertura recíproca dentre patrimônios ameaçados pelos mesmos riscos, base de toda a operação securitária".

O mutualismo pode ser definido como:

Termo que define princípio fundamental que constitui a base de toda a operação do seguro, ou seja, é a formação de uma massa econômica a partir de pequenas contribuições de um grupo de pessoas com interesses comuns, com o objetivo de atender às eventuais necessidades de alguns componentes desse grupo. ${ }^{290}$

Para Vera Carvalho Pinto ${ }^{291}$ “o mutualismo foi a fórmula encontrada para o impasse existente na priorização entre os interesses pessoais ou os da coletividade, possibilitando, assim, a harmonização e coexistência de ambos em atingir o bem comum.”

Em outras palavras, o mutualismo consiste na técnica de repartição de riscos entre uma coletividade de indivíduos com interesses comuns, submetidos a riscos de certa forma homogêneos.

${ }^{289}$ Contratos. Op. cit., p. 303.

${ }^{290}$ DEL FIORI, Alexandre. Op. cit, p. 101.

${ }^{291}$ Fundamentação filosófica do princípio do mutualismo nos contratos de seguro. Dissertação (Doutorado em Direito) - Pontifícia Universidade Católica de São Paulo, São Paulo, 2010. Disponível em: < http://www.dominiopublico.gov.br/download/teste/arqs/cp139588.pdf>. Acesso em: 05/08/13, p. 78. 
A necessidade da existência de uma coletividade justifica-se pelo fundamento dos cálculos estatísticos, probabilísticos e atuariais que a seguradora realiza para garantir cobertura com relação aos objetos expostos ao risco.

\section{Como discorre Pontes de Miranda ${ }^{292}$ :}

Com a descoberta do cálculo de probabilidade, as empresas de seguro tomaram lugar relevante na vida econômica contemporânea. Operou-se a organização e conceberam-se os programas no sentido de se assumir a álea com a diminuição dos eventuais prejuízos. Com isso, ganharam os seguradores e ganharam os contraentes de seguro e os beneficiados, por haver firmeza nas promessas segurativas. O segurador conta com os cálculos e por bem dizer assume os riscos sem risco. À pluralidade de segurados como que se superpõe a homogeneidade dos valores segurados. A técnica, baseada na matemática, serviu à vida econômica, criando tranquiilidade onde o que existia era o temor: $o$ temor do contraente, que obtinha o seguro para temer negativamente, posto que ainda pudesse ocorrer a insolvência do segurador; o temor do segurador, que assumia o risco com o afastamento das razões para o temor do segurador, diminuiu o restante do temor do inadimplemento pelo segurador, que persistia na mente do contraente ou do beneficiado. (n.g.)

Portanto, pelo fato de o mutualismo pressupor uma operação coletiva (pois, do contrário, não seria possível pulverizar os riscos do contrato, não haveria cálculo probabilístico, e a operação consistiria em uma aposta), pode-se afirmar que a análise do contrato de seguro que tem por base tão somente a relação entre segurado e seguradora é míope ${ }^{293}$.

Neste sentido é a lição de Luis Augusto Roux Azevedo ${ }^{294}$ :

Analisar-se um contrato de seguro isoladamente não dá ideia do complexo de relações materiais, econômicas e até mesmo jurídicas que são exigidas para que aquele dado contrato possa ser negociado e traga ao segurado o resultado que espera da operação, qual seja o de prevenção dos efeitos negativos que um risco pode ter sobre si.

Na mesma esteira, Ascarelli ${ }^{295}$ afirma:

\footnotetext{
${ }^{292}$ Op. cit., p. 410.

${ }^{293}$ Mencionamos, contudo, que existem casos, embora menos frequentes, em que o contrato de seguro apoiase na unicidade. Ascarelli ilustra a situação com o exemplo de seguro para uma expedição científica polar, em que talvez não haja experiência ou dados objetivos, bem como não haveria uma massa de segurados para repartir o risco. (Op. cit., p. 312)

${ }^{294}$ Op. cit., p. 4.
} 
Com relação a segurador, a existência de um só contrato de seguro constituiria uma anormalidade, e, ainda, nesse caso, não poderia haver a benéfica função social que é própria do seguro; só mediante um grande número de contratos é que o segurador elimina o caráter aleatório de cada um deles tomado isoladamente, e pode, de modo efetivo, fazer frente ao risco; somente por esse meio tal risco se torna suportável pois, afinal, fica repartido por todos os segurados, cada um dos quais substitui, pelo pagamento de um prêmio certo, cujo ônus pode suportar a eventualidade de um dano que, ao invés, seria muito grave.

\section{E complementa Walter Polido ${ }^{296}$ :}

Não haveria seguro se apenas um ou meia dúzia de riscos fossem subscritos, uma vez que as apólices consideradas nesse universo não consubstanciariam a atividade seguradora em toda a sua acepção técnica e jurídica; estariam sim identificando algum outro tipo de relação negocial, tal como a aposta ou o jogo, mas não o seguro, cuja instituição exige volume substancial de riscos homogêneos, tecnicamente calculados e com prêmios representativos do custo real dos riscos assumidos pelo seu tomador. (Grifos do autor)

A necessidade da operação de seguros ser realizada em massa é, portanto, também um elemento essencial, porque ressalta o aspecto mutualístico do contrato.

Conforme a lição de Ovídio Baptista da Silva ${ }^{297}$ : "O seguro é um sistema de poupança ou de economia coletiva, impensável quando ajustado individualmente." (grifos do autor)

Os contratos de seguros, diferentemente dos negócios jurídicos bilaterais, tais como os contratos de compra e venda, locação, mútuo dentre outros, dependem de um número de contratos análogos para compor a reserva técnica, que é a base da operação securitária.

E Ovídio Baptista continua ${ }^{298}$ :

${ }^{295}$ Op. cit., pp. 311-312.

${ }^{296}$ Contrato de seguro: novos paradigmas. São Paulo: Roncarati, 2010, pp. 93-94.

${ }^{297}$ Natureza jurídica do "monte de previdência" in Anais do II Fórum de Direito do Seguro "José Sollero Filho”. São Paulo: IBDS e Manuais Técnicos de Seguros, 2002, p. 81.

${ }^{298}$ Op. cit., p. 82. 
A miopia da nossa formação individualista somente vê, no contrato de seguro privado ou social, a relação bilateral concluída entre cada segurado e a respectiva instituição, mas impede vê-lo em sua verdadeira essência de negócio jurídico complexo, pelo qual a comunidade forma o negócio jurídico de seguro, mediante a constituição do "fundo de previdência". Esse acervo econômico é constituído pela "poupança coletiva" da comunidade seguradora. (grifos do autor)

\subsubsection{Garantia}

Uma das principais modificações trazidas pelo $\mathrm{CC} 02 \mathrm{~cm}$ relação ao Código Civil anterior, do ponto de vista do Direito do seguro, foi o reconhecimento de que a principal prestação da seguradora para com o segurado é a garantia, e não a indenização.

Conforme a definição de Tzirulnik, Cavalcanti e Pimentel ${ }^{299}$ :

[a garantia] é o reconhecimento de que a prestação do segurador não se restringe ao pagamento de uma eventual indenização (ou capital), o que apenas se verifica no caso de sobrevir lesão ao interesse garantido em virtude da realização do risco predeterminado. Tal prestação consiste, antes de tudo, no fornecimento de garantias e é devida durante toda a vigência material do contrato.

Isso porque a indenização pode nem chegar a se materializar na maioria das vezes, sempre que não ocorrer o sinistro. Todavia, desde o momento da celebração do contrato, a seguradora obriga-se a prestar uma garantia ao segurado, representada pela garantia e tranquilidade outorgada desde logo, pela contratação do seguro ${ }^{300}$.

É assim que enfatiza Vera Helena de Mello Franco ${ }^{301}$ :

A obrigação da seguradora surge antes do sinistro, e não com ele. A indenização, deste ponto de vista, é uma obrigação secundária, eventual e condicional, que pode ou não ocorrer. A garantia é uma obrigação constante, que tem início com a conclusão do contrato e perdura por todo o período coberto.

\footnotetext{
${ }^{299}$ Op. cit., p. 30

${ }^{300}$ POLIDO, Walter. Op. cit., p. 132.

${ }^{301}$ Contratos. Op. cit., p. 327.
} 
Segundo a doutrina de Comparato ${ }^{302}$, além das clássicas obrigações de meio e de resultado, haveria ainda um terceiro tipo a ser considerado, que seria a de garantia, cujo exemplo dado pelo doutrinador ilustra situação semelhante à da seguradora. Referindo-se a um caso hipotético em que Tício, ameaçado de morte por Caio, decide contratar um guarda-costas, Comparato ${ }^{303}$ afirma:

Pode mesmo suceder que o guarda-costas não tenha nunca oportunidade de se haver com Caio, ou seus sicários, ou ainda que Caio desista de seus malignos intentos devido à proteção armada doravante dispensada a Tício. Em qualquer hipótese, o guarda-costas terá cumprido fielmente a sua obrigação, pelo simples fato de assumi-la, fazendo jus à remuneração prometida. Neste terceiro tipo de obrigação [de garantia], portanto, a prestação não consiste numa simples atividade diligente e honesta do devedor em vista de um resultado, nem muito menos na efetiva produção de um resultado determinado. Se isto fosse exigido, o guarda-costas de Tício não teria direito a remuneração alguma, caso não tivesse de intervir contra Caio.

Foi o reconhecimento da garantia como elemento do contrato de seguro que afastou sua definição como um contrato aleatório ${ }^{304}$. Não se pode falar em alea, do ponto de vista da perspectiva do seguro, pois o risco de seguro não é mera sorte; é um dado objetivo, avaliado por meio de cálculos estatísticos e atuariais que garantem as bases da operação $^{305}$.

${ }^{302}$ Obrigações de meios, de resultado e de garantia. In Ensaio e pareceres de Direito Empresarial. Rio de Janeiro: Forense, 1978.

${ }^{303}$ Idem, p. 537.

${ }^{304}$ A classificação do contrato de seguro como comutativo, contudo, não é unânime. Para o argentino Rubén Stiglitz (Derecho de seguros. $4^{\mathrm{a}}$ ed. Tomo I. Buenos Aires: La Ley, 2004, p. 169, apud Walter Polido, op. cit, p. 130) haveria três elementos que configurariam a aleatoriedade do contrato de seguro: (i) a álea estar condicionada a um evento incerto; (ii) esse acontecimento dever ser enunciado no negócio jurídico celebrado e (iii) da verificação desse acontecimento resultar a existência ou inexistência de uma prestação pela outra parte contratante. Para Ricardo Bechara, o seguro é aleatório porque "o elemento considerável para qualificar a natureza jurídica de um contrato aleatório, distinguindo-o de um contrato comutativo, está na equivalência entre as prestações, eis que, enquanto os contratos tipicamente comutativos são timbrados pela equivalência real das prestações, nos contratos tipicamente aleatórios essa equivalência em regra não existe, justo em razão do risco que o caracteriza como seu elemento nuclear, razão pela qual ouso divergir do entendimento de que o fato de o segurador garantir o risco de que se ocupa o contrato seria o quantun satis para qualificá-lo como comutativo. O simples fato de o risco ser elemento essencial para a existência do contrato de seguro o afasta de qualquer natureza comutativa, até em função da mutualidade e dos cálculos de probabilidades que o regem, chamando para si a estatística e a ciência atuarial para orientarem a sua operação, dispensadas nos contratos comutativos." Contrato de seguro. aleatório ou comutativo? Disponível em < www.oabsp.org.br/comissoes2010/direito-securitario/artigos/../download>, acesso em 12/12/12.

${ }^{305}$ Neste sentido corroboram Vera Helena de Mello Franco (Lições de direito securitário: seguros terrestres privados. São Paulo: Maltese, 1993, p. 17), e Ernesto Tzirulnik e outros (O contrato de seguro, op. cit., p. $31)$. 
Tanto é que, desde o início da existência do contrato de seguro, a seguradora já deve observar uma série de deveres, tais como o da constituição de reservas, eventual contratação de resseguros, dentre outras medidas que assegurem, em caso de ocorrência do sinistro, a sua solvência e o cumprimento do dever de indenizar ${ }^{306}$.

Assim, sem entrar na polêmica a respeito da comutatividade ou aleatoriedade do contrato de seguro, a qual escapa ao objeto dessa dissertação, pode-se concluir que houve de fato uma mudança na visão do legislador com relação ao que se entende pela obrigação da seguradora, de modo que a garantia sobrepõe-se, em nosso ordenamento, ao dever de indenizar, o qual é entendido como uma obrigação secundária.

\subsubsection{Interesse}

A palavra interesse, de acordo com sua própria etimologia (inter esse $e^{307}$ ) significa "estar entre", indicando relação entre uma pessoa e um bem (inclusive um "bem da vida"). No âmbito do seguro, o interesse representa uma relação lícita, de conteúdo econômico ${ }^{308}$, entre o tomador do seguro e o bem exposto ao risco.

Trata-se de elemento que não havia sido acolhido pela definição de seguro do CC16 (art. 1432). Na opinião de Tzirulnik, Cavalcanti e Pimentel ${ }^{309}$, "normas como a do Código de 1916 (art. 1432) levavam os autores a aludir a seguro de pessoa e seguro de coisa, como se o contrato pudesse ser destinado à garantia da própria pessoa e da própria coisa e não do "interesse legítimo do segurado relativo $a$."

\footnotetext{
${ }^{306}$ Em contraposição a esse entendimento, Pontes de Miranda entende que "não se pode dizer que a prestação do segurador consista na preparação dos meios necessários a adimpli-la. (...) Nem, tampouco, afirmar-se que a prestação, no contrato de seguro, se identifica com a promessa de fazê-la." (op. cit, p. 425)

307 Fonte: Online Etymology Dictionary, Disponível em $<\mathrm{http}: / /$ www.etymonline.com/index.php?allowed_in_frame $=0 \&$ search $=$ interest $\&$ searchmode=none $>$, acesso em $02 / 03 / 14$.

${ }^{308} \mathrm{O}$ interesse, para fins do seguro, não pode ser meramente sentimental ou emocional, com a devida ressalva para o seguro de pessoas, em que algumas vezes não é tão evidente esse conteúdo econômico como no seguro de danos.

${ }^{309}$ Op. cit, p. 32
} 
Os mesmos doutrinadores ${ }^{310}$ definiram o interesse como:

[...] a posição juridicamente relevante de um sujeito de direito para com um bem da vida, de modo que a legitimidade é acostada para relevar a importância de que a pertinência entre o sujeito e o bem da vida seja de ordem a fazer com que aquele queira sua preservação, não desdenhe o status quo e não queria, nem lhe seja vantajosa, a realização do risco garantido. A garantia é o objeto imediato do seguro, e o interesse o objeto da garantia, portanto objeto mediato do contrato, requisito de validade do mesmo.

Ou seja, para tais autores, a relação existente entre o sujeito o bem deve ser tão relevante que este tomador não deseje a materialização de tal risco.

Malcolm Clarke ${ }^{311}$ aponta três razões para justificar a exigência do interesse segurável no contrato de seguro. A primeira seria para não confundir esse tipo contratual com um jogo ou uma aposta. Segundo o autor, o seguro não se deve prestar a propósitos estranhos ao seu uso econômico ou social. A segunda razão seria para evitar a tentação e o risco moral $^{312}$. Para o doutrinador, as pessoas que têm um efetivo interesse segurável são menos suscetíveis a qualquer impulso de atentar contra o objeto segurado. No exemplo do autor, "Uma pessoa com um grande rombo na conta corrente e pequeno amor pelo vizinho poderia sentir-se tentada a contratar um seguro de incêndio sobre a casa dele, e então colocar fogo nela; e, de repente, contratar um seguro sobre a própria vida do vizinho, e colocar fogo na casa quando ele estivesse ali." ${ }^{\prime 313}$ (tradução livre). E a terceira razão seria afastar a tentação e respeitar o Estado de Direito, ou seja, evitar a contratação de seguro pelas pessoas para resolver seus problemas financeiros quando já estão com dificuldades, minimizando o risco de fraude.

Vera Helena de Mello Franco ${ }^{314}$, embasada na doutrina de Garrigues ${ }^{315}$, define as características do interesse: (i) lícito; (ii) de caráter econômico - o que significa que deve ser apto a uma valoração patrimonial (objetivamente estimado, como no caso dos seguros

\footnotetext{
${ }^{310}$ Idem, ibidem..

${ }^{311}$ Policies and perspectives of insurance Law in the twenty-first century. New York: Oxford University, 2005, p. 36.

312 Sobre o risco moral, ou moral hazard: ARNOTT, Richard; STIGLITZ, Joseph. Moral Hazard and Nonmarket Institutions: Dysfunctional Crowding Out of Peer Monitoring? American Economic Association, disponível em <http://www.jstor.org/stable/2006794.>, acesso em 22/08/13.

313 "A person with a large overdraft but little love for a neighbor might be tempted to insure the neighbor's house against fire and then burn it; and also perhaps insure his life and burn it while his neighbor is there."

${ }^{314}$ Contratos. Op. cit., p. 316.

${ }^{315}$ GARRIGUES, Joaquim. Contrato de seguro terrestre. Madri: Imprenta Aguirre, 1979.
} 
de danos, ou subjetivamente estimado, como nos seguros de pessoas); (iii) deve preceder o momento do contrato e estar na sua conclusão.

Se fosse possível a alguém assegurar-se contra um evento em cuja realização não tivesse um interesse contrário, o seguro não seria possível. pois o beneficiário se transformaria em um provocador de sinistros para lucrar com a indenização ${ }^{316}$. Esse é o espírito do art. 790 do CC02: "No seguro sobre a vida de outros, o proponente é obrigado a declarar, sob pena de falsidade, o seu interesse pela preservação da vida do segurado."

A existência do interesse faz depender a própria validade do contrato de seguro.

O conceito de interesse está ainda atrelado à existência de um risco. Ou seja, o interesse é a relação jurídica existente entre uma pessoa (segurado) com um bem (objeto segurado). Quando a relação entre tomador e objeto segurado encontra-se ameaçada por um risco, torna-se um interesse segurável.

Conforme a doutrina de Medina ${ }^{317}$ :

O interesse é segurável no momento prévio à celebração do contrato de seguro, tornando-se interesse segurado quando se concretizou o acordo de vontades, requisito para a procedência do pagamento do seguro. $\mathrm{O}$ interesse segurável condiciona a aptidão do segurando para a celebração de contratos de seguros. $\mathrm{O}$ interesse segurado condiciona a possibilidade de fazer efetiva a cobrança do seguro.

O interesse possui, portanto, uma dimensão subjetiva, ou seja, que não interesse ao tomador a ocorrência do sinistro.

Possui, em contraste, também uma dimensão objetiva - o bem sobre o qual ele se assenta deve satisfazer determinada necessidade de natureza econômica do titular.

Como descrevem Tzirulnik, Cavalcanti e Pimentel ${ }^{318}$ :

\footnotetext{
${ }^{316}$ Conforme Tullio Ascarelli, op. cit., p. 307.

${ }^{317}$ MAGALLANES, Pablo Medina. Anais do III Fórum de Direito do Seguro José Sollero Filho. São Paulo: Manuais Técnicos de Seguros, IBDS, 2003. p. 382.

${ }^{318}$ TZIRULNIK, Ernesto. Regulação de Sinistro, São Paulo: Max Limonad, 2001, p. 62 e ss.
} 
[...] é justamente essa natureza ressarcitória ou indenizatória que vai dar base ao chamado 'princípio indenizatório', segundo o qual não só o segurado não pode lucrar com a realização do risco que lesiona seu interesse, como também há de ser, nos limites pactuados, recolocado no estado em que se encontrava anteriormente à verificação do sinistro.

Vale lembrar, como destacamos no item 3.7.1 (supra), que a tal natureza ressarcitória não tem o mesmo caráter para o seguro de pessoas e de danos. $\mathrm{O}$ reconhecimento do interesse como elemento do contrato de seguro foi fundamental para a viabilidade do contrato de seguro sobre a vida de outrem ${ }^{319}$, o que se observou pela primeira vez no Gambling Act de $1774^{320}$.

\subsubsection{Prêmio}

O prêmio é a prestação que corresponde ao tomador do seguro em contraprestação à garantia que lhe é prestada pela seguradora. É o preço (montante em dinheiro) que se paga para ter direito à cobertura do seguro.

Para Pontes de Miranda 321 “é a prestação do contraente que quer o segurador".

Seu valor é estimado conforme o risco assumido e de tal modo que por meio do mutualismo, seja possível constituir uma provisão capaz de fazer frente ao pagamento dos sinistros produzidos com relação a uma determinada massa de indivíduos.

\footnotetext{
${ }^{319}$ No seguro sobre a vida de outrem, além da exigência de interesse, é possível requisitar a existência de consentimento. Este padrão é observado em países como Itália (Art. 1.919, $2^{\mathrm{a}}$ alínea, do Código Civil italiano: "L'assicurazione contratta per il caso di morte di um terzo non è valida se questi o il suo legale rappresentante non dà il consenso alla conclusione del contratto. Il consenso deve essere provato per iscritto.”), França (Legislação de 1930, art. 56 e ss.), Alemanha (Lei de 1908, §159º), Suíça (Lei de 1908, art. 74) e Estados Unidos (Jurisprudência norte-americana), o que, no entendimento de José Vasques (Op. cit. p. 133), também poderia ser considerado como uma forma de interesse, servindo para eliminar a especulação no seguro sobre a vida de terceiros. A respeito da exigência do consentimento para realização de seguro de vida sobre outrem, é o entendimento de Moitinho de Almeida: "Parece que nenhuma pessoa deve poder ser segura sem o respectivo consentimento. Trata-se de uma proteção individual, de um meio de defesa contra o votum mortis do beneficiário ou do tomador, que importa consagrar legislativamente. Não basta estabelecer-se que o beneficiário ou o tomador perde o direito à prestação prometida pelo segurador se voluntariamente der a morte ao segurado. Essa sanção não dispõe de efeitos preventivos quanto a agentes homicidas convencidos de escaparem à repressão penal. É necessário facultar-se aos indivíduos o meio de obviarem à celebração de seguros de que venham a beneficiar pessoas cujas pretensões se antolhem duvidosas." (Op. cit. p. 341)

${ }^{320}$ Como retrata Moitinho de Almeida: "Em 1774 foi promulgado o Gambling Act, que exigiu, nos seguros sobre a vida de terceiros, um interesse legítimo do estipulante na vida do segurado." (op. cit., p. 312)

${ }^{321}$ Op. cit., p. 444.
} 
Sem o prêmio não é possível compor o fundo comum necessário à cobertura securitária. Como o seguro é um contrato celebrado em massa, só se viabilizar se houver o respectivo recebimento dos prêmios, de modo que nem mesmo a obrigação do pagamento do prêmio deve ser vista individualmente.

Nessa esteira é a lição de Vera Helena de Mello Franco ${ }^{322}$ :

[...] em matéria securitária, o contrato não pode ser visto isoladamente, pois a exploração em massa do contrato é o que permite fracionar, pulverizar o risco, disseminando-o pelo interior da mutualidade. Por isso é que o prêmio pago e a garantia devem ser considerados perante o conjunto das prestações da seguradora e do segurado, e não em relação a cada contrato isoladamente. Deste ponto de vista, se o segurado não paga, rompe-se todo o equilíbrio da mutualidade, prejudicando os demais.

O valor do prêmio varia conforme a probabilidade de ocorrência do risco - quanto maior o risco, maior também será o valor do prêmio, e vice-versa.

\subsubsection{Risco}

O risco também é elemento essencial da operação securitária, pois não faria sentido contratar um seguro contra um bem que não estivesse exposto a algum tipo de perigo. Faltaria causa ao negócio, uma vez que a prestação da seguradora seria inexistente ${ }^{323}$.

Neste sentido é a doutrina de António Menezes Cordeiro ${ }^{324}$ :

Uma definição do contrato de seguro que dispensasse o risco seria, formalmente, inatacável: o 'segurado' obrigar-se-ia, contra um 'prémio', a realizar, a favor do beneficiário, uma prestação convencionada, no caso de ocorrer determinado evento aleatório. Mas tal contrato, a ser juridicamente viável, redundaria numa simples aposta.

${ }^{322}$ Contratos, PP. 322 e 323.

${ }^{323}$ Fernando Sanchez Calero entende que o risco é um elemento tão importante, que o contrato em que ele falte é nulo, por não faz sentido contratar seguro sobre um bem que não está exposto a algum tipo de "perigo".

${ }^{324}$ Op. cit., p. 487. 
Tzirulnik, Cavalcanti e Pimentel ${ }^{325}$ definem o risco como "a possibilidade de ocorrência de um evento predeterminado capaz de lesar o interesse garantido.”

Para Menezes Cordeiro ${ }^{326}$, "o risco exprimiria a vertente negativa da álea: a do perigo de um mal. Risco pode, deste modo, ser definido como a probabilidade de diminuição, numa situação previamente considerada."

Por fim, para José Luis Maestro Martinez ${ }^{327}$ o risco é:

[...] a Possibilidade de que, por azar, ocorra um evento que acarrete o pagamento da prestação prevista no contrato. Esta prestação pode consistir no pagamento de uma indenização (nos seguros de danos) ou de um capital ou renda, inclusive a prestação de um serviço (seguros de pessoas). (tradução livre)

$\mathrm{O}$ risco relaciona-se com o sinistro à medida que o primeiro é o "evento futuro e incerto cuja materialização constitui o sinistro". ${ }^{328}$ Traz contido em si um sentido de potencialidade, ao passo que o sinistro é a materialização do dano, sendo o primeiro a potência e o segundo, o ato ${ }^{329}$.

Por ser um pressuposto do contrato de seguro, o risco deve estar presente em todos os momentos da sua execução ${ }^{330}$.

Ele serve de parâmetro para o cálculo da taxa do prêmio pela seguradora, por meio de cálculos estatísticos e atuariais: quanto maior for o risco, maior será o prêmio, e vice-versa.

\footnotetext{
${ }^{325}$ Op. cit., p. 36.

${ }^{326}$ Op. cit., p 485.

${ }^{327}$ [...] la posibilidad de que por azar se produzca un evento que dé lugar al pago de la prestación prevista en el contrato. Esta prestación puede consistir en el pago de una indemnización (seguros de daños) o de un capital o renta, o incluso en la prestación de un servicio (seguros de personas). Nociones generales sobre el contrato de seguro in Previsión y seguro, no 35. Madrid, Abril, 1994, p. 36.

${ }^{328}$ VASQUES, José. Op. Cit., p. 127.

329 Definição de Antonio Carlos Otoni Soares. Fundamento jurídico do contrato de seguro. São Paulo: Manuais Técnicos de Seguros, 1975, p. 92.

${ }^{330}$ Acompanhando este entendimento é o art. 773 do CC02: "O segurador que, ao tempo do contrato, sabe estar passado o risco de que o segurado se pretende cobrir, e, não obstante, expede a apólice, pagará em dobro o prêmio estipulado."
} 
Suas principais características são:

a) Incerteza $a^{331}$, a qual pode ser absoluta ${ }^{332}$ ou relativa $^{333}$.

b) Possibilidade. Deve ser possível de ocorrer, não sendo viável a cobertura securitária para fatos impossíveis de acontecer ${ }^{334}$. A intensidade do risco aumenta conforme sua possibilidade de ocorrência é maior ou menor.

c) Concretude. O risco deve ser passível de ser analisado e valorado pela seguradora, do ponto de vista qualitativo e quantitativo, com a aplicação de critérios objetivos, baseados na experiência ou em cálculos atuariais ou estatísticos da seguradora.

d) Licitude. Deve ser alinhado com o ordenamento jurídico, não podendo ser contrário à moral, em prejuízo de terceiros, contra os bons costumes ou contra a ordem pública ${ }^{335}$.

e) Involuntariedade. Deve ser alheio à vontade do segurado ${ }^{336}$ de produzi-lo, embora possa ter sido causado pela vontade de um terceiro, hipótese em que a seguradora, no caso do seguro de danos, reserva-se o direito de sub-rogar-se no direito daquele que foi lesado contra o causador do dano.

f) Ter conteúdo econômico. A ocorrência do risco deve produzir uma necessidade econômica que possa ser satisfeita com a indenização

${ }^{331}$ Para Pedro Alvim (op. cit., p. 218) a incerteza é um estado de espírito, uma noção abstrata que não participa da materialidade do evento. "Traduz nossa incapacidade de afirmação. É a dúvida oriunda do desconhecimento ou do conhecimento incompleto das coisas".

${ }^{332}$ Um evento ocorrer ou não ocorrer como, por exemplo, o roubo de um veículo. Nesse caso o contrato de seguro se traduz em uma obrigação condicional (submetido a uma condição suspensiva) com relação ao dever de indenizar da seguradora.

${ }^{333}$ Quando a incerteza diz respeito a quando o evento ocorrerá, que é o que ocorre, por exemplo, com o seguro de vida. Nessa hipótese a seguradora contrai uma obrigação a termo.

${ }^{334} \mathrm{O}$ próprio $\mathrm{CC} 02$, no art. 773 , estabeleceu: "O segurador que, ao tempo do contrato, sabe estar passado o risco de que o segurado se pretende cobrir, e, não obstante, expede a apólice, pagará em dobro o prêmio estipulado."

${ }_{335}$ Neste sentido, Vera Helena de Mello Franco (Contratos, op. cit., p. 320).

${ }^{336}$ Conforme o art. 762 do CC02 - "Nulo será o contrato para garantia de risco proveniente de ato doloso do segurado, do beneficiário, ou de representante de um ou de outro.” E também o art. 768 do CC02 - “O segurado perderá o direito à garantia se agravar intencionalmente o risco objeto do contrato."

Exceção a essa regra é a cobertura do suicídio dois anos de vigência do contrato, nos termos do art. 798 do CC02: "O beneficiário não tem direito ao capital estipulado quando o segurado se suicida nos primeiros dois anos de vigência inicial do contrato, ou da sua recondução depois de suspenso, observado o disposto no parágrafo único do artigo antecedente. Parágrafo único. Ressalvada a hipótese prevista neste artigo, é nula a cláusula contratual que exclui o pagamento do capital por suicídio do segurado." Outra exceção é o seguro de responsabilidade civil, o qual tem por objetivo indenizar um terceiro por danos causados pelo segurado. Como explica Pedro Alvim (op. cit., p. 215): “As definições que afirmaram ser o risco independente da vontade das partes não refletem mais a realidade do seguro moderno. Um de seus mais florescentes ramos, na atualidade, é o de responsabilidade civil." 
correspondente. (o que, mais uma vez, fica mais evidente no seguro de danos do que no de pessoas)

g) Ser um acontecimento futuro. Não pode depender de um acontecimento já ocorrido ou que esteja em andamento no momento da realização do contrato.

\subsubsection{Risco especulativo e risco puro}

O risco pode ter várias classificações, mas destacamos uma em especial que entendemos servir aos propósitos desta dissertação: quanto à natureza das perdas. De acordo com esse critério, o risco pode ser classificado em puro ou especulativo ${ }^{337}$.

Pode-se definir o risco especulativo como ${ }^{338}$ : "Incerteza sobre um evento em consideração que pode produzir tanto um ganho quanto uma perda, como em uma operação de negócios ou uma transação de jogo. O risco puro é geralmente assegurável, enquanto o especulativo geralmente não é”. (tradução livre)

O risco puro, por outro lado, é aquele que envolve unicamente a chance de perda. É puro no sentido de não misturar ganhos e perdas. É um risco assegurável.

Conforme a definição de Warren T. Hope ${ }^{339}$ :

Um risco puro só pode resultar em perda ou não perda, pois um risco puro não apresenta oportunidade de ganho. (...) Um risco especulativo, por outro lado, pode resultar em perda, nem perda nem ganho, ou em ganho. (...) Outra maneira de distinguir esses dois tipos de risco é dizer que riscos puros representam incertezas sobre se perdas acidentais ocorrerão. Riscos especulativos surgem de atividades exercidas intencionalmente por pessoas ou empresas porque podem resultar em ganho.

\footnotetext{
${ }^{337}$ Neste sentido também é a lição de Vera Helena de Mello Franco: O risco, segundo a autora, coberto pelo contrato de seguro, é diferente daqueles correntes no comércio ou no mercado de capitais. Lições de direito securitário. Op. cit., p. 43.

338 "Uncertainty about an event under consideration that could produce either a profit or a loss, such as a business venture or a gambling transaction. A pure risk is generally insurable, while speculative risk is usually not." Disponível em <http://www.irmi.com>, acesso em setembro/2013

${ }^{339}$ Introdução ao gerenciamento de riscos. Rio de Janeiro: FUNENSEG, 2002, p. 5.
} 
Em complementação, destacamos a lição de Luciana Staciarini Batista, Tatiana Ribeiro da Costa, Yumi Hirai e Rubens Famá ${ }^{340}$ :

O risco puro é aquele em que a perda pode ocorrer sem que haja, contudo, possibilidade de ocorrer um ganho como resultado do risco. No risco especulativo, entretanto, tem-se a possibilidade de se perder ou ganhar ao se assumir tal risco. A rigor, representa uma aposta em condições, geralmente, imprevisíveis. Este tipo de risco, embora muito incentivadas, as atividades de proteção a partir do início da década de 80, não é objeto das atividades das companhias de seguros.

Portanto, quando aludimos a risco, no contrato de seguro, estamos nos referindo ao risco puro.

Corroborando esse entendimento, Vera Helena de Mello Franco ${ }^{341}$ afirma: “o risco no contrato de seguros é o que chamamos de risco puro, que é diferente daquele especulativo, negocial ou financeiro, pois nele não há um ganho que se contrabalance com uma perda do outro lado.” (n.g.)

Há, contudo, produtos oferecidos pelo mercado segurador que só contam com o risco especulativo, e que, em nosso entendimento, não deveriam ser considerados como $\operatorname{seguros}^{342}$.

\footnotetext{
${ }^{340}$ A indústria do seguro no Brasil: uma análise comparativa das cinco maiores companhias seguradoras, Disponível em: <http://www.ead.fea.usp.br/semead/4semead/1SemeadJr/artigos/Batista_Costa_Hirai_e_Fam\%E1.pdf>. Acesso em: 14/05/13.

${ }^{341}$ Contratos. Op. cit., p. 293.

${ }^{342}$ V.g. "seguros unit linked".
} 


\section{CAPÍTULO IV - CONFRONTO DOS ELEMENTOS DO CONTRATO DE SEGURO COM OS DA PREVIDÊNCIA PRIVADA}

\subsection{Empresarialidade - entidades de previdência privada}

\subsubsection{Restrição da atividade a pessoas jurídicas}

Assim como ocorreu na história do seguro, também na previdência privada não havia, no princípio, organização jurídica estabelecida por lei, até porque, como visto, a primeira lei que regulamentou a matéria (lei 6435) só foi promulgada em 1977, de modo que as instituições existentes até então funcionaram por quase 140 anos cada qual conforme seu próprio regramento, e sem haver padrão quanto à sua forma.

Como refere Messina ${ }^{343}$ :

Antes da vigência da lei $n^{\circ} 6435 / 77$, não havia regulamentação para o setor; assim, vários tipos de entidades, em sua maioria sem adequada fiscalização pelo poder público, acabavam por exercer atividades semelhantes às previstas pela previdência social, atraindo a poupança privada, mas muitas vezes não cumprindo os compromissos assumidos, sem qualquer possibilidade de recuperação posterior por parte daqueles que nelas aportaram seus recursos.

A partir de 1977, a legislação criou as entidades de previdência privada (art. $1^{\circ}$ ), com objeto específico de "instituir planos privados de concessão de pecúlios ou de rendas, de benefícios complementares ou assemelhados aos da Previdência Social, mediante contribuição de seus participantes, dos respectivos empregadores ou de ambos". Estabeleceu forma jurídica específica ${ }^{344}$ e ainda instituiu penalidade para quem atuasse como entidade de previdência privada sem estar devidamente autorizado ${ }^{345}$.

\footnotetext{
${ }^{343}$ MESSINA, Roberto Eiras. Lei da Previdência Complementar anotada. São Paulo: Saraiva, 2011, p. 38.

${ }^{344}$ Art. $5^{\circ}$ da lei $n^{\circ}$ 6435: "As entidades de previdência privada serão organizadas como: I - sociedades anônimas, quando tiverem fins lucrativos; II - sociedades civis ou fundações, quando sem fins lucrativos."

345 Art. 80: "Qualquer pessoa que atue como entidade de previdência privada, sem estar devidamente autorizada, fica sujeita à multa, nos termos do artigo 78 desta Lei, e à pena de detenção de 1 (um) a 2 (dois) anos. Se se tratar de pessoa jurídica, seus diretores e administradores incorrerão na mesma pena."
} 
Mais tarde, a LC 109/01 confirmou, no art. $2^{\circ}$, que o regime de previdência privada somente pode ser operado por entidades de previdência complementar (fechadas ou abertas) ${ }^{346}$ :

O regime de previdência complementar é operado por entidades de previdência complementar que têm por objetivo principal instituir e executar planos de benefícios de caráter previdenciário, na forma desta Lei Complementar. (n.g.)

A restrição para o exercício da atividade justifica-se pelo relevante papel social que tem a previdência privada - tanto por ser uma extensão da previdência social, a qual é de responsabilidade do Estado ${ }^{347}$, quanto por ser um instrumento de captação de poupança popular e, como tal, não poder ficar à mercê de qualquer pessoa física ou mesmo de uma pessoa jurídica que não detenha capacitação financeira, técnica ou estrutura organizada para gerir tais recursos.

Daí se conclui que, nos termos do ordenamento jurídico pátrio, a empresarialidade é um elemento do contrato de previdência privada ${ }^{348}$.

Sobre esse tema, Messina ${ }^{349}$ sintetiza:

A previdência complementar envolve um sistema de desenvolvimento social, na medida em que pode propiciar a dignidade do ser humano, sobretudo para a etapa final de sua vida. E assenta-se em um regime de capitalização de recursos, egressos de um esforço de poupança, para utilização no futuro. Sendo da essência, pois, desse sistema, o transcurso do tempo, é natural que se imponha como elemento fundamental a relação de confiança extrema entre o participante do plano de benefícios e os respectivos gestores. Desse modo, a atuação nesse segmento não só deve ser fiscalizada como também restringida àqueles que efetivamente submetam-se às regras de sua estruturação, não o fragilizando com mentiras e atuações inconsistentes, sobretudo porque cuidam, nesse campo, desse valor absolutamente relevante, que é a confiança da população.

Na mesma linha de raciocínio é o entendimento de Balera ${ }^{350}$ :

\footnotetext{
${ }^{346}$ E também pelas seguradoras autorizadas a operar no ramo vida, conforme dispõe o parágrafo único do art. 36 da LC 109/01.

${ }^{347}$ Consoante o art. 194 da CF.

${ }^{348}$ Ainda que não seja um elemento técnico.

${ }^{349}$ Op. cit., p. 171.

${ }^{350}$ BALERA, Wagner. Sistema de seguridade social. Op. cit., p. 299.
} 
Para gerir capitais privados que, de futuro, garantirão direitos previdenciários, devem os interessados demonstrar a necessária idoneidade, capacidade de gestão e lastro estrutural suficiente. Tais atributos, submetidos ao prévio crivo da autoridade administrativa são conditio sine qua non para o exercício das funções previdenciárias complementares. (grifos do autor)

\subsubsection{Requisitos quanto à forma da entidade}

Conquanto a legislação de 1977 tenha se referido expressamente à possibilidade de as entidades abertas terem finalidade não lucrativa ${ }^{351}$, a LC 109/01 inovou ao restringir a orientação de tais entidades aos fins lucrativos, admitindo, contudo, a organização jurídica como sociedades civis $^{352}$ para as entidades abertas sem fins lucrativos já autorizadas a funcionar quando da sua publicação ${ }^{353}$.

Reza o art. 36 da LC 109/01 que as entidades abertas são constituídas unicamente sob a forma de sociedades anônimas.

Sobre tal exigência, Balera ${ }^{354}$ leciona:

As sociedades anônimas oferecem estrutura econômica com liberdade de patrimônio, além de possuírem estrutura administrativa e comercial que facilitam a operacionalidade do processo previdenciário privado e garantindo a proteção dos interesses sociais de segmentos expressivos da sociedade ativa. Também facilita a tutela da administração pública, a imposição de exigências técnico-operacionais e a respectiva fiscalização. (...) As entidades com fins lucrativos trouxeram organização, estrutura operacional e controles internos próprios nunca apresentados pelo segmento. Conseguem implementar maior produtividade, já que operam com custos reduzidos, e com rendimentos mais elevados para os participantes ativos que caucionam suas reservas técnicas, oferecendo maior rol de benefícios por custo menor.

\footnotetext{
${ }^{351}$ Conforme o art. 23 da lei no 6435.

352 As sociedades civis não foram abrigadas pelo $\mathrm{CC} 22$, que extinguiu as sociedades civis e criou as sociedades simples. Entretanto, como a LC 109/01, é anterior, essa figura aparece, ainda que na forma de um "regime de transição" que, na opinião de Marcus Orione Gonçalves Correia e José Corrêa Villela, "parece ser vir a reduzir os custos tanto de funcionamento como de adequação às novas regras para certas entidades que, na sistemática anterior, funcionavam sob a lógica da não-lucratividade.” (op. cit., p. 458)

${ }^{353}$ Nos termos do art. 77 da LC 109/01.

${ }^{354}$ BALERA, Wagner. [coord.] Op. cit., p. 227
} 
Assim sendo, as mesmas ponderações feitas com relação às sociedades anônimas (infra, item 3.8.1) no âmbito das atividades de seguros são aplicáveis às entidades abertas de previdência privada, as quais sintetizamos: (i) são mecanismos de arrecadação de poupanças e financiamento do desenvolvimento econômico e industrial; (ii) a estrutura das sociedades anônimas garante a realização dos objetivos sociais de tais entidades.

\subsubsection{Necessidade de prévia autorização da Susep}

As entidades abertas, assim como as seguradoras, dependem de prévia e expressa aprovação da Susep para seu funcionamento e comercialização de planos, conforme expressamente previsto do art. 38 da LC 109/01:

Dependerão de prévia e expressa aprovação do órgão fiscalizador: I a constituição e o funcionamento das entidades abertas, bem como as disposições de seus estatutos e as respectivas alterações; II - a comercialização dos planos de benefícios; III - os atos relativos à eleição e conseqüente posse de administradores e membros de conselhos estatutários; e IV - as operações relativas à transferência do controle acionário, fusão, cisão, incorporação ou qualquer outra forma de reorganização societária. (n.g.)

A mesma LC 109 estabeleceu no art. 67:

O exercício de atividade de previdência complementar por qualquer pessoa, física ou jurídica, sem a autorização devida do órgão competente, inclusive a comercialização de planos de benefícios, bem como a captação ou a administração de recursos de terceiros com o objetivo de, direta ou indiretamente, adquirir ou conceder benefícios previdenciários sob qualquer forma, submete o responsável à penalidade de inabilitação pelo prazo de dois a dez anos para o exercício de cargo ou função em entidade de previdência complementar, sociedades seguradoras, instituições financeiras e no serviço público, além de multa aplicável de acordo com o disposto no inciso IV do art. 65 desta Lei Complementar, bem como noticiar ao Ministério Público. (n.g.)

Complementando, a Resolução CNSP no 243/11 prescreveu penalidade para quem realizar a atividade de previdência privada sem a devida autorização, no seu art. 18: "Realizar atividade de corretagem, de auditoria ou de previdência complementar 
aberta sem a devida autorização. Sanção: multa de $\mathrm{R}$ \$ 50.000,00 (cinquenta mil) a $\mathrm{R}$ \$ 1.000.000,00 (um milhão de reais).” (n.g.)

E não é só isso. A lei no 7.492/86, que disciplina os crimes contra o sistema financeiro nacional, equiparou instituição financeira à pessoa jurídica de Direito Privado que capte recursos de terceiros, nos termos do art. $1^{\mathrm{o}}$ :

Considera-se instituição financeira, para efeito desta lei, a pessoa jurídica de direito público ou privado, que tenha como atividade principal ou acessória, cumulativamente ou não, a captação, intermediação ou aplicação de recursos financeiros de terceiros, em moeda nacional ou estrangeira, ou a custódia, emissão, distribuição, negociação, intermediação ou administração de valores mobiliários. (n.g.)

A mesma lei, no art. 16, preceituou penalidade para quem desempenhar tais operações sem a devida autorização:

Fazer operar, sem a devida autorização, ou com autorização obtida mediante declaração falsa, instituição financeira, inclusive de distribuição de valores mobiliários ou de câmbio: Pena - Reclusão, de 1 (um) a 4 (quatro) anos, e multa. Parágrafo único. Equipara-se à instituição financeira: I - a pessoa jurídica que capte ou administre seguros, câmbio, consórcio, capitalização ou qualquer tipo de poupança, ou recursos de terceiros; II - a pessoa natural que exerça quaisquer das atividades referidas neste artigo, ainda que de forma eventual.

\subsubsection{Exigências às entidades de previdência privada}

As entidades de previdência privada submetem-se à normatização, coordenação, supervisão, fiscalização e controle dos órgãos regulador e fiscalizador que, no caso das entidades abertas são, respectivamente, o CNSP e a Susep ${ }^{355}$.

Conforme o art. $6^{\circ}$ da LC 109/01, as entidades de previdência privada somente poderão instituir e operar planos de benefícios para os quais tenham autorização específica, segundo as normas aprovadas pelos órgãos competentes.

\footnotetext{
${ }^{355}$ Nos termos do art. 74 da LC 109/01.
} 
Nos termos do art. $9^{\circ}$ da mesma lei, as entidades constituirão reservas técnicas, provisões e fundos, de conformidade com os critérios e normas fixados pelo órgão regulador e fiscalizador.

Dependem ainda de prévia e expressa aprovação da Susep (art. 38 da LC 109/01):

I) a constituição e o funcionamento das entidades abertas, bem como as disposições de seus estatutos e as respectivas alterações;

II) a comercialização dos planos de benefícios;

III) os atos relativos à eleição e consequente posse de administradores e membros de conselhos estatutários; e

IV) as operações relativas à transferência do controle acionário, fusão, cisão, incorporação ou qualquer outra forma de reorganização societária.

\section{2- Mutualismo}

O mutualismo, considerado a base técnica da operação securitária, é um critério que deve ser avaliado com cautela no que toca à previdência privada.

Como já aqui salientado, o conceito de previdência privada é muito amplo. Mesmo no âmbito das entidades abertas, há diferentes tipos de produtos e duas fases bem distintas no seu ciclo de operação (acumulação e recebimento de benefícios).

Sublinhamos que a segunda fase do plano pode nem chegar a se concretizar, se o participante falecer antes da data estabelecida para a aposentadoria ou se, propositadamente, optar por não converter a renda acumulada em um benefício - seja porque optou por fazer resgates programados da sua reserva matemática, conforme sua conveniência, seja porque optou por utilizar o plano como instrumento de sucessão patrimonial, destinando-o aos seus herdeiros.

No PGBL e no VGBL, concebidos como planos de CV, a reserva matemática de um participante, durante a fase de acumulação, em nada interfere na reserva de outro participante. São "saldos de contas" individualizados, tal qual em uma poupança ou em 
outro investimento qualquer. Por essa razão, destacamos em item específico as modalidades dos planos (infra, 1.6).

Um plano de $\mathrm{CV}$, ainda que possa ter características de BD no segundo ciclo, não se apoia, durante a fase de diferimento, em cálculos atuariais. Deste modo, não se identifica o risco puro, inerente aos contratos de seguros.

$\mathrm{O}$ único risco a que os participantes de um plano $\mathrm{CV}$ ficam expostos, durante a fase de acumulação, é o financeiro ${ }^{356}$, o qual não é repartido com outros participantes, mas apenas vivenciado simultaneamente, no sentido de que se a rentabilidade de um FIE é inferior ao que se projetava, os resultados serão sentidos por todos aqueles cujos planos estavam atrelados àquele fundo.

Não há a compensação de patrimônios entre os participantes por meio da constituição de um fundo comum, ou qualquer tipo de pulverização de riscos. A reserva matemática, ainda que alocada em um mesmo FIE, é individualizada .

Se o objeto desta dissertação fosse a análise das provisões técnicas da previdência privada, por certo o mutualismo teria lugar pois, quando e se o participante opta pelo recebimento de uma renda vitalícia, por exemplo, a natureza jurídica do seu "saldo de conta" se modifica. A reserva matemática à qual até então tinha livre acesso ${ }^{357}$, é convertida na provisão técnica da entidade ou da seguradora, a qual, tal como ocorre com os seguros em geral, é um patrimônio destinado a garantir o pagamento da indenização ou capital segurado.

Embora o valor da renda pactuado com o participante guarde proporcionalidade com a reserva matemática acumulada na fase de diferimento, há mutualismo nessa segunda fase, pois a eventual sobrevivência de um participante superior à projetada será provavelmente compensada pela morte prematura de outro, no que se observa um mecanismo de pulverização de riscos, tal como ocorreria em um contrato de seguro.

\footnotetext{
356 Evidentemente, o risco atuarial acompanha o indivíduo ao longo de toda a sua vida, pois é risco relacionado com a sua existência. Contudo, do ponto de vista da entidade e do plano contratado, esse risco perde importância, pois não é um elemento a ser considerado para a estruturação do plano ou para o cálculo da responsabilidade da seguradora ou entidade de previdência.

${ }^{357}$ Observados os requisitos estabelecidos na regulamentação específica com relação aos prazos e condições para resgates e portabilidade.
} 
Esse caráter dualista dos planos em análise poderia conduzir-nos, em um primeiro momento, a uma conclusão precipitada de que o PGBL e o VGBL são produtos de natureza jurídica híbrida - como se tal situação fosse possível.

Por essa razão é que insistimos na utilização da nomenclatura "reserva matemática", para restringirmo-nos ao que denominamos "saldo de conta" que o participante detém junto à entidade durante a fase de acumulação, e não à reserva técnica, cujo "produto é o risco" 358 .

E mais do que isso: ao analisarmos um produto, é preciso levar em consideração qual a sua característica predominante. Embora tanto PGBL quanto VGBL possam ser convertidos em uma espécie de "seguro" durante a fase de recebimento de benefício, resta evidenciado, por tudo que se expôs ao longo dessa dissertação, que o principal atributo de tais produtos é o caráter de investimento. Tanto é que, conforme demonstrado, parte significativa dos participantes sequer chega a cogitar da contratação de uma renda. $\mathrm{O}$ apelo de tais produtos, considerando o bancassurance que marca nossa época, é puramente de investimento, sendo os PGBLs e os VGBLs comercializados no mesmo "balcão" de outros produtos financeiros.

Ainda que a previdência privada tenha surgido com outros propósitos, notadamente de complementar a previdência social ou de garantir um valor em caso de sobrevivência do participante a determinado período, seu atual estágio evolutivo é esse: é estruturada, comercializada e compreendida como um produto de investimento, com toda a flexibilidade que os investimentos detêm.

Por essa razão, optamos por destacar nesse trabalho também a existência dos FAPIs, ainda que produtos de pequena expressividade no Brasil, mas por refletirem exatamente essa ideia: se os planos de seguro devem operados por seguradoras, que detém estrutura técnica, profissional e operacional para oferecê-los, o mesmo não se pode dizer dos FAPIs, que são comercializados também por instituições financeiras. Só quando o plano apresenta um componente atuarial é que emerge a necessidade de ser operado por

\footnotetext{
${ }^{358}$ Cantanhede e Ferreira, op. cit. p. 1.
} 
seguradora. No FAPI, não havendo tal componente e, portanto, não se fazendo presente o mutualismo, dispensa-se a figura da seguradora.

\section{3- Garantia}

Retomando a ideia de Comparato (infra, item 3.8.3) de que haveria um terceiro tipo obrigacional ${ }^{359}$, e que o "conteúdo das obrigações de garantia é a eliminação de um risco que pesa sobre o credor" ${ }^{, 360}$, observa-se claramente a diferença entre a prestação no contrato de seguro e no de previdência privada.

A obrigação da entidade de previdência privada, nos planos de CV, durante a fase de acumulação, é de geri-los e acompanhar os investimentos dos recursos pelas instituições financeiras designadas.

Aqui, diferentemente do que ocorre no seguro, não existe a prestação de uma garantia com relação a um evento futuro e incerto, ou a eliminação de um risco sobre o participante, mas sim uma obrigação certa, de que a entidade deverá restituir ao participante a reserva matemática por ele acumulada.

Se, eventualmente, o participante optar pela contratação de uma renda, a prestação da entidade ou da seguradora automaticamente transmuda-se, pois, aí sim, haverá uma prestação de garantia de pagamento de indenização, de natureza securitária.

Entretanto, o objeto desta dissertação é a análise da reserva matemática dos planos e, com relação a essa reserva, não cabe falar em garantia, mas sim na devolução dos recursos aportados.

Por essa razão, dada a diferença de natureza da prestação da seguradora com relação aos seguros, e da entidade de previdência a respeito dos planos, conclui-se que a garantia não é um elemento dos contratos previdenciários privados.

\footnotetext{
${ }^{359}$ Obrigação de garantia.

${ }^{360}$ COMPARATO, Fabio Konder. Obrigações. Op. cit. p.537.
} 


\section{4- Interesse}

O interesse também tem caráter diferente nos planos de $\mathrm{CV}$, quando comparados aos seguros.

Primeiramente, porque os planos de previdência privada, na maioria das vezes ${ }^{361}$, são contratados pelos próprios participantes que, por óbvio, têm interesse na sua própria vida e, em regra geral, na sua longevidade.

Uma terceira pessoa, estranha ou que não tivesse interesse na vida do participante, dificilmente teria motivos para constituir em seu favor uma reserva financeira a ser utilizada por ele próprio (como em um plano de CV) - a não ser que tal pessoa pretendesse, por exemplo, figurar como beneficiária de uma cobertura de risco associada a este plano. Neste caso, aplicar-se-iam as regras referentes ao seguro de pessoas e, caso não estivesse comprovado o interesse na vida do participante, tal situação seria tratada nos termos do art. 790 do $\mathrm{CC} / 02^{362}$. Isso porque, nessa hipótese, esse beneficiário poderia se tornar um desejador ou provocador do sinistro, pois a ele poderia interessaria mais o recebimento da indenização do que a vida do participante.

Contudo, como o objeto deste trabalho é analisar a reserva matemática, a hipótese acima não merece considerada.

Por terem os planos de previdência privada alguma similitude com os objetivos dos seguros com cobertura por sobrevivência, transcrevemos a seguir a lição de Ascarelli $^{363}$ :

É óbvio, todavia, o motivo pelo qual o interesse não é concretamente disciplinado, de vez que de um lado seria obviamente ilícito qualquer obstáculo aos esforços do segurado para alcançar vida mais longa e, de outro lado, não foi descoberto o elixir da longa vida que permitiria, em

\footnotetext{
${ }^{361}$ Exceção, por exemplo, aos planos constituídos pelos pais em nome dos filhos menores de idade.

362 Art. 790: "No seguro sobre a vida de outros, o proponente é obrigado a declarar, sob pena de falsidade, o seu interesse pela preservação da vida do segurado. Parágrafo único. Até prova em contrário, presume-se o interesse, quando o segurado é cônjuge, ascendente ou descendente do proponente."

363 Op. cit., pp. 350-351.
} 
tais hipóteses, tornar voluntariamente por demais gravosa a prestação do segurador. (n.g.)

E continua o doutrinador ${ }^{364}$ :

Com efeito, a norma que impusesse dever, o estipulante, ter interesse na sobrevivência do segurado não alcançaria a disciplina do interesse segurável, nos seguros para o caso de vida, porque nestes (ao contrário do que acontece no seguros para o caso de morte) o lucro é tanto maior quanto mais longa a vida do segurado!

Ou seja, em um seguro por morte, por exemplo, o interesse consiste no fato de o segurado não desejar o risco; de outra ponta, no seguro por sobrevivência, o interesse significa o segurado não desejar a sua morte, o que é natural, não sendo nem razoável nem adequado à ordem pública e aos bons costumes punir o participante que, de alguma forma, conseguisse ampliar sua longevidade, caso isso fosse possível.

Contudo, a ponderação acima também não se aplica à reserva matemática, uma vez que nos planos de CV a obrigação final da entidade é de restituir o saldo de conta ao participante ou, em caso de sua morte, ao beneficiário. Não importa, para essa finalidade, qual o valor desse saldo, nem o tempo de duração da relação que foi estabelecida, tampouco a quem o valor será pago.

Logo, o interesse também não é um elemento do plano previdenciário privado de CV na fase de diferimento, não interferindo no destino da reserva matemática acumulada.

\section{5- Prêmio e contribuição}

Como destacamos (infra, item 1.5.5), um dos princípios comuns à previdência social e previdência privada é o da contributividade.

Portanto, é da essência da previdência privada o pagamento da contribuição, constituindo a prestação a cargo do participante elemento fundamental do contrato.

${ }^{364}$ Op. cit., p 351. 
Em um plano de CV, como é o caso do PGBL e do VGBL, quanto mais recursos forem aportados na fase de acumulação, maior será a reserva matemática, sendo o inverso também verdadeiro. Se um participante efetuar contribuições de valores módicos, a consequência direta será um valor de benefício singelo, uma vez que a medida da obrigação da entidade, em tais planos, corresponde ao "saldo de conta" constituído.

Entretanto, cabe-nos destacar uma diferença com relação aos seguros: ao passo que no contrato de seguro o prêmio não é revertido diretamente para o segurado, pois irá integrar um fundo mutualista, podendo ou não ser direcionado para si (conforme a materialização ou não um sinistro que dê origem ao pagamento de indenização), em um plano CV a contribuição é automaticamente direcionada ao participante.

Nos contratos sinalagmáticos, a inadimplência de uma parte compromete a obrigação que se espera da outra. No contrato de seguro, a falta do pagamento do prêmio rompe com o mutualismo, ameaçando o equilíbrio da operação. Já no contrato de previdência privada, em um plano $\mathrm{CV}$, a falta de pagamento das contribuições afeta unicamente o saldo da reserva matemática; a entidade ou seguradora, nesses casos, não deixa de prestar algum tipo de garantia, com ocorre no seguro, já que sua obrigação restringe-se à devolução dos recursos que lhe foram confiados. Quanto menor for a reserva matemática acumulada, menores serão os valores a serem restituídos pela entidade ou seguradora ao participante, mas este não perde o direito ao seu saldo por ter interrompido o pagamento das contribuições - diferentemente do que ocorre em um contrato de seguro ${ }^{365}$.

Assim, dada a diferença significativa de natureza entre o prêmio e a contribuição, não se pode afirmar que o prêmio seja um elemento do contrato de previdência privada em análise, dado que o prêmio relaciona-se diretamente com o mutualismo, o qual não existe na fase de acumulação dos planos de CV.

\section{6- Risco - risco puro e risco especulativo}

\footnotetext{
${ }^{365}$ Conforme o art. 763 do Código Civil: "Não terá direito a indenização o segurado que estiver em mora no pagamento do prêmio, se ocorrer o sinistro antes de sua purgação."
} 
Por todo o exposto, observa-se que os planos de CV apresentam unicamente o risco especulativo e não o risco puro.

Fabiana Lopes da Silva ${ }^{366}$ ensina que o risco especulativo de uma entidade de previdência privada pode ser de vários tipos:

(iii) risco de crédito, que pode ser interno (o participante ou o instituidor de um plano coletivo de entidade aberta de previdência privada não honrar com as contribuições a que se comprometeu) ou externo (possibilidade de os devedores, tais como o emissor de um instrumento financeiro, não honrarem os pagamentos assumidos);

(iv) risco operacional, entendido como o risco de perdas diretas ou indiretas, como resultado de inadequações ou falhas de processos internos, de pessoas e sistemas, ou de eventos externos (conforme a Resolução BACEN no 3380 , art. $2^{\circ}$ ), podendo incluir fraudes internas ou externas, práticas inadequadas relativas a clientes, produtos e serviços, falhas em sistemas de tecnologia de informação, dentre outros; (v) risco legal, que consiste na adoção de práticas inadequadas pelas entidades, que possam violar regulamentações governamentais ou ainda mudanças regulatórias ou de legislação que possam impactar nos direitos dos participantes; e

(v) risco institucional, que se relaciona com ações tomadas pela entidade ou gestor de recursos que possam contribuir para o aumento da volatilidade dos ativos e passivos, ou com a má administração dos ativos garantidores.

${ }^{366}$ Op. cit, pp. $44-46$. 
Só há o risco puro, típico dos contratos de seguro, nos planos que preveem coberturas de risco como, por exemplo, quando há a contratação de uma renda vitalícia. Contudo, na fase de acumulação dos planos de CV, objeto deste estudo, este risco não existe.

Tzirulnik, Cavalcanti e Pimentel ${ }^{367}$ explicam que:

O risco é o elemento sine qua non para a formação da taxa a ser aplicada para o cálculo do prêmio. Essa taxa resulta das contas atuariais que, como afirmamos, permitem compreender economicamente as incertezas individuais, convolando-as em risco no contexto coletivo e nele dissolvendo-as.

E os mesmos autores ${ }^{368}$ evidenciam essa ausência de risco nos planos de previdência privada:

Nesses planos [PGBL e VGBL], o valor da prestação da seguradora não é definido no ato da contratação, sendo uma mera meta a ser atingida. $\mathrm{O}$ prazo contratado é mera referência, sendo que os aportes financeiros realizados podem ser feitos no valor que o titular do plano desejar e quando desejar. O benefício ao final do prazo será estabelecido em razão do valor poupado. Tais planos não são, a rigor, seguros, pois, no prazo de diferimento [reserva matemática], não há nenhum elemento de risco. É mera acumulação financeira. (n.g.)

Com o valor acumulado, poderá o titular, caso assim o deseje, contratar o benefício de renda, caracterizando, a partir desse momento, um verdadeiro seguro com a introdução do elemento de risco, qual seja, o tempo de recebimento da renda em relação ao montante da reserva constituída. A morte logo após o início do recebimento do benefício é o risco do segurado e sua sobrevivência além do previsto é o da seguradora e, também, nessa hipótese, a reserva de um subsidiará o benefício de outro.

O doutrinador espanhol Tapia Hermida ${ }^{369}$ reconhece essa mesma situação no Direito espanhol: conclui que, para qualificar um contrato como de seguro, por meio de

\footnotetext{
${ }^{367}$ Op. cit., p. 38.
}

${ }^{368}$ Op. cit., p. 156. 
uma interpretação sistemática da legislação (em especial dos artigos 1 e 3 da lei espanhola do contrato de seguros), é necessário verificar se houve o deslocamento do risco sobre a vida para o patrimônio da seguradora, por meio do pagamento de um prêmio. Como afirma Tapia Hermida ${ }^{370}$ : “se não há o deslocamento [do risco sobre a vida para o patrimônio da seguradora], falta uma verdadeira existência de cobertura pela seguradora e de aleatoriedade no contrato e, portanto, não se pode qualificar o mesmo como seguro de vida por falta de causa.” (Tradução livre)

Conforme Tapia Hermida ${ }^{371}$, o fato de nos "seguros com acumulação e investimentos" o risco do investimento ser suportado pelo próprio tomador do seguro, e não pela seguradora, contraria a ideia de que tais produtos são seguros, aproximando-os do resto dos produtos financeiros e de investimento. Para determinar se houve o deslocamento do risco para a seguradora, nas palavras do autor ${ }^{372}$ :

É fundamental a aplicação de técnicas atuariais, no sentido de combinar os elementos biométricos (tábuas de mortalidade) e financeiros (taxas de juros), de modo que, se o contrato examinado só levar em conta a aplicação de critérios financeiros, não estaremos diante de um seguro de vida, mas sim de uma operação financeira ou de poupança. (Tradução livre)

Tapia Hermida finaliza ${ }^{373}$, referindo-se aos seguros a prêmio único:

$\mathrm{Na}$ prática, uma operação financeira consistente no pagamento, pelo contratante, de um único pagamento em troca do compromisso da seguradora de lhe pagar uma prestação determinada quanto à sua duração e valor, é classificada como um contrato de capitalização, cuja causa não

369 Aspectos polémicos y novedosos del Seguro de Vida, in Documentos de Trabajo del Departamento de Derecho Mercantil, Universidad Complutense, março de 2006. Disponível em: 〈http://www.ucm.es/eprints〉. Acesso em: 01/07/ 12, p. 17.

370 "Si no se produce tal desplazamiento, falta una verdadera existencia de cobertura por la entidad aseguradora y de aleatoriedad en el contrato y, por lo tanto, no puede calificarse el mismo como seguro de vida por falta de causa". Aspectos polémicos y novedosos. Op. cit., p. 17.

${ }^{371}$ Idem, p. 12.

372 "Se añade que, para determinar en cada caso si se ha producido tal desplazamiento de riesgo, es de importancia decisiva la aplicación de la técnica actuarial, en el sentido de combinar los elementos biométricos (tablas de mortalidad) y financieros (tipos de interés técnico); de modo tal que si en el contrato examinado, solo se tiene en cuenta la aplicación de criterios financieros, no nos encontraremos ante un seguro de vida sino ante una operación de ahorro.” Idem, p. 18.

373 "En concreto, una operación financiera consistente en el pago por el contratante de un desembolso único a cambio del compromiso de la aseguradora de pago de una prestación determinada en cuanto a su duración e importe, se ha calificado como un contrato de capitalización cuya causa no es la cobertura de un riesgo, sino la formación de un capital en el que, aun cuando se utiliza la técnica actuarial, tiene escasa trascendencia económica que el asegurado sobreviva o fallezca, ya que lo único que varía es la persona a la que habrá que restituir la suma asegurada." Idem, pp. 15-16. 
é a cobertura de um risco, mas sim a formação de um capital em que, ainda que se utilize a técnica atuarial, tem escassa transcendência econômica o fato de o segurado sobreviver ou falecer, já que o único elemento que varia é a pessoa a quem se terá de restituir o capital segurado. (n.g.) (Tradução livre)

Ou seja, o autor afirma que uma operação financeira constituída basicamente pela entrega de uma quantidade de recursos à seguradora por meio de um desembolso único tendo como contraprestação o pagamento de uma prestação determinada qualifica-se como um contrato de capitalização, cuja causa não é a cobertura de um risco, mas a formação de um capital. Ainda quando se utiliza uma técnica atuarial, tem escassa transcendência econômica o fato de o segurado sobreviver ou falecer, já que a única diferença seria a pessoa a quem se teria de restituir o capital segurado ou a reserva matemática.

Poderíamos adotar o mesmo raciocínio para os produtos em análise neste trabalho. Se estivermos diante de um plano de CV, pelo fato de não haver aplicação de critérios atuariais e a obrigação da entidade ou seguradora consistir na devolução de um capital aportado, não se está diante de um seguro, mas, sim, de um contrato de "capitalização",374 ou investimento.

A doutrina italiana corrobora esse entendimento. Donati e Putzolu ${ }^{375}$, referindo-se a esse contrato de capitalização (que na Itália funciona como uma operação "securitária" e caracteriza-se pela assunção da seguradora de pagar, ao término de um prazo predeterminado, que não poderá ser inferior a cinco anos, o valor acumulado pelo segurado), explicam:

A capitalização é, portanto, uma operação puramente financeira. A prestação da seguradora não está relacionada com eventos relativos à vida humana; a seguradora não assume, em outras palavras, um risco demográfico, mas apenas um risco de investimento dos montantes pagos a título de prêmio. Mais precisamente, a seguradora compromete-se a

\footnotetext{
${ }^{374}$ Nomenclatura adotada na Europa Ocidental.

375 "La capitalizzazione è quindi una operazione meramente finanziaria. La prestazione dell'assicuratore non è collegata al verificarsi di eventi attinenti allá vita umana; l'assicuratore non assume, in altre parole, un rischio demográfico, ma soltanto un rischio di investimento delle somme pagate a titolo di premio. Più precisamente l'assicuratore si impegna a versare allá scadenza un capitale costituito dalle somme versate dal contraente aumentate degli interessi al tasso garantito (c.d. tasso tecnico) o dei rendimenti di una gestione separata di strumenti finanziari, a loro volta reinvestiti (capitalizzati) e quindi produtivi di altri interessi o rendimenti. La capitalizzazione, pertanto, si differenzia nettamente dall'assicurazione sulla vita, perchè manca Il rischio demografico.” (n.g.) Op. cit., pp. 197-198.
} 
pagar, na velhice, um capital constituído pela soma das quantias pagas pelo contratante, acrescida de juros a taxa garantida (juros técnicos) ou do rendimento de uma gestão separada de instrumentos financeiros, por sua vez reinvestidos (capitalizados) e, em seguida, produção de outros juros ou rendimentos. A capitalização, portanto, diferencia-se marcadamente do seguro de vida, porque lhe falta 0 risco demográfico. (n.g.) (Tradução livre)

Citamos, por fim, o precedente jurisprudencial inglês "Fuji Finance Inc X Aetna Life Insurance"376, em que se decidiu que em um "unit linked bond ${ }^{377, ", ~ n o ~ q u a l ~ o ~ v a l o r ~ a ~}$ receber em caso de morte era o mesmo que foi acumulado, não era, portanto, um seguro. John Lowry, Philip Rawlings e Robert Merkins ${ }^{378}$, sobre este assunto, explicam:

Se não houver tentativa para vincular o montante do prêmio ao risco, isso pode indicar que o contrato não é de seguro. Isso poderia excluir as ofertas de "seguro livre", uma vez que mesmo que seja possível encontrar considerações, ele não é baseado em cálculos atuariais.

No mesmo sentido é o entendimento de Tony Wickenden ${ }^{379}$ : “Um contrato será um seguro de vida se o pagamento do capital segurado, independentemente de qualquer direito de arrependimento, depende da vida humana." (tradução livre) Para o autor, no produto em análise [unit linked] o valor da indenização por morte ou sobrevivência depende somente do desempenho dos investimentos e não se relaciona com o risco de mortalidade, pois o valor a ser recebido é o saldo da reserva matemática.

Portanto, observa-se com fartos exemplos doutrinários que o risco puro é um elemento essencial para a caracterização de um produto como securitário, e que quando o plano não é estruturado tendo por base elementos atuariais e o valor a ser pago pela seguradora ou entidade de previdência privada depende tão somente do desempenho dos investimentos, não estamos diante de um seguro, mas sim de um produto financeiro.

\footnotetext{
${ }^{376}$ Fuji Finance contratou um "single premium bond" sobre a vida de Gary Tait, um dos principais executives da Fuji. Pagaram um prêmio de US\$ 50 mil (cinquenta mil dólares). Este valor seria revertido à Fuji em caso de morte de Gary. A apólice previa que a seguradora investisse os recursos e que a Fuji resgatasse-os a qualquer tempo. Observou-se, assim, que a morte do Sr. Tait não afetava o valor a ser recebido.

377 Produto financeiro estruturado como "seguro".

378 "If there were no attempts to link the amount of the premium to the risk, this might indicate that the agreement was not an insurance contract. This might exclude "free insurance' offers since even if it is possible to find consideration it will not be based on an actuarial calculation." Insurance Law - Doctrine and Principles. $3^{\mathrm{a}}$ ed. Oxford: Hart Publishing, 2011. Pp. 156-157.

379 "A contract will be one of life insurance if payment of the sum assured, regardless of any surrender rights, is dependent on human life." The meaning of life insurance, Disponível em: <http://www.moneymarketing.co.uk/the-meaning-of-life-insurance/120077.article>. Acesso em: 04/10/2013.
} 


\section{CAPÍTULO V - CONSIDERAÇÕES FINAIS}

Este trabalho teve por objetivo perseguir a natureza jurídica do "saldo de conta" de que o participante de um plano de Contribuição Variável de entidade aberta de previdência privada é titular, o qual intitulamos "reserva matemática", com o intuito de analisar se esse saldo tem os atributos de um contrato de seguro. Dessa investigação, resultaram as principais conclusões sintetizadas a seguir:

1. A atitude de se precaver para o futuro acompanha o homem há dezenas de milhares de anos, embora tenha sido no último século que sua preocupação ficou maior, por ter conquistado uma longevidade jamais experimentada.

2. Se, por um lado, viver mais representa superação de obstáculos, por outro significa um novo desafio: acumular recursos para garantir a subsistência na velhice.

3. Embora a previdência social seja um sistema orientado para proteger a população contra os riscos que afetam o trabalhador com relação à sua renda, nos últimos anos o Estado limitou sua participação e ampliou o espaço para atuação de particulares, inclusive para entidades de previdência privada.

4. A previdência privada é um instituto que caminha para dois séculos de existência no Brasil, mas sua regulamentação é relativamente recente, e seu desenvolvimento efetivo somente ocorreu após a implantação do Plano Real.

5. O regime previdenciário privado, com relação ao regime social, é complementar e autônomo, diferenciando-se ainda por ser facultativo e baseado na constituição de reservas, no que se evidencia o seu caráter contributivo.

6. As entidades de previdência privada e seguradoras devem constituir provisões técnicas para suportar os riscos a que se propõem a assumir, com base em metodologias de pulverização de riscos. 
7. As provisões técnicas não se confundem com as reservas matemáticas, que são "saldos de conta" constituídos pelos aportes feitos em nome dos participantes, passíveis de resgate e que não integram o mutualismo.

8. Os planos previdenciários privados podem ser estruturados como $\mathrm{BD}, \mathrm{CD}$ e $\mathrm{CV}$, sendo que os protagonistas do mercado de previdência privada aberta brasileiro (PGBL e VGBL) são constituídos como CV.

9. Nos planos de CV, durante a fase de acumulação, não há mutualismo, pois os aportes integram contas individualizadas em nome de cada participante. Não há aplicação de fatores atuariais e a obrigação da entidade ou seguradora restringe-se à devolução dos valores que lhes foram confiados.

10. Atualmente, por conta do fenômeno do bancassurance, há certa dificuldade em delimitar os produtos financeiros, seguros e planos previdenciários, pois as alianças comerciais estratégicas seladas entre instituições financeiras, fundos de investimento e seguradoras propiciaram a criação de certos produtos de natureza suis generis, os quais, embora denominados "seguros", têm verdadeira natureza de investimentos.

11. Os seguros sociais não se confundem com os seguros privados, tanto pela forma de filiação quanto pelos aspectos relacionados ao financiamento, à instrumentalização da relação, os tipos de riscos cobertos, a aplicação do princípio de solidariedade que rege os primeiros e o mutualismo que predomina nos segundos, e pelos próprios responsáveis pela administração de cada tipo.

12. Embora a previdência privada seja complementar à previdência social, ela não é considerada um seguro social, apresentando mais pontos em comum, pela sua estrutura, com os seguros privados.

13. Os seguros de pessoas com cobertura por sobrevivência têm finalidade semelhante à dos planos previdenciários privados, por serem ambos produtos orientados a prover recursos ao participante que sobreviver a determinado período. 
14. Os seguros caracterizam-se pela existência de elementos jurídicos e técnicos. Os elementos jurídicos, conforme o Código Civil brasileiro, são: empresarialidade, garantia, interesse, prêmio e risco. Sublinhou-se, ainda, neste trabalho, um elemento técnico - o mutualismo, por se ter entendido ser decorrente da empresarialidade e a base da operação securitária.

15. Do confronto dos elementos do contrato de seguro com os dos planos de previdência privada de $\mathrm{CV}$, constatou-se alguma convergência com relação à empresarialidade, porque em ambos faz-se necessária, nos termos do ordenamento jurídico brasileiro, a existência de uma organização empresarial para o desenvolvimento das atividades inerentes.

16. Contudo, nos contratos de seguros a empresarialidade é uma estrutura que, dentre outros fatores, vincula-se ao mutualismo, o qual não existe nos planos de CV, já que a reserva matemática dos participantes é individualizada, não integrando qualquer estrutura de pulverização de riscos.

17. A prestação das entidades de previdência privada tem natureza diferente da garantia prestada pelas seguradoras, à medida que o pagamento da indenização obrigação secundária em um contrato de seguro - pode nem chegar a se concretizar, se o sinistro não for materializado. De outro lado, o pagamento do benefício ou a devolução do saldo da reserva matemática do plano previdenciário privado é certo, ainda que não se possa precisar o momento exato em que será feito, nem a quem será realizado - se ao participante ou se a um beneficiário, em caso de sua morte.

18. O interesse também não integra o contrato de previdência privada de $\mathrm{CV}$, pois nesta operação a obrigação da seguradora restringe-se à devolução dos valores que a ela foram confiados, não importando se o participante abreviou sua vida, ou se sua longevidade é superior à projetada, pois os recursos a serem restituídos serão sempre aqueles aportados na reserva matemática.

19. O prêmio do seguro tem natureza diversa das contribuições previdenciárias, pois é destinado à composição da reserva técnica da seguradora, ou seja, ao fundo 
mutualista designado ao pagamento das indenizações referentes aos sinistros ocorridos com outros segurados que também contribuíram para esse fundo. As contribuições dos planos de CV destinam-se à reserva matemática, individualizada, que é o "saldo de conta" a que o participante tem direito em caso de resgate, portabilidade ou contratação de uma renda.

20. Por fim, o risco que existe nos planos de previdência privada de $\mathrm{CV}$, e que se relaciona com os valores aportados na reserva matemática é apenas o risco financeiro (típico das operações financeiras) e não o risco puro ou atuarial, próprio dos contratos de seguros.

Assim, por não haver equiparação, a não ser pelo fator empresarialidade, entre os elementos dos contratos de seguros e os contratos de previdência privada estruturados como $\mathrm{CV}$, não se pode afirmar que a reserva matemática em tais planos tenha natureza securitária.

Porque os planos previdenciários privados, os seguros e os produtos financeiros passaram por um processo de convergência ao longo dos últimos anos, com o bancassurance, pode-se concluir que os planos que dominam o mercado brasileiro de previdência privada aberta atual são verdadeiros instrumentos financeiros. A reserva matemática desses produtos, por conseguinte, não se confunde com a provisão técnica dos seguros, não se justificando que a ela se apliquem os princípios e normas que regem a operação securitária. 


\section{REFERÊNCIAS}

ABREU, Marcelo de Paiva; FERNANDES, Felipe Tâmega. The insurance industry in Brazil: a long-term view. Working Paper 10-109, Harvard Business School, 2010. Disponível em <http://www.hbs.edu/faculty/Publication\%20Files/10-109.pdf>, acesso em 21/12/13.

AFONSO, Luís Eduardo. Previdência social e fundos de pensão. Rio de Janeiro: FUNENSEG, 1996.

ALBERTI, Verena (coord.). Entre a solidariedade e o risco: história do seguro privado no Brasil. 2a Ed. Rio de Janeiro: 2001.

ALCOVA, Camila. Com juros baixos, renda vitalícia é o grande desafio para a previdência privada. Disponível em $<$ http://www.revistacobertura.com.br/lermais_materias.php?cd_materias=89192>. Acesso em: 06/09/13.

ALMEIDA, J. C. Moitinho de. O contrato de seguro no direito comparado. Lisboa: Livraria da Costa, 1971.

ALMIRO, Affonso. Teoria do Direito Previdenciário brasileiro e bibliografia previdenciária brasileira. Rio de Janeiro: IBDP, 1984.

ALPA, Guido (coord.) Giurisprudenza sistematica di diritto civile e commerciale. Torino: UTET giuridica, 2006.

ALVIM, Pedro. O contrato de seguro. $3^{\text {a }}$ ed. Rio de Janeiro: Forense, 2001.

AMARAL, Hudson Fernandes et al . Fundos de pensão como formadores de poupança interna: uma alternativa para o financiamento da atividade econômica. Rev. adm. contemp., Curitiba, v. $8, \mathrm{n}^{\mathrm{o}} 2$, jun/2004. Disponível em: 
<http://www.scielo.br/scielo.php?script=sci_arttext\&pid=S1415-

65552004000200008\&lng=pt\&nrm=iso>. Acesso em: 07/09/2013.

AMARAL FILHO, Léo do. Previdência Privada Aberta. São Paulo: Quartier Latin, 2005.

ARNOTT, Richard; STIGLITZ, Joseph. Moral Hazard and Nonmarket Institutions: Dysfunctional Crowding Out of Peer Monitoring? American Economic Association, disponível em <http://www.jstor.org/stable/2006794.> . Acesso em 22/08/13.

ASCARELLI, Tullio. Problemas das sociedades anônimas e direito comparado. Campinas: Bookseller, 1999.

AZEVEDO, Luiz Augusto Roux. A comutatividade do contrato de seguro. Dissertação de Mestrado em Direito Comercial). Faculdade de Direito da Universidade de São Paulo, São Paulo, 2010. Disponível em: <http://www.teses.usp.br/teses/disponiveis/2/2132/tde25082011-134415/pt-br.php>. Acesso em: 09/07/2013.

BAENA, Pedro Jesús Baena. El derecho de rescate de la provisión matemática des seguro de vida. Valencia: Tirant le Blanch, 2008.

BALERA, Wagner [coord.]. Comentários à lei de previdência privada. São Paulo: Quartier Latin, 2005.

) [coord.] Curso de Direito Previdenciário. Homenagem a Moacyr Velloso Cardoso de Oliveira, $5^{\text {a }}$ ed. São Paulo: LTr, 2002.

(__ Sistema de seguridade social. $4^{\text {a }}$ ed. São Paulo: LTr, 2006.

BATISTA, Luciana Staciarini; COSTA, Tatiana Ribeiro da; HIRAI, Yumi; Famá, Rubens. A indústria do seguro no Brasil: uma análise comparativa das cinco maiores companhias seguradoras, Disponível em: <http://www.ead.fea.usp.br/semead/4semead/1SemeadJr/artigos/Batista_Costa_Hirai_e_Fa m\%E1.pdf>. Acesso em: 14/05/13. 
BAYÃO, Enéas Virgílio Saldanha. Responsabilidade civil, administrativa e criminal dos dirigentes de EFPC in Gestão de Fundos de Pensão: Aspectos Jurídicos. Wagner de Góes (coord.). São Paulo: Associação Brasileira das Entidades Fechadas de Previdência Complementar - ABRAPP, 2006.

BECHARA, Ricardo. Contrato de seguro. aleatório ou comutativo? Disponível em < www.oabsp.org.br/comissoes2010/direito-securitario/artigos/.../download>, acesso em 07/08/13.

BECK, Ulrick. Sociedade de risco - rumo a uma outra modernidade. São Paulo, Editora $34,2010$.

BELTRÃO, Kaizô Iwakami; PINHEIRO, Sonoe Sugahara. Estimativas de mortalidade para a população coberta pelos seguros privados. Texto para discussão $\mathrm{n}^{\circ} 868$. Rio de Janeiro, 2002. Disponível em: <http://www.ipea.gov.br>. Acesso em 12/10/13.

BEVILAQUA, Clóvis. Código Civil dos Estados Unidos do Brasil. v. 5. Rio de Janeiro: Rio, 1952.

CANUTO, Alessandra Mihailidou; FERNANDES, Maria Fernanda Otero. O crescimento da previdência privada aberta face à crise da previdência social. Disponível em: <http://www.mackenzie.br/fileadmin/Graduacao/CCSA/Publicacoes/Jovens_Pesquisadores /02/2_2_09.pdf>. Acesso em: 10/07/13.

CASTEllanO Gaetano. I Prodotti Finanziari Bancari ed Assicurativi in Quaderni di Giurisprudenza Commerciale. Milão: Giuffré, 2008.

CAVICCHINI, Alexis. A história dos seguros no Brasil: 1808, 2008. Rio de Janeiro, Cop. Editora, 2008.

CITIBANK. Planos PGBL/VGBL. Disponível em <https://www.citibank.com.br/investimentos/previdencia/planos_pgbl_vgbl.html>, acesso em $01 / 11 / 13$. 
CLARKE, Malcolm. Policies and perspectives of insurance Law in the twenty-first century. New York: Oxford University, 2005.

COMPARATO, Fábio Konder. Substitutivo ao capítulo referente ao contrato de seguro no anteprojeto do Código Civil in Revista de Direito Mercantil, Industrial, Econômico Financeiro. Ano XI (Nova Série), nº 5. São Paulo: Revista dos Tribunais, 1972.

CORDEIRO, António Menezes. Direito dos Seguros. Coimbra: Almedina, 2013.

CORREIA, Marcus Orione Gonçalves; CORREIA, Érica Paula Barcha. Curso de Direito da Seguridade Social. São Paulo: Saraiva, 2008.

CORREIA, Marcus Orione Gonçalves (coord.); VILLELA, José Corrêa (org.). Previdência Privada. Doutrina e Comentários à Lei Complementar no 109/01. São Paulo: LTr, 2004.

COSTA, Eliane Romeiro. Previdência Complementar na Seguridade Social - o risco velhice e a idade para a aposentadoria. São Paulo: LTr, 2003.

COSTI Renzo. I prodotti finanziari, bancari ed assicurativi in I prodotti finanziari, bancari ed assicurativi . CASTELLANO, Gaetano (coord). Milão: Giuffré, 2008.

DEL FIORI, Alexandre. Dicionário de seguros. São Paulo: Manuais Técnicos de Seguros, 1996.

DAMODARAN, Aswath. Gestão estratégica do risco. Porto Alegre: Bookman, 2003.

DIONYSIO, Renata Barbosa; MEIRELLES, Fatima Ventura Pereira. Conservação de alimentos. Disponível em <http://web.ccead.pucrio.br/condigital/mvsl/Sala\%20de\%20Leitura/conteudos/SL_conservacao_de_alimentos.pd $\mathrm{f}>$, acesso em 02/01/14.

DONATI, Antigono; PUTZOLU, Giovanna Volpe. 10a ed. Manuale di Diritto Delle Assicurazioni. Milão: Giuffrè, 2012. 
DONATIVI, Vincenzo. La distribuzione bancaria di prodotti assucurativi, in Banche ed Assicurazioni fra cooperazione e concorrenza. Milão: Giuffrè, 1997.

DUTRA Bruno, Aumento na expectativa de vida do brasileiro preocupa Previdência. Disponível em: <http://economia.ig.com.br/financas/aposentadoria/2013-08-05/aumentona-expectativa-de-vida-do-brasileiro-preocupa-previdencia.html>. Acesso em: 02/09/13.

FACAL, Carlos José María El seguro de vida en la Argentina, Buenos Aires: Lexis Nexis, 2007.

FENAPREVI. Dados Estatísticos do Segmento de Pessoas. Disponível em <http://www.cnseg.org.br/fenaprevi/estatisticas/estatisticas.html>. Acesso em 02/09/13.

FLANDRIN, Jean-Louis; MONTANARI, Massimo. História da Alimentação - Os Tempos Modernos. São Paulo: Estação Liberdade, 1998.

FONTES, Rosa; ARBEX, Marcelo A.; SILVA JR, Geraldo E. Estabilização econômica no Brasil: reflexões sobre o Plano Real in Estabilização e crescimento: desafios do Plano Real. Disponível em http://revistas.fee.tche.br/index.php/indicadores/article/viewFile/1570/1938>. Acesso em $12 / 01 / 12$

FRANCO, Vera Helena de Mello. Contratos no direito privado. $3^{\mathrm{a}}$ ed. São Paulo: Revista dos Tribunais, 2012.

(_ Lições de direito securitário: seguros terrestres privados. São Paulo: Maltese, 1993.

FRANCO, Vera Helena de Mello; SZTAJN, Rachel. Direito Empresarial II - Sociedade anônima e mercado de valores mobiliários. São Paulo: Revista dos Tribunais, 2009.

GARRIGUES, Joaquim. Contrato de seguro terrestre. Madri: Imprenta Aguirre, 1979. 
GÓES, Wagner (coord). Fundos de pensão e um novo modelo de desenvolvimento in Papel dos fundos de pensão na formação da economia brasileira - Capitalismo social. São Paulo: ABRAPP / ICSS / SINDAP, 2007.

GRIFFI, Antonio Patroni; RICOLFI, Marco. Banche ed assicurazioni fra cooperazione e concorrenza. Milão: Giuffré, 1997.

HALPERÍN, ISAAC. Seguros, exposición crítica de la ley 17418. Buenos Aires, 1972.

HERMIDA, Tapia. Manual de Derecho de Seguros y Fondos de Pensiones. Navarra: Arazandi, 2006.

) Aspectos polémicos y novedosos del Seguro de Vida, in Documentos de Trabajo del Departamento de Derecho Mercantil, Universidad Complutense, março de 2006. Disponível em: 〈www.ucm.es/eprints>. Acesso em: 05/06/12

HOPE, Warren T. Introdução ao gerenciamento de riscos. Rio de Janeiro: FUNENSEG, 2002.

HOUAISS. Disponível em <http://houaiss.uol.com.br>. Acesso em 08/01/12.

INSTITUTO DE SEGUROS DE PORTUGAL. Conselho Directivo. A importância dos unit linked no ramo vida, 2003. Disponível em $<$ http://www.isp.pt/winlib/cgi/winlib.exe?skey=\&pesq=2\&doc=13818>. Acesso em 10/04/13.

JAMES, Estelle. Novos sistemas previdenciários: experiência, evidências e questões pendentes in A Economia Política da Reforma da Previdência. 1998. Disponível em <http://www.previdencia.gov.br/arquivos/office/3_081014-111356-651.pdf>. Acesso em $16 / 12 / 13$.

LAMBERT FAIVRE, Yvonne; LEVENEUR, Laurent. Droit des assurances, $13^{\mathrm{a}}$ ed. Paris: Dalloz, 2011. 
LEITE, Celso Barros. Conceito de Seguridade Social in Curso de Direito Previdenciário. Homenagem a Moacyr Velloso Cardoso de Oliveira [BALERA, Wagner (coord.), $5^{\mathrm{a}}$ ed. São Paulo: LTr, 2002.

LEITE, Francine. Envelhecimento populacional e a composição etária de beneficiários de planos de saúde. Disponível em:<http://www.iess.org.br/html/TDIESS00422011EnvelhecimentoFE.pdf>. Acesso em: 01/09/13.

LLORENS, Luís Latorre. Los límites entre la banca y el seguro en la comunidad económica europea. In Previsión y seguro. Madrid, nº 3, enero-febrero, 1990.

LOPES, Alexsandro Broedel; FURTADO, Cláudio Vilar. Private equity na carteira de investimentos das entidades de previdência privada. Revista de ContabIlidade e Finanças USP - Especial Atuária, São Paulo, v. 17, dez. 2006. Disponível em: $<$ http://www.scielo.br/scielo.php?script=sci_arttext\&pid=S1519$70772006000500009 \& \operatorname{lng}=$ pt\&nrm=iso $>$. Acesso em: 02/09/2013.

LOPEZ, Teresa Ancona; LEMOS, Patrícia Fraga Iglecias; RODRIGUES JUNIOR, Otavio Luiz. (coord.) Responsabilidade Civil na Sociedade de Risco in Sociedade de Risco e Direito Privado - desafios normativos, consumeristas e ambientais. São Paulo: Atlas, 2013.

LOWRY, John; RAWLINGS, Philip; MERKIN, Robert. Insurance Law. Doctrines and Principles. $3^{\mathrm{a}}$ ed. Oxford: Hart Publishing, 2011.

MACEDO JUNIOR, Ronaldo Porto. Qualificação jurídica dos fundos de previdência in Anais do II Fórum de Direito do Seguro “José Sollero Filho”. São Paulo: IBDS e Manuais Técnicos de Seguros, 2002.

MAGLIANO FILHO, Raymundo; SILVA, Sergio Luiz de Cerqueira. Fundos de pensão e um novo modelo de desenvolvimento in GÓES, Wagner (coord.). Papel dos fundos de pensão na formação da economia brasileira - Capitalismo social. São Paulo: ABRAPP / ICSS / SINDAP, 2007. 
MAESTRO MARTINEZ, José Luis. Provisiones matemáticas y rescates en el ROSSP. Disponível em: $<$ http://www.mapfre.com/documentacion/publico/i18n/catalogo_imagenes/grupo.cmd?path $=102830>$. Acesso em: 02/06/12.

(__ Nociones generales sobre el contrato de seguro in Previsión y seguro, $\mathrm{n}^{\mathrm{o}} 35$. Madrid, Abril, 1994.

MAGAllaneS, Pablo Medina. Anais do III Fórum de Direito do Seguro José Sollero Filho. São Paulo: Manuais Técnicos de Seguros, IBDS, 2003.

MANO, Cristina Cantanhede Amarante; FERREIRA, Paulo Pereira. Aspectos Atuariais $e$ Contábeis das Provisões Técnicas. Rio de Janeiro: Funenseg, 2009.

MARCHESINI, Lucas; RESENDE, Thiago. Previdência registra em janeiro maior déficit para mês desde 2009 . Disponível em: <http://www.valor.com.br/brasil/3042202/previdencia-registra-em-janeiro-maior-deficitpara-o-mes-desde-2009\#ixzz2YrrCFimI>. Acesso em: 01/07/13.

MARENSI, Voltaire. A nova lei da previdência complementar comentada. Porto Alegre: Síntese, 2001.

MARTINS, Sérgio Pinto. Direito da Seguridade Social. 21ª Ed. São Paulo: Atlas, 2004.

MELO, Eduardo Fraga Lima de; MELO, Mariana Arozo Benício de. Dilema da Conversão em Renda: Resgates Programados $\times$ Anuidade Vitalícia in Revista Brasileira de Risco e Seguros. v. 5, n. 9, abr./set. Rio de Janeiro: Funenseg, 2009.

MESSINA, Roberto Eiras. Lei da Previdência Complementar anotada. São Paulo: Saraiva, 2011.

MIRANDA, Pontes de. Tratado de Direito Privado. Campinas: Bookseller, 2006. 
NAZBERG, Sheila; IKEDA Marcelo. Previdência no Brasil: Desafios e Limites, Disponível em

http://www.bndespar.gov.br/SiteBNDES/export/sites/default/bndes_pt/Galerias/Arquivos/c onhecimento/livro/eco90_08.pdf>, acesso em 26/12/13.

NOGUEIRA, Rio. Benefícios previdenciais. Os isógonos e a ética securitária. Rio de Janeiro: STEA, 2002.

Reservas e Regimes Financeiros das Entidades Previdenciais. Rio de Janeiro: STEA, 2007.

OCDE, Organização para a Cooperação e Desenvolvimento Econômico. Private Pensions and Policy Responses to the Crisis, outubro de 2009. Disponível em <http://www.previdencia.gov.br//arquivos/office/3_090714-173205-002.pdf>. Acesso em 27/11/13.

OLIVEIRA, Francisco E. Barreto de; PASINATO, Maria Tereza de Marsillac; PEYNEAU, Fernanda Paes Leme. "Evolução recente do sistema de previdência complementar no Brasil e mercado potencial". Disponível em: <http://www.abep.nepo.unicamp.br/docs/anais/pdf/2000/Todos/evolu\%C3\%A7\%C3\%A3o $\% 20$ Recente $\% 20$ do\%20Sistema\%20de\%20Previd\%C3\%AAncia\%20Complementar....pdf: >. Acesso em: 05/01/2013.

ONLINE ETYMOLOGY DICTIONARY. Disponível em <http://www.etymonline.com >, acesso em 02/03/14.

PAGNUSSATT, Vinicius. Alianças estratégicas de bancos com seguradoras no Brasil: análise de cinco casos, dissertação de mestrado, programa de Pós Graduação em Administração da Universidade Federal do Rio Grande do Sul, Porto Alegre, 2010. Disponível em: <http://www.lume.ufrgs.br/bitstream/handle/10183/26498/000759470.pdf?sequence=1 > Acesso em: 15/06/12. 
PAIXÃO, Leonardo André. A previdência complementar fechada: uma visão geral. Disponível em: <http://www.previdencia.gov.br/arquivos/office/3_081014-111321983.pdf>. Acesso em: 12/11/13.

PIMENTEL, Fernando. "O papel social dos fundos de pensão (in Papel dos fundos de pensão na formação da economia brasileira - Capitalismo Social”. São Paulo: ABRAPP/ICSS/SINDAP, 2007.

PINTO, Vera Carvalho. Fundamentação filosófica do princípio do mutualismo nos contratos de seguro. Dissertação (Doutorado em Direito) - Pontifícia Universidade Católica de São Paulo, São Paulo, 2010. Disponível em: < http://www.dominiopublico.gov.br/download/teste/arqs/cp139588.pdf>. Acesso em: 05/08/13.

POLIDO, Walter. Contrato de seguro: novos paradigmas. São Paulo: Roncarati, 2010.

PÓVOAS, Manuel Soares. Previdência privada - Filosofia, Fundamentos Técnicos,

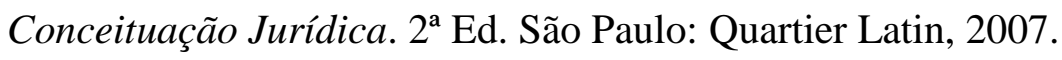

) Previdência Privada - planos empresariais, v. I. Rio de Janeiro: Fundação Escola Nacional de Seguros, 1991.

PREVIDÊNCIA SOCIAL. Histórico da previdência social. Disponível em <http://www.previdencia.gov.br/a-previdencia/historico/>. Acesso em 15/02/13.

PULINO, Daniel. Previdência Complementar - Natureza jurídico-constitucional e seu desenvolvimento pelas Entidades Fechadas. São Paulo: Conceito Editorial, 2011.

QUELHAS, Ana Paula. Seguros de Vida e Fundos de Pensão - uma perspectiva financeira e atuarial. Coimbra: Almedina, 2010.

R7. Brasileira tem um terço dos filhos da década de 1940, Disponível em: $<$ http://noticias.r7.com/brasil/noticias/brasileira-tem-um-terco-dos-filhos-da-decada-de1940-20121017.html>. Acesso em: 06/09/13. 
REIS, Adacir. (Org.) Fundos de pensão em debate. Brasília: Brasília Jurídica, 2002.

ROCOLFI, Marco. Assicurazione, credito e investimento. In Banche Ed assucurazioni fra cooperazione e concorrenza. Milão: Giuffrè, 1997.

RODRIGUES, Flavio Martins. Previdência complementar: conceitos e elementos jurídicos fundamentais. In Revista de Previdência da UERJ, n. 3. Rio de Janeiro: Gramma, 2005.

RODRIGUES, José Ângelo. Gestão de risco atuarial. São Paulo: Saraiva, 2008.

ROPPO, Vincenzo. Il Contratto. Milão: Giuffrè, 2001.

SÁ, Marina Célia Requejo de. Entidades abertas de previdência privada, avaliação atuarial, margem de solvência e provisões técnicas: um setor em pleno desenvolvimento. In Cadernos de Seguro. a. XXIV, n 123. Rio de Janeiro: FUNENSEG, mar. 2004.

SANTANDER. Previdência premiada. Disponível em $<$ http://www.santander.com.br/portal/wps/script/templates/GCMRequest.do?page=5793\&e ntryID=6617>, acesso em 01/12/13.

SANTOS, Jerônimo Jesus dos. Lei da Previdência Complementar Comentada. Rio de Janeiro: Editora e Livraria Jurídica, 2004.

SANTOS, Jonabio Barbosa dos; SANTOS, Morgana Sales da Costa. Família monoparental brasileira in Revista Jurídica, Brasília, v. 10, n. 92, p.5, out./2008 a jan./2009, disponível em <http://www.presidencia.gov.br/revistajuridica>. Acesso em $22 / 12 / 13$.

SANTOS, Jordanno Brunno Nicoletta dos. Desenvolvimento de métodos alternativos para avaliação de riscos segundo o conceito de supervisão baseada em riscos. 2011. Dissertação (Mestrado em Sistemas Eletrônicos) - Escola Politécnica, Universidade de São Paulo, São $\quad$ Paulo, $2011 . \quad$ Disponível em 
<http://www.teses.usp.br/teses/disponiveis/3/3142/tde-03042012-080226/>. Acesso em 05/01/14.

SARRES, Carolina. Déficit da Previdência ficou em $R \$ 42,3$ bilhões no ano passado. Disponível em <http://agenciabrasil.ebc.com.br/noticia/2013-01-30/deficit-da-previdenciaficou-em-r-423-bilhoes-no-ano-passado>. Acesso em 01/07/13.

SILVA, Fabiana Lopes da. Impacto do risco de longevidade em planos de previdência complementar. 2010. Tese (Doutorado em Controladoria e Contabilidade: Contabilidade) Faculdade de Economia, Administração e Contabilidade, Universidade de São Paulo, São Paulo, 2010. Disponível em <http://www.teses.usp.br/teses/disponiveis/12/12136/tde29112010-182036/>. Acesso em 12/11/12.

SILVA, João Calvão da. Banca Bolsa e Seguros. Coimbra: Almedina, 2007.

SILVA, Ovídio A. Baptista da. Natureza jurídica do "monte de previdência” in Anais do II Fórum de Direito do Seguro “José Sollero Filho”. São Paulo: IBDS e Manuais Técnicos de Seguros, 2002.

SINCOR-SP. Ranking das Seguradoras - $1^{o}$ Semestre/2012. Disponível em <http://www.ratingdeseguros.com.br/pdfs/rankbra0612.pdf >. Acesso em: 01/10/13.

SOARES, Antonio Carlos Otoni. Fundamento jurídico do contrato de seguro. São Paulo: Manuais Técnicos de Seguros, 1975.

STIGLITZ, Rubén S. Derecho de seguros. 4ª ed. Tomo I. Buenos Aires: La Ley, 2004.

SUPERINTENDÊNCIA NACIONAL DE PREVIDÊNCIA COMPLEMENTAR PREVIC, Estatística Trimestral, Junho 2013. Disponível em <http://www.previdencia.gov.br/arquivos/office/27_130918-144618-878.pdf>. Acesso em 26/12/13. 
SUPERINTENDÊNCIA NACIONAL DE SEGUROS PRIVADOS - SUSEP. História do seguro. Disponível em <http://www2.susep.gov.br/menususep/historiadoseguro.asp>. Acesso em 09/10/13.

TÔRRES, Renata. Déficit da Previdência é um mito, diz presidente da Anfip. Disponível em <http://www2.camara.leg.br/camaranoticias/noticias/ADMINISTRACAOPUBLICA/201168-DEFICIT-DA-PREVIDENCIA-E-UM-MITO,-DIZ-PRESIDENTEDA-ANFIP.html>. Acesso em 02/07/13.

TZIRULNIK, Ernesto. Regulação de Sinistro, São Paulo: Max Limonad, 2001.

TZIRULNIK, Ernesto; CAVALCANTI, Flávio de Queiroz Bezerra; PIMENTEL, Ayrton. O contrato de seguro de acordo com o Novo Código Civil Brasileiro. São Paulo: Revista dos Tribunais, 2003.

VARELLA, Marcelo Dias (Coord.). Responsabilidade e Socialização do Risco, p. 9. Disponível em <http:// www.estig.ipbeja.pt/ ac_direito/Varella2.pdf $>$. Acesso em 01/10/13.

VASQUES, José. Contrato de Seguro - Notas para uma teoria geral. Coimbra: Coimbra Editora, 1999.

VELlOSO, Andrei Pitten. Falacioso déficit da previdência social. Disponível em $<$ http://www.sindifisconacionalsp.org.br/UserFiles/File/Mat\%C3\%A9rias\%20de\%20Jornais/artigo_Previdencia.pdf>. Acesso em 05/07/13.

VENOSA, Silvio. Direito Civil: contratos em espécie, 13a ed. São Paulo: Atlas, 2013.

VERÇOSA, Haroldo Malheiros Duclerc. Curso de Direito Comercial. V. 4, T. I Fundamentos da Teoria Geral dos Contratos. São Paulo: Malheiros, 2011.

VIANNA, Maria Lucia Teixeira Werneck, Em torno do conceito de política social: 
notas introdutórias, $\quad$ disponível em http://www.enap.gov.br/downloads/ec43ea4fMariaLucia1.pdf>. Acesso em 22/12/13.

VILLELA, José Corrêa. Alguns pontos da "privatização" da previdência e da Lei Complementar $n^{o}$ 108/01 in CORREIA, Marcus Orione Gonçalves (coord.); VILLELA, José Corrêa (org.). Previdência Privada. Doutrina e Comentários à Lei Complementar $n^{o}$ 109/01. São Paulo: LTr, 2004.

WEINTRAUB, Arthur Bragança de Vasconcellos; VIANA, Bárbara Berbert Baer; LEVY, Dan Rodrigues; LEMOS, Thales. Peculiaridades dos programas de previdência privada e institutos obrigatórios. Disponível em: <http://revbprev.unifesp.br/index.php/edic/20dois/31-peculiaridades $>$. Acesso em 05/12/12.

WICKENDEN, Tony. The meaning of life insurance, Disponível em: <http://www.moneymarketing.co.uk/the-meaning-of-life-insurance/120077.article> . Acesso em 04/10/13.

WONG, Clarence; BARNSHAW, Mike; BEVERE, Lucia. Bancaseguros: tendencias emergentes, oportunidades e retos. Relatório Sigma n. 5/07. Disponível em: <http://media.swissre.com/documents/sigma5_2007_es.pdf>. Acesso em: 11/06/12. 